Portland State University

PDXScholar

Summer 9-18-2018

\title{
"The Battling Ground": Memory, Violence, and Resistance in Greenwood, North Tulsa, Oklahoma, 1907-1980
}

Greta Katherine Smith

Portland State University

Follow this and additional works at: https://pdxscholar.library.pdx.edu/open_access_etds

Part of the History Commons

Let us know how access to this document benefits you.

\section{Recommended Citation}

Smith, Greta Katherine, "'The Battling Ground": Memory, Violence, and Resistance in Greenwood, North Tulsa, Oklahoma, 1907-1980" (2018). Dissertations and Theses. Paper 4559.

https://doi.org/10.15760/etd.6444

This Thesis is brought to you for free and open access. It has been accepted for inclusion in Dissertations and Theses by an authorized administrator of PDXScholar. Please contact us if we can make this document more accessible: pdxscholar@pdx.edu. 
"The Battling Ground": Memory, Violence, and Resistance in Greenwood, North Tulsa, Oklahoma, 1907-1980.

\section{by}

Greta Katherine Smith

A thesis submitted in partial fulfillment of the requirements for the degree of

\section{Master of Arts}

in

History

\section{Thesis Committee: \\ Katrine Barber, Chair \\ Catherine McNeur \\ David Johnson \\ Karen Gibson}

Portland State University

2018 
(C) 2018 Greta Katherine Smith 


\begin{abstract}
Tulsa, Oklahoma's historically African American neighborhood of Greenwood in North Tulsa has long been contested terrain. Built by black settlers beginning in the late nineteenth-century, the neighborhood evolved into a vibrant community challenged by waves of violence - segregation at statehood in 1907, the Tulsa Race Riot of 1921, ongoing disinvestment, and processes of urban renewal beginning in the late $1950 \mathrm{~s}$ - that contributed to the erosion of the neighborhood and the eventual displacement of many area residents into remote housing projects further into North Tulsa. These waves of violence were propelled by Oklahoma lawmakers, local Tulsa government officials, members of the Ku Klux Klan, and private white citizens who worked to expand the city's color line by controlling the placement and visibility of black people in Tulsa and gain ownership of Greenwood — as the neighborhood was, and is, located on desirable land.
\end{abstract}

The people of Greenwood met these waves of violence with acts of resistance. They organized and lobbied against segregation at statehood, fought to save their community during the Tulsa Race Riot, and galvanized to rebuild almost immediately after. They maintained a culture of interdependence that contributed to strength in community and economy. Beginning in the late 1950s, they protested their displacement. However, by the late 1980 s, the ravages of slum clearance and expressway building had rendered much of Greenwood unlivable and many residents had no choice but to relocate. The loss of historic place and increased distance between community members made it difficult to maintain their shared identity and culture of interdependence. 
Taken altogether, these four waves of violence functioned as tools to carry out the city of Tulsa's longstanding agenda of reclaiming the prime urban real estate of Greenwood while broadening the area of land that segregated black \& white Tulsa. At the root existed white supremacy: the belief in the inherent superiority of the white race and its fundamental right to dominate society. 
To Tulsa. 


\section{Acknowledgements}

I saved writing this part for the last, because I have long had a swirling mass of ideas I envisioned writing - the people and sets of circumstances I wanted to acknowledge that helped move me to the position of extreme privilege I know that I embody in writing this thesis. I toyed with starting with my fourth-grade teacher, whose name I can no longer remember, but who understood the challenges I encountered every day in the classroom (even though I still cannot pinpoint them myself) and advocated for me. I wanted to move up through a litany of teachers and others who helped lift me up, including my high school art teacher Greg de Verges, who helped my dreams extend beyond the plains. I decided that would be too much, but I cannot help but to give a nod to them here.

As I put this thesis to bed, I am conflicted. I look forward to finishing, but in a way, I will miss it very much. To be able to focus so deeply on a subject is something that many people never get the chance to do and is something that I might never be able to do again. I hope I have done this subject justice here even though in my eyes it is far from finished. I am glad to move beyond my life as a student, but how I feel closing this chapter is something I do not know how to put into words. I will say that I feel beyond fortunate that people believed in me enough to support me in this effort.

I want to first thank Professor Katrine Barber for the unwavering support and guidance she has provided me with as my thesis advisor. Our conversations are the bedrock of this thesis. I first took a class with Dr. Barber during my first quarter at Portland State University. I had this crazy idea that I might like to go in to public history and have since taken countless classes with her as the professor, but I always think about 
that first one. In that class, I learned that to do this work you have to consider the realworld ramifications, and I struggled with paralysis where that is concerned. This is an ongoing struggle and Dr. Barber has gotten me over many of these humps. She has taught me to ask questions and to listen. That in knowledge lies responsibility—a responsibility to hear as well as to speak to certain truths - and that above all, you have to be brave. This has been the best lesson. Thank you, Dr. Barber.

I want to thank Eliza Canty Jones and Erin Brasell at the Oregon Historical Quarterly for choosing me to be the Rose Tucker Fellow for 2015-2017. I applied thinking I probably would not make the cut and began making other plans, but then they did choose me. Their decision is the only way I would have been able to go to graduate school. I would not be writing these words otherwise. I learned so much during my time there about writing, editing, and public history that I will not try to recount them here. I will just say that the Rose Tucker Fellowship was my favorite part about grad school.

Next, I want to thank the members of my thesis committee—Professor David Johnson, Professor Catherine McNeur, and Professor Karen Gibson. All of whom extended to me their support, guidance, and generosity of time. The lessons, conversations, and resources each of them provided me with helped to ground this work and encouraged me to get it done. I also want to thank the Portland State University History Department—Andrea Janda, Jeff Brown, and Professor Tim Garrison, in particular - for answering my often endless stream of questions as I navigated the program. I want to extend a special thank you to Dr. Garrison for providing me with funding to take a research trip to Tulsa during the summer of 2016. That trip helped me reconnect with the landscape and people that are the subject this thesis, as well as the 
chance to dive into the archives at Tulsa City-County Library, the University of Tulsa, and the Oklahoma State University-Tulsa. The people I was able to talk with and the materials I collected in visiting the archives are foundational components of this work.

I also want to acknowledge and express my deep appreciation for the Tulsa Race Riot scholars who did much of the work that I have built upon with this thesis. Thank you to Hannibal B. Johnson, Esq., of the 1921 Tulsa Race Riot Centennial Commission and Ray Pearcey of the Oklahoma Eagle for taking the time to talk with me when I was in Tulsa. Our conversations helped me to understand the history of Greenwood as well as my place in attempting to add my voice to the story as an outsider. One of the things Dr. Johnson said to me when we met at his office in Greenwood is something that I tried to hold at the center of this work. That is, first, not to try to tell the African American community in Tulsa what their history is, and second, that this story is not one that is special to Tulsa, but that it is repeated in black communities across the country. In writing this thesis, I have made it a priority to let the voices of the Greenwood community stand and tell their own story as much as possible. The interviews done in the 1990s by Eddie Faye Gates have proved an invaluable resource and I want to express my deep gratitude to Ms. Gates for her work both as an oral historian and as a scholar. Thank you also to University of Tulsa Archivist and Tulsa Race Riot historian, I. Marc Carlson for meeting with me and taking me on a driving tour of Tulsa Race Riot sites and to Dr. Scott Ellsworth for speaking with me over the phone when I was still an undergraduate and just beginning to grapple with this history. I also want to extend a special thank you to Michael Bates for communicating with me extensively through email and sharing resources. Our communication as well as Mr. Bates' work, in particular his article "Steps 
to Nowhere," was highly influential in this work and is, I believe, of great significance. Finally, I want to thank Lee Roy Chapman, who is no longer with us, but whose 2012 article "Nightmare in Dreamland," set my own inquiry in motion. Thank you, Lee Roy. When I was in junior high school, my mother made the decision to quit her soulcrushing job as an accountant for Citgo Petroleum and go back to school. It was a decision I found upsetting at the time, because it meant that we moved into one-room that we shared in her friend's suburban home outside Tulsa in Sand Springs, Oklahoma. This arrangement did not last long, and I moved in with my father about three months later, but my mother stuck it out. She told me to "hide and watch." At the age of 39 she earned her master's degree in speech pathology. Some twenty-odd years later, I find myself nearly the same age as she was and closing in on my own master's degree. I want to thank her for providing me with this example, as it made it a fairly easy decision for me to make once I arrived at a similar crossroads in life. Besides that, my mother has been an unflinching supporter all throughout my life, even when perhaps my behavior did not warrant such unwavering love. I cannot thank her enough or tell her how much this has meant to me. Though my parents divorced when I was 9, my father has been an everpresent source of love and support as well. He has listened to me during my moments of doubt and provided an editing-eye to countless papers, many of which I have integrated into this thesis. He was my research assistant in Tulsa and greasy-spoon diner companion. We've always bonded over chicken-fried steak, hot-dogs, television, and history. Both my parents entertained my thirst for stories from their life-experience as I was growing up, and I attribute much of my interest in history to their storytelling skills. And maybe a bit of my long-windedness as well. 
My greatest source of support all throughout my time as a student has without a doubt been my husband John. One of the biggest reasons I chose to go back to school in the first place was because I knew I needed to do something to keep up with his seemingly inexhaustible brain. Thank you, John, for staying up all hours talking with me about my thesis and everything else in the world and for comforting me when I was all "tears and hair." Having you to come home to and wake up with is what has kept me going through all of this.

I also want to thank my friends and other family members - especially my step mother, Iris, and step father, Martin — for their understanding and support. And a special thank you to my dog Frances, who I know cannot read and probably thinks of me as a giant porkchop, but who has been an ever-present comfort in my many times of need. She is my sentinel.

Last, I want to thank Tulsa. Tulsa is a place, but for me it is also a feeling. When last I was there in the summer of 2016, I had not been there for over ten years, and still the air found a certain equilibrium with my blood. Although I remember always feeling like an outsider during my time growing up there, being in Tulsa again felt like being home. Thank you, Tulsa, for your people, your unapologetically grease-laden food, your green-skies that are the harbinger of tornadoes, your fried-egg hot summer days that make for perfectly temperatured nights, and for your unfathomable inconsistencies, which I am still trying to understand. 


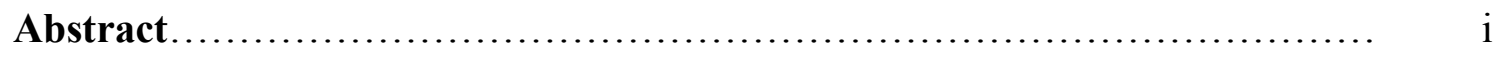

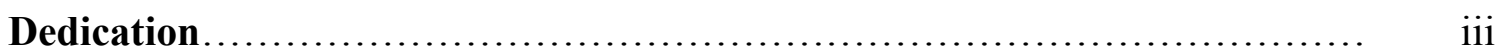

Acknowledgements................................................... iv

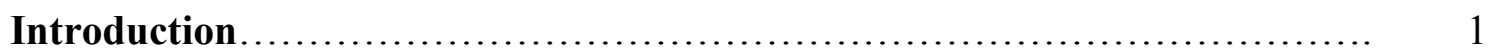

\section{Chapter One}

"Moving in the Air": The Settling of Greenwood, 1830-1921 ................. 17

\section{Chapter Two}

“Conspicuous Disorder”: Greenwood, May 30, 1921-September 28, $1921 \ldots \ldots \ldots .42$

\section{Chapter Three}

"Equally Strange and Hostile Places": Rebuilding to Relocation, 1921-1980s..... 84

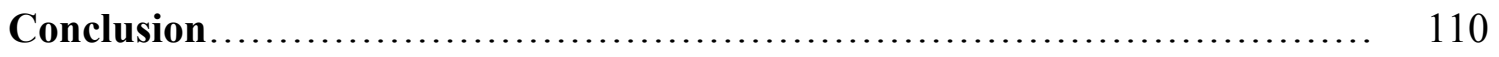

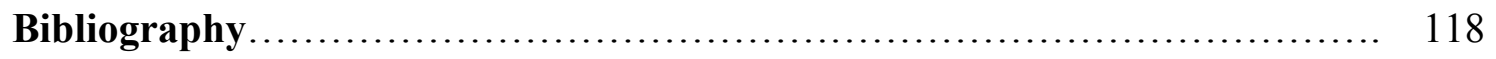

\section{Appendix}

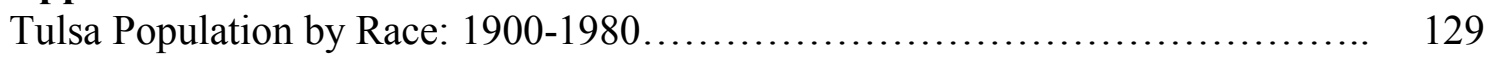

Tulsa Home Owners Loan Corporation Residential Security Map............... 130

Housing Projects in Relation to Historic Greenwood........................... 131 


\section{Introduction}

Just north of downtown Tulsa there is a vast empty area, about a half-mile long by a third of a mile wide... Superimposed on the empty, green space is a grid of seldom-used streets, each one paralleled by a pair of buckled or overgrown sidewalks, interrupted periodically by the stub of a driveway. Where there is a steep enough incline from the sidewalk to the middle of the block, there are sets of stone or concrete steps, leading up the rise to bare ground...The observer notes that this place is north of downtown and remembers that it was north of downtown in 1921 that a white mob invaded, looted, and burned an AfricanAmerican neighborhood to the ground...The land is an unbiased witness, but the steps and sidewalks tell us only that once there were homes here - not when they were built, what they looked like, when they went away, or why they went away. The regularity of the boundary and the thorough cleansing that took place within does not suggest the chaotic destruction of an inflamed mob. The land bears the mark of an officially planned and methodically executed purge. ${ }^{1} \sim$ Michael Bates

During my time as an undergraduate in history, I studied and wrote about legacies

of a particular violence in my home town, Tulsa, Oklahoma. This violence is what

Michal Bates is alluding to above: the Tulsa Race Riot of 1921 (TRR). What it took me a long time to realize, is that the TRR was not the only violence that occurred in North Tulsa, but that preceding and ensuing waves of violence-segregation, disinvestment, and processes of urban renewal — were similarly if not more devastating to the area and the people who lived there.

Growing up in South Tulsa we did not learn about the TRR in school and I did not have much occasion to travel into North Tulsa until I enrolled in the local alternative high school, a sort of "last chance" school, during my junior year. It was my last attempt at school and, if it did not work out, I planned to drop out. The school was born out of the Model Cities Program and located in North Tulsa where Model Cities Planners

${ }^{1}$ Michael Bates, "Steps to Nowhere," This Land Press, June 18, 2014, accessed November 15, 2015, http://thislandpress.com/2014/06/18/steps-to-nowhere/. 
anticipated that most of the student body would live. ${ }^{2}$ It was and is still called Project 12. My first time driving to school I was perplexed by what I perceived as a nonsensical landscape of beautiful but dilapidated brick buildings interspersed with swaths of cleared land and expressways. The residential neighborhoods were a patchwork of wellmaintained homes adjacent to vacant and boarded-up houses that lined crumbling roads with weeds sprouting up through potholes and cracks in the sidewalk. I swerved to avoid hitting the occasional dog laying on the sunbaked street.

I began asking people why North Tulsa was in such a state of disrepair and heard of a horrible race riot from which the community never recovered. I was also told that people in North Tulsa were too lazy to hold down jobs, that they did not know how to take care of their own properties, that they had no money of their own and lived off welfare. In other words, the primarily white people I asked believed that the conditions in North Tulsa were self-perpetuating and entirely the responsibility of the black Tulsans who lived there. They did not mention segregation beginning at statehood or how area residents rebuilt after the TRR, which destroyed the community's economic business center and much of their neighborhood — a place called Greenwood. No one spoke of the redlining or other discriminatory housing practices that almost entirely disinvested the area, making it nearly impossible for people to maintain their properties. No one

\footnotetext{
2 Passed by Congress in 1966, the federally funded Model Cities Program was an urban renewal initiative intended to mitigate damages done during earlier processes of urban renewal across the United States. Where earlier urban renewal initiatives employed bulldozers and wrecking balls as their tools in order to rid cities of blighted areas, the Model Cities Program focused more on forming collaborative relationships between community-based planning groups and Model Cities planners to improve, and not remove, problem areas within cities.
} 
acknowledged that North Tulsa was a food desert, how it lacked adequate bus lines, or how there was so little economic infrastructure that it was a wonder that anyone worked, because where would they $?^{3}$ No one talked about the racism or white supremacist tendencies that contributed to the disparity between North and South — black and whiteTulsa that allowed these conditions to happen in the first place. It took me seven years of studying this history to begin to understand it myself.

The past has a way of hanging around, at times leaving an imprint upon the landscape. Similarly, past events linger in a person's memory, whether or not they are spoken of out loud. As opposed to being solely relegated to our consciousness, memory and violence have a visceral component to them as well, which is embodied in the elements that make up the neighborhood - the streets, buildings, and topographical features. Memories of violence are often reactivated and transformed through physical engagement with particular places. ${ }^{4}$ Such is the case with Greenwood and greater North Tulsa, a place where past violences seem to persist.

Violence simultaneously annihilates memory and brings it into being. It has the same function for history. The destruction of lives and physical spaces creates a schism in collective memory, identity, and the historical record. ${ }^{5}$ While we often associate memory with certain events or time periods, "it is place that adds form to memories, and place is

\footnotetext{
3 “Economic Research Service," United States Department of Agriculture (USDA), updated May 18, 2017, accessed May 3, 2018, https://www.ers.usda.gov/dataproducts/food-access-research-atlas/go-to-the-atlas/.

${ }^{4}$ Margaret E. Farrar, "Amnesia, Nostalgia, and the Politics of Place Memory," Political Research Quarterly 64 (2011), 731.

${ }^{5}$ Karl Jacoby, Shadows at Dawn: An Apache Massacre and the Violence of History (New York, New York: Penguin Books, 2008), 3.
} 
what we associate memories most often with." "To those who know how to interpret it, the landscape is the richest historical record we possess - the physical link between what was and what has become. History, memory, and place act in concert with one another to shape the past. This process has a transformative effect on identity, as it is through the lived experience of interacting with a particular landscape that a person comes to understand their world and make their place in it. ${ }^{7}$ The history within a particular place is resonant throughout this interactive process. This contributes to the sometimes nebulous character of what we hold to be our historical truths. History is not a pure reflection of the past, but instead is most often curated, maintained, interpreted, and told by those who hold the most power. It is consequently employed by those in power to justify later acts of violence. History, as Karl Jacoby asserts, "is regularly invoked to justify new forms of domination and terror and is seldom about past violence alone, but violence in the present and future as well." ${ }^{8}$ Violence can take many forms. I define violence here not only as physical, but also as structural — bureaucratic, legislative, and economic. There is also violence inherent in omission - the controlling of the historic narrative to disclude earlier processes of violence. Greenwood in North Tulsa, Oklahoma, is one place where violence in its multitude of forms has played out upon the landscape. While the TRR and the resurgence of Greenwood are commemorated in the Black Wall Street Memorial, much of the neighborhood exists today as a testament to the denial of a history of violence, destruction, and dispossession for North Tulsa and its residents. Violence

\footnotetext{
${ }^{6}$ Farrar, "Amnesia, Nostalgia, and the Politics of Place Memory," 725.

${ }^{7}$ Ibid, 731.

${ }^{8}$ Jacoby, Shadows at Dawn, 6.
} 
lingers there in the scars of foundations and vacant lots where buildings or homes once stood. The place, in its very 'feeling,' is an unbiased witness to the lives and events from the past. ${ }^{9}$

African Americans first arrived in the Indian Territory as slaves. ${ }^{10}$ Once emancipated, freed-slaves - many of whom migrated from the South hoping to escape the hostile racial climate — established all-black towns and started a movement to make the territory an all-black state. ${ }^{11}$ But with Oklahoma statehood in 1907 came discriminatory legislation such as Senate Bill Number One, which ushered in a period of Jim Crow segregation. ${ }^{12}$ After statehood, many African Americans described Oklahoma as being much like the places in the South they sought to leave behind.

In 1909, the City of Tulsa annexed Greenwood, but neglected to provide the allblack enclave with basic city services. ${ }^{13}$ Still, the population of Greenwood grew as African Americans continued to migrate to Tulsa, which was by then touted as the oil capital of the world. They too would capitalize on the money brought by tapping the oil rich land. Because segregation limited their population to the confines of an area

\footnotetext{
${ }^{9}$ U.S. Department of the Interior, National Park Service, Final 1921 Tulsa Race Riot Reconnaissance Survey (November 2005), 98. Feeling, as described in this survey, is defined as being "a property's expression of the aesthetic or historic sense of a particular period of time." The report found that the 1921 Tulsa Race Riot area expresses a high degree of "feeling." This area includes historic Greenwood and Mount Zion Baptist Church.

${ }^{10}$ Hannibal Johnson, Black Wall Street: From Riot to Renaissance in Tulsa's Historic Greenwood District (Fort Worth, Texas: Eakin Press, 1998, Kindle edition), Kindle location numbers 106-114.

${ }^{11}$ Ibid, locs. 151-165.

12 James Hirsch, Riot and Remembrance: The Tulsa Race War and Its Legacy (Boston, Massachusetts: Houghton Mifflin, 2002, Kindle edition), Kindle location numbers 40204030.

${ }^{13}$ Hirsch, Riot and Remembrance, loc. 582.
} 
consisting of four-square miles, the district suffered from overcrowding, dilapidated housing, and unsanitary conditions throughout most of the residential areas. ${ }^{14}$ Despite these limitations, Greenwood's foundational components of business, education, religion, and people contributed to a pride of place and a culture of interdependence. Community leaders A.J. Smitherman and J.B. Stradford advocated for the people of Greenwood and worked alongside returning black WWI veterans to galvanize a united front against a rising tide of racially motivated hostility emerging throughout Oklahoma.

In 1921, an angry mob consisting of private white citizens, members of the Tulsa Police Force, and members of the Ku Klux Klan, among others, burned many of the homes and buildings in Greenwood, murdering upwards of 300 people in the process. ${ }^{15}$ While black veterans and private citizens put up a good fight, in the end they were outgunned and outnumbered. Local newspaper reporting cultivated the impulse to destroy Tulsa's all-black district while local government agents, members of the Ku Klux Klan, and influential white citizens facilitated the violence of the Tulsa Race Riot. ${ }^{16}$ In the following week, many of these same people tried to permanently displace Greenwood residents by attempting to pass a prohibitive zoning ordinance. The citizens of

\footnotetext{
14 Ibid, loc. 583 .

15 The official count of the dead has long been disputed by private citizens, scholars, and official reports. The Department of Health's Bureau of Vital Statistics put the number at 36 - ten whites and 26 blacks. The official Red Cross report's count rang in at 300. The Oklahoma Commission to Study the Tulsa Race Riot concluded in 2001 that the number of deaths attributed to the TRR cannot be determined and ranges from 175 to 300. Don Ross, et al., Tulsa Race Riot: A Report by the Oklahoma Commission to Study the Tulsa Race Riot of 1921, Oklahoma Commission to Study the Tulsa Race Riot of 1921, 2001, 123-124, accessed May 5, 2018, http://www.okhistory.org/research/forms/freport.pdf; Loren L. Gill, "The Tulsa Race Riot" (Master's Thesis, The University of Tulsa, 1946), 45-46.

${ }^{16}$ Commission to Study the Tulsa Race Riot of 1921, Tulsa Race Riot, 123.
} 
Greenwood defeated the zoning ordinance and were able to rebuild, however a lack of monetary remunerations for the destruction of the TRR coupled with the mainstays of segregation and fractured race relations took an economic toll.

The rapidity with which African Americans were able to rebuild after the destruction of the TRR and the attempted land grab by Tulsa city planners earned Greenwood a nationwide reputation of being a place and a people that were not to be conquered. The continuity that Greenwood residents were able to foster by remaining in their historic home enabled them to maintain community ties and look out for one another, but the economic devastation that followed the violence of the TRR is something that reverberated within Tulsa's black community for generations to come. In the ensuing decades, Greenwood and North Tulsa, like many other black neighborhoods in cities across America, underwent an economic decline that not only served to wreck the physical structures of the neighborhood, but also took a considerable toll on the community. By the mid-twentieth century, they faced disinvestment, and processes of urban renewal—slum clearance, expressway building, and remote housing projectswhich finally achieved the goal of displacing Tulsa's African American citizens from their close-in historic neighborhood and economic business center, splintering the residents into less visible pockets of community further into the city's north. Like segregation at statehood and the TRR, at the root of disinvestment and processes of urban renewal existed white supremacy: the belief in the inherent superiority of the white race and its fundamental right to dominate society. In Tulsa, this meant controlling the placement and visibility of black people. 
Most scholars of Greenwood have described segregation, the violence of the TRR, disinvestment, and processes of urban renewal as distinct, but related entities. In her 1997 book They Came Searching: How Blacks Sought the Promised Land in Tulsa, Eddie Faye Gates uses oral histories of early black Oklahoma pioneers to recount their aims, hopes, and ambitions in coming to Tulsa where they managed, despite rigid segregation and both overt and covert discrimination, to carve out meaningful lives in their new "Promised Land"_-Tulsa. ${ }^{17}$ I also draw from Gates's 2003 book, Riot on Greenwood: The Total Destruction of Black Wall Street, 1921, to gain insight into the roots of public memory about the TRR from an African American perspective. ${ }^{18} \mathrm{Scott}$ Ellsworth's study of the Tulsa Race Riots, Death in a Promised Land (1982), details events in Tulsa between 1917 and 1921, suggesting that contradictions in the memories of black and white Tulsans_—what he calls "segregated memory"—reflects different biases and concepts of history and remains as a legacy of the segregation era. ${ }^{19}$ Hannibal Johnson's 1998 book Black Wall Street: From Riot to Renaissance in Tulsa's Historic Greenwood District traces the history of Greenwood where black pioneers settled and built a vibrant and complex community, revived it from ruins after the Tulsa Race Riot, and are undergoing current efforts of revitalization. ${ }^{20}$ Riot and Remembrance, by James Hirsch, focuses on the continuing ramifications of the TRR as descendants of survivors

\footnotetext{
${ }^{17}$ Eddie Faye Gates, They Came Searching: How Blacks Sought the Promised Land in Tulsa (Austin, Texas: Eakin Press, 1997).

${ }^{18}$ Eddie Faye Gates, Riot on Greenwood: The Total Destruction of Black Wall Street, 1921 (Fort Worth, TX: Eakin Press, 2003).

${ }^{19}$ Scott Ellsworth, Death in a Promised Land: The Tulsa Race Riot of 1921 (Baton Rouge: Louisiana State University Press, 1982, Kindle edition).

${ }^{20}$ Johnson, Black Wall Street.
} 
fight for belated retribution. ${ }^{21}$ Hirsch places special emphasis on the events following the TRR, including attempts to rebuild Greenwood as well as looking at how Tulsa sought to come to terms with the TRR. Alfred L. Brophy, in his 2002 book, Reconstructing the Dreamland: The Tulsa Riot of 1921: Race, Reparations, and Reconciliation, argues that, since the TRR was government assisted, the victims as well as their descendants are entitled to restitution, something they were most recently denied by the United States Supreme Court in 2003. ${ }^{22}$

Building upon the framework of these and other scholars, I employ themes of persistent and wave-like violence and the vagrancies of memory to argue for a new interpretation: current conditions in North Tulsa of poverty, crime, food insecurity, and blight are the product of a longer historical development. From 1907 through the mid1980s, violence in North Tulsa came in four waves with no discrete beginning or end. One violent period reaches its apex, crescendos, washes over into another, and rolls on. The first wave of violence was discriminatory legislation passed by white Oklahoma lawmakers once the Twin Territories became a state in 1907. The second was the burning out of African Americans by whites, many of whom were Klansmen, during the Tulsa Race Riot in 1921. The third wave began immediately after the TRR when the City of Tulsa and insurance companies refused to help Greenwood residents pay for rebuilding costs, taking the form of disinvestment: an economic and social freezing out of blacks by

${ }^{21}$ Hirsch, Riot and Remembrance.

${ }^{22}$ Alfred L. Brophy, Reconstructing the Dreamland: The Tulsa Riot of 1921: Race, Reparations, and Reconciliation (Oxford: Oxford University Press, 2002, Kindle edition); James DeWolfe Perry, "Reparations for the Tulsa Race Riot of 1921," Tracing Center, last modified January 7, 2013, http://www.tracingcenter.org/blog/2013/01/reparations-for-the-tulsa-race-riot-of-1921/. 
Tulsa City Officials. They achieved this through refusing loans or extending social services that would help African Americans rebuild and later maintain their properties.

Historical omissions, disinvestment, and neglect continued for decades between 1907 and the 1980s and contributed to conditions of poverty and blight within North Tulsa. The fourth wave of violence occurred when Tulsa City Planners employed the destructive processes of urban renewal, beginning in the late 1950s, to clean up what they and many other whites perceived as the blighted area of North Tulsa. In so doing they forever altered the landscape and displaced many North Tulsa residents. Taken altogether, these four waves of violence wore away at the buildings, homes, and people of Greenwood, eroding their history and disrupting their continuity and lifeways. These waves of violence - segregation at statehood, the TRR, disinvestment, and processes of urban renewal—functioned as tools to carry out the city of Tulsa's longstanding agenda of reclaiming the prime urban real estate of Greenwood and displacing its residents to less visible areas further to the north of the city. ${ }^{23}$

${ }^{23}$ While scholarship about the TRR is robust, in writing this thesis I hope to contribute in the following ways. First, I situate the TRR within a broader historical context using the waves of violence framework. In so doing, I show that the TRR was not an isolated incident, but instead was part of a longer historical process. This framework also allows me to show how each wave of violence-segregation at statehood, the TRR, disinvestment, and urban renewal - fed into and contributed to the exponential growth of the others, which are all legacies of white supremacy. They build upon each other and reverberate into the present. Second, I separate the TRR into four acts - the Riot, the Battle, the Massacre, and the Land Grab - in order to highlight the tactics and agendas of those involved. It is my hope that drawing these distinctions will one day help in gaining reparations for TRR survivors and their descendants, as the U.S. Supreme Court denial in 2003 was predicated upon the argument that the city of Tulsa was responsible for neither the destruction of Greenwood nor the economic devastation that followed. I believe separating the TRR into these four acts helps us to look closely at the actors and outcomes and, in so doing, illuminates that the city of Tulsa was indeed responsible. Third, I highlight the culture of interdependence that was and is critical to black success 
Thinking about violence as waves helps us to visualize the relentless and amorphous nature of violence in Tulsa, but it is not meant to attribute this violence to acts of nature and strip people of their responsibility. To the contrary, looking at the actors and motivations behind these waves of violence and their aftereffects as well as acts of resistance counters years of historical omissions and revisions. In so doing, this framework helps to shed light upon a history of racially motivated violence in Tulsa. It shows us that, antithetical to the notion of blacks in Tulsa not being successful—that they did not ever manage to carve out a strong economy, own property, or rebuild and recover from the destruction of the TRR - that they were, in fact, successful in all these things. It also shows us how the real, long-term success of the white rioters was that their racist attitudes and ideals lived on, embedded within the ideologies of certain white Tulsans who enacted them through later processes of disinvestment and urban renewal. It demonstrates how black Tulsans responded with acts of similarly relentless and successful acts of resistance. Greenwood and North Tulsa are a locus point where history and memory converge. ${ }^{24}$

and organized resistance in Tulsa. I also show how displacement destroyed the closeness of proximity that enabled the culture of interdependence to thrive. Fourth, and finally, by talking about my own relationship to this history, I make a case for how the omission of much of this history from the primary historical narrative has affected present day race relations in Tulsa between the African American citizenry in the North and the whites, like myself, in South Tulsa. This part of the story illustrates how the color line is still being maintained in both physical spaces as well as public memory.

${ }^{24}$ Alessandro Portelli, The Order Has Been Carried Out: History, Memory, and Meaning of a Nazi Massacre in Rome (New York: Palgrave Macmillan, 2003). This book influenced much of my thinking about the relationship between history, memory, mythmaking, and place in Tulsa. 
It is difficult to separate myth from reality in the history of Greenwood as contradictions abound between the recollections of black and white Tulsans as well as within primary and secondary source materials. Accounts of Greenwood as told by whites exist in newspapers and government reports. These sources describe the conditions of vice and blight in lurid detail —of the brothels, speakeasies, and "houses in conspicuous disorder," that were in apparent abundance. Greenwood, claims one newspaper article in the summer of 1921, was a "menace to the overall health of the city." The white community called Greenwood "Little Africa," "Darkytown," or worse. The African American community called it "Negro Wall Street" or "Black Wall Street."25 Blacks remember Black Wall Street as an enviable neighborhood. It was equivalent to, as one organizer of the National Negro Business League (NNBL) called it, "a regular Monte Carlo." ${ }^{26}$

Secondary scholarship has sometimes been dismissive of the "Black Wall Street" moniker, arguing that it does not accurately reflect the less savory aspects of Greenwood that existed in the residential areas outside the main business district. Historian James Hirsch claims the name "is more ironic than apt" because, he argues, "it is unlikely that any black Tulsans traded stocks or bonds in the first quarter of the twentieth century. ${ }^{27} \mathrm{I}$ believe Mr. Hirsch misunderstands the meaning behind the name "Black Wall Street." It was not so literal as to imply the same scale of economic activity as Wall Street, but was instead intended to reflect and advertise the economic opportunity for African Americans

\footnotetext{
${ }^{25}$ Robin Walker, The Rise and Fall of Black Wall Street (Reklaw Education, 2010, Kindle edition), Kindle location 92.

${ }^{26}$ Ibid.

${ }^{27}$ Hirsch, Riot and Remembrance, locs. 670-671.
} 
who lived in Greenwood — because they were doing well for themselves. That is not to say that everything was perfect in Greenwood. There was poverty and vice as well as fine homes and strength in community. It was never as simple as one or the other. As former Greenwood resident Eunice Cloman Jackson recalls, "Greenwood was always wild."28 Reconciling conflicting memories and perceptions of Greenwood has been a difficult task. In fact, I think that there is no reconciling them. Instead, I choose to let them stand. Conflicting memories and perceptions of Greenwood—what Ellsworth calls "segregated memory" - elucidates the racial discord within the city of Tulsa. ${ }^{29}$ This is the root of a history of violence and resistance in Tulsa — white and black. Joseph Amato, in his book Rethinking Home, asserts that local history is important because it "satisfies an innate human desire to be connected to a place" and to people of the past. ${ }^{30}$ It can also tempt nostalgia. ${ }^{31}$ It is important that I avoid reinforcing a frozen, glorified, or mythologized image of the past, and this is not always easy. Many of my sources, which are oral history interviews with people taken years after much of the history my thesis deals with has occurred, are with people who look back upon their time in Greenwood with a fondness that is imbued with sentimentality. Many of the interviewees were witness to the horrors of the TRR. Many were also displaced by urban renewal. Their memories, as Alessandro Portelli asserts, are historical fact, and myths are "not necessarily a wrong narrative, but... a narrative that you cannot give up because you built

${ }^{28}$ Gates, They Came Searching, 267.

${ }^{29}$ Ellsworth, Death in a Promised Land, loc. 1632.

${ }^{30}$ Joseph Amato, Rethinking Home: A Case for Writing Local History (University of California Press, 2002, Kindle edition), Kindle location 104.

${ }^{31}$ Ibid. 
your whole sense of personal, political, national identity upon that story. And if you give up that story, then you have to rethink everything." 32 Predetermined conclusions and alternative narratives are used to back up and defend historical myths. The memories of TRR survivors and North Tulsa residents are their own and I do not try here to refute them, rather I want to highlight their voices while situating them within my own historical analysis.

Historical mythmaking with the story of Greenwood and the waves of violence that whittled away at their neighborhood and community shows also how motivations and processes of violence are not frozen in time, but instead continue to invade the present and affect the people of Tulsa - particularly African Americans - in many ways. This violence is a mainstay of white supremacy and has long been used to maintain the racial status quo in Tulsa and many other American cities.

In chapter one, I trace the roots of Greenwood from the initial arrival of blacks in Oklahoma to the settling of Greenwood. In so doing, I will show the challenges faced by the community as well as their persistence as they forged a place for themselves in the increasingly hostile racial climate of segregation. I will also show how white Oklahomans and Tulsans hindered the efforts of the Greenwood community through discriminatory laws, neglect in providing basic infrastructure, and social services. I argue that these acts were prompted by racially motivated fears held by many whites at the presence of a large African American population within the city and that these acts were

\footnotetext{
32 Alessandro Portelli, "Myth, Memory, and Trauma: Intergenerational Transmission of Stories of the Fosse Ardeatine Massacre in Rome," Filmed lecture for Columbia University's Oral History Master of Arts Program, June 12, 2017, https://www.youtube.com/watch? $v=\mathrm{cmK} 3$ ScrE5eI\&t=1022s.
} 
the first in a series of waves of violence intended to harden the color line by removing black Tulsans from the close-in area of Greenwood to more distant and less visible areas further from the city center.

Chapter two involves a detailed history of the Tulsa Race Riot of 1921 (TRR) and its immediate aftermath. While this event is referred to most often as the Tulsa Race Riot, I argue that this is too simplistic of a name. Historian and University of Tulsa archivist Marc Carlson asserts that the TRR was split into two events: the violence at the courthouse, he argues, was the "Riot" while the white mob that pursued black Tulsans into Greenwood was a "Pogrom." ${ }^{33}$ Greenwood community members, TRR survivors, and scholars more often refer to the entire event as a "holocaust" or "massacre." ${ }^{44}$ While I agree with this distinction in terminology, I argue that the TRR, as a whole, was a violence in four acts. First came the "riot" which was the initial clash at the courthouse. But, before the "massacre," as I've chosen to call it, there was a second act: the "battle," where black and white Tulsans engaged in armed combat—and the blacks won. Act three was the "massacre," leaving upwards of 300 people dead and the neighborhood in ruins. The fourth and last act was the "land grab." Distinguishing between these four acts

${ }^{33}$ I. Marc Carlson, "The Tulsa Race Riot of 1921," (Bachelor's Thesis, Oklahoma State University, 1989), accessed on May 13,2018, https://tulsaraceriot.wordpress.com/research-topics/tulsa-race-riot-of-1921-paper/. When I visited Tulsa on a research trip in June of 2016, Mr. Carlson took me on a driving tour of TRR sites. This is when I first heard about this distinction in terminology. Mr. Carlson was kind enough to grant me permission to record this tour which took place on Monday, June 13, 2016. Recording held by author.

${ }^{34}$ Buck Colbert Franklin, My Life and an Era: The Autobiography of Buck Colbert Franklin (Louisiana State University Press, 1997), 201; Don Thompson, Hush, Somebody's Callin' My Name: A Photographic Essay of Survival, Resilience and Perseverance (Tulsa, Oklahoma: Holbrook Printing Company, 2008), 62. 
illuminates how the TRR was not a spontaneous "riot," as Tulsa city officials later claimed, but that it was in fact a sustained and organized attack on Tulsa's African American citizenry—who were occupying valuable land. Taken altogether, these four acts amounted to the TRR, which I also call the "Riot" with a capital "R." The TRR is the second wave of violence whites perpetrated against blacks in Tulsa. This second wave was intended to remove African Americans from the close-in area of Greenwood to more distant and less visible areas outside of city limits.

In chapter three we look at the third and fourth waves of violence that devastated Greenwood: disinvestment and urban renewal. The third wave was disinvestment that manifested not only in a lack of monetary remunerations for the destruction of the Riot, but also in long-term government sanctioned exclusionary lending and real estate practices. This third wave is difficult to distinguish from the others as it has always been there for black Americans, however here I focus on the refusal of the City of Tulsa to help the residents of Greenwood in rebuilding efforts after the Riot, the unwillingness of banks to grant any black person a loan, and the nationwide practice of redlining. This disinvestment contributed to the neighborhood's economic and physical deterioration and the fourth wave of violence, processes of urban renewal—slum clearance, expressway building, and urban renewal housing projects - which began in the late 1950s, bit at the heels of the ravages of community disinvestment. These third and fourth waves of violence achieved Tulsa city planner's longstanding goal of displacing Tulsa's African American citizens from their close-in historic neighborhood and economic business center, fracturing their community and moving them further into the city's north. 


\section{Chapter One \\ "Moving in the Air": The Settling of Greenwood, 1830-1921}

\section{Introduction: The First Wave of Violence}

Black settlement in Oklahoma came in two movements. In the first, enslaved blacks were forcibly marched along with their Native masters on the Trail of Tears to the Oklahoma Indian Territory. The second movement followed the Civil War and the ending of Reconstruction in 1877, when freed blacks migrated to Oklahoma seeking to leave behind the southern customs of their former slaveholders. In this later period of settlement, African Americans formed all-black towns with the goal of establishing Oklahoma as an all-black state. Between 1865 and 1920, freed blacks established thirtytwo all-black towns in America. Former slaves and freedmen settled twenty-eight of these black townships within the Twin Territories. The movement to make Oklahoma an all-black state ended in 1907 when Oklahoma become the $46^{\text {th }}$ state admitted into the Union. Now, Oklahoma belonged to the South. The first law white lawmakers passed ushered in segregation. This was the first wave of violence for African Americans in Oklahoma. ${ }^{35}$

${ }^{35}$ Jimmie Lewis Franklin, "African Americans," The Encyclopedia of Oklahoma History and Culture, accessed February 12, 2018, http://www.okhistory.org/publications/enc/entry.php?entry=AF003,; Larry O'Dell, "AllBlack Towns," The Encyclopedia of Oklahoma History and Culture, accessed February 12, 2018, http://www.okhistory.org/publications/enc/entry.php?entry=AL009; Gates, They Came Searching; Ralph Ellison, Going to the Territory (New York: Random House, 1986); and Jimmie Lewis Franklin, Journey Toward Hope: A History of Blacks in Oklahoma (Norman: University of Oklahoma Press, 1982). The history of black settlement in Oklahoma is interwoven through much of the TRR scholarship as well. 


\section{Black Settlement in Oklahoma: "A Healthy Contagion"}

Black settlement in Oklahoma is linked with Indian removal beginning in the 1830s, when the federal government forced members of the Five Civilized Tribes - the Cherokee, Chickasaw, Choctaw, Creek, and the Seminole - to leave their territorial homelands in the Southeast and relocate to Indian Territory—present day Oklahoma. When whites forcibly marched tribal members to their assigned lands on the Trail of Tears, Indians brought their black slaves with them. After the abolishment of slavery in 1865, freed slaves in the Indian Territory_or Freedmen — received allotments of land and became members of the different tribes through intermarriage with tribal members. ${ }^{36}$

In 1833, the Lower Creek Indians of the Alabama settlement of Tallasi were forced to relocate to Oklahoma in the area that is present day Tulsa. The Lower Creeks carried the ashes from the last council fire held in their ancestral homelands on their forced march to Oklahoma, deposited them under a large oak tree, and named their new home Tallasi, which translates to "Old Town." The name Tulsa came from a shortened pronunciation of Tallasi and was originally "Tulsey" or "Tulsee.",37

\footnotetext{
${ }^{36}$ Franklin, "African Americans."

${ }^{37}$ Carl E. Gregory, "Tulsa," The Encyclopedia of Oklahoma History and Culture, accessed February 12, 2018, http://www.okhistory.org/publications/enc/entry.php?entry=TU003; "What is the meaning of the name 'Tulsa'?" Local/Municipal Government: Tulsa Area FAQs, Tulsa County Library, accessed January 5, 2018, http://guides.tulsalibrary.org/c.php?g=695427\&p=4931218\#9395804; “Tulsa and Oklahoma History in the Research Center: Tulsa Timeline," Tulsa County Library, accessed January 5, 2018, http://guides.tulsalibrary.org/c.php?g=695416\&p=4931569.
} 
In 1889, President Harrison made a section of the Indian Territory called the Unassigned Lands available for resettlement. ${ }^{38}$ Whites and free blacks, many of whom left the South after Reconstruction officially ended in 1877 , began to migrate and settle new homes in the Indian Territory. ${ }^{39}$ In 1890, the U.S. Congress declared the western half of the Indian Territory, Oklahoma Territory. Thereafter the two territories became known as the Twin Territories. ${ }^{40}$

Free blacks saw the Twin Territories as a "Promised Land."41 There they could escape from the political, economic, and social oppression southern lawmakers institutionalized through the passing of racist legislation and southern whites upheld through increasingly prevalent acts of extralegal violence in the wake of the Civil War. In the Territories, African Americans could own land and exercise their right of selfdetermination, which they sought to accomplish by settling all-black towns. Kinship networks linked all-black towns such as Langston, Rentiesville, and Homer with Native land holders and black Freedmen. ${ }^{42}$

By the mid-1880s repressive conditions for black people in the South had reached acute proportions and "Oklahoma Fever" was in full swing. African Americans migrated

\footnotetext{
38 Stan Hoig, "Land Run of 1889," The Encyclopedia of Oklahoma History and Culture, accessed January 2, 2018, http://www.okhistory.org/publications/enc/entry.php?entry=LA014.

39 Jimmie Lewis Franklin, The Blacks in Oklahoma (Norman: University of Oklahoma Press, 1980), 4-5; Franklin, "African Americans."

${ }^{40}$ Hirsch, Riot and Remembrance, loc. 489.

${ }^{41}$ Gates, They Came Searching, 31.

${ }^{42}$ Gates, They Came Searching, xi; Martin Dann, "From Sodom to the Promised Land:

E.P. McCabe and the Movement for Oklahoma Colonizaton," Kansas Historical

Quarterly, Vol. XL, No. 3 (Autumn 1974), accessed March 21, 2018, http://www.kancoll.org/khq/1974/74 3 dann.htm.
} 
to the Territories with greater intensity from the deeper parts of the South, setting up allblack, self-reliant communities and townships. These towns became sanctuaries from the racial discrimination and violence found in mixed-race towns throughout the American South, where they could enjoy economic security and mutual protection. ${ }^{43}$ The first was the town of Langston, established in 1890 and propelled by the vision of Edwin McCabe. ${ }^{44}$

Born in Troy, New York, McCabe moved to the predominantly black town of Nicodemus, Kansas, in $1878 .{ }^{45}$ There the citizens elected him as the settlement's secretary. Later that year they appointed him to the position of county clerk. ${ }^{46} \mathrm{McCabe}$ rose in the ranks of the Republican party and, in 1880, party members selected him as their Kansas delegate-at-large at the Chicago convention of the Republican party. However, later that same year the Kansas State Convention of Colored Men accused McCabe of selling out in caucus. After that, McCabe left Kansas for the Twin Territories. He participated in the 1889 Land Run, secured a land claim, and began working to establish Oklahoma as an all-black state. ${ }^{47}$

Once in the Territories, McCabe established the first weekly African American newspaper, the Langston City Herald, in May of 1891. The newspaper had a readership base that encompassed the southern states of Arkansas, Kansas, Louisiana, Florida, Texas, and Missouri, among others, and was a crucial element in blacks migrating to and

${ }^{43}$ Franklin, "All-Black Towns."

${ }^{44}$ Dann, "From Sodom to the Promised Land."

45 Ibid.

46 Dann, "From Sodom to the Promised Land."

${ }^{47}$ Ibid.; "Edward P. McCabe," Kansapedia, Kansas Historical Society, accessed March 21, 2018, https://www.kshs.org/kansapedia/edward-p-mccabe/12142. 
settling in Oklahoma. ${ }^{48}$ The pages of the paper advertised Oklahoma as a mecca for African Americans who sought to better their lives, enticing them with the prospect of wealth through property ownership while offering guidance for securing an Oklahoma homestead. One article entitled: "HOME, SWEET HOME" estimated that roughly onethousand "colored families" had secured homesteads in Oklahoma "through the influence of the Herald," and, through the acquisition of land, had amassed collective wealth amounting to "two-hundred-and-fifty thousand to four-hundred-thousand dollars." 49 McCabe cited this as evidence of what blacks migrating to Oklahoma could expect for the future. However, many who migrated to Oklahoma came without enough money or provisions and, as a result, were disillusioned, reportedly suffering "terrible conditions, almost starving." ${ }^{, 0}$ McCabe warned that they should "Come prepared, or not at all," cautioning that only those with the means to do so should move to the Territories as they would need to be able to sustain themselves for at least one year. ${ }^{51}$ The benefits, assured McCabe, would certainly outweigh the hardships, as once established, "Oklahoma — the future land and the paradise of Eden and the Garden of the Gods," would be a sanctuary for blacks where they could "rest from mob law [and] be secure from every ill of the

\footnotetext{
48 "About the Langston City Herald (Langston City, O.T. [Okla]), 1891-1902," Chronicling America: Historic American Newspapers, Library of Congress, accessed March 21, 2018, http://chroniclingamerica.loc.gov/lccn/sn83025050/. 49 "HOME, SWEET HOME: Home for you and your Children. MILLIONS! Of Acres in the Cherokee Strip Soon to be Given to the People for Homes," Langston City Herald, November 17, 1892, 2, https://www.newspapers.com/image/78174955/?terms=what $\% 2 B w i l l \% 2 B y o u \% 2 B b e \% 2$ Bif\%2Byou\%2Bstay\%2Bin\%2Bthe\%2BSouth. 50 “HOME, SWEET HOME," Langston City Herald, 2. ${ }^{51}$ Ibid.
} 
southern policies." ${ }^{52}$ Promoting the effort towards securing Oklahoma as an all-black state, McCabe urged African American migrants to enter into the Promised Land with their eyes wide open, "in order that you may meet and successfully overcome the hardships of a new country, and in order that the race here may make the highest possible development in the shortest possible space of time." ${ }^{, 3}$ A New York Times article from this same year details how those who came unprepared were sustained by their "more fortunate brothers, and some way they will be kept alive until summer when they will show that they are self-sustaining for they will work and exist upon almost nothing." ${ }^{\prime 54}$

This is the origin of a culture of interdependence among black Oklahomans. It is an aspect of community life that people maintained throughout all-black towns and enclaves until later waves of violence made community ties more difficult to maintain. But, in the early days of African American settlement, this culture of interdependence was crucial to the success of black migration and the establishment of all-black, selfreliant communities and towns. It was also essential for blacks who lived in towns where whites also lived.

McCabe anticipated that, by 1893, the African American population in the Territories would reach over one-hundred thousand and that, by that time, blacks in Oklahoma would "secure control of political affairs [...], be able to dictate the policy of this territory or state, [and] have a Negro state governed by Negroes. ${ }^{" 55}$ Of the possibility

${ }^{52}$ Topeka Call, April 24, 1891, Quoted in Dann, "From Sodom to the Promised Land." 53 "HOME, SWEET HOME," Langston City Herald, 2.

54 "The Blacks in Oklahoma," New York Times, April 9, 1891, accessed March 21, 2018, https://www.newspapers.com/image/20345010/?terms $=\% 22$ black\%2BMecca $\% 22$.

${ }^{55}$ American Citizen, October 23, 1891. Quoted in Dann, "From Sodom to the Promised Land." 
of whites also settling in the territories McCabe stated that "We do not wish to antagonize the whites. They are necessary in the development of a new country, but they owe my race homes, and my race owes to itself a governmental control of those homes." ${ }^{\prime 56}$

Whites in the territories were not so diplomatic. To the movement for all-black statehood, many responded with threats of physical violence. One Republican is noted as saying, "I am told that dead niggers make an excellent fertilizer, and if the negroes try to Africanize Oklahoma, they will find that we will enrich our soil with them." ${ }^{57}$ Another white Oklahoman, upon learning that McCabe was seeking the appointment of state governor, stated that if he succeeded, he "would not give five cents for his life." 58

An 1891 New York Times article called this a "War of Races with Plows and Hoes in Prospect" asserting that "almost every train brings in negroes from the South, who remain. Agents from Georgia and Arkansas have in vain sought to induce some of these blacks to return as laborers. They will not go. They send glowing accounts back to their friends of the new land, and the stream of immigrants constantly increases." ${ }^{, 59}$ Black migration to the Oklahoma Territories became a sort of healthy contagion, "moving in the air, in the parlor, on the lawn and almost causes whole families to move in sympathy." ${ }^{60}$ Enticed by stories they heard from friends and family members as well as booster literature found in publications like Sturm 's Statehood Magazine that bore headlines such

\footnotetext{
56 Ibid.

${ }^{57}$ Jere W. Robertson, "Edward P. McCabe And The Langston Experiment," The Chronicles of Oklahoma (Oklahoma Historical Society, 1973), 346.

${ }^{58}$ Ibid.

59 "The Blacks in Oklahoma," New York Times. 60 "Oklahoma and Indian Territory," Langston City Herald, October 5, 1895, 2, accessed March 22, 2018, https://www.newspapers.com/image/78136159.
} 
as "Tulsa, the Future Metropolis," many settled in Tulsa on the banks of the Arkansas River. ${ }^{61}$

Both whites and African Americans migrated to Tulsa from areas primarily in the South. While both groups shared a common goal of making a new start, many whites brought with them the southern customs and attitudes that blacks sought to leave behind. By 1882, the arrival of the St. Louis and San Francisco railroad - popularly known as the "Frisco" railroad—established Tulsa as a city, and by 1890 approximately 1,000 people were living there. ${ }^{62}$

\section{Settling Greenwood: North of the Frisco Railroad}

In 1899, John the Baptist arrived in Tulsa. ${ }^{63}$ A former slave from Kentucky, John the Baptist's father's name was Julius Caesar. Their master had named them both after religious and classical characters - a common practice of the time. ${ }^{64}$ One day, during the height of the Civil War, Julius outsmarted the slave-owner by forging his master's signature on a pass and escaping to Stratford, Ontario. He took the name of his sanctuary city for his own, changed the "T" to a "D," and became J.C. Stradford. In Ontario, J.C. worked, saved up money, and eventually was able to return to Kentucky and obtain legal

\footnotetext{
61 “Tulsa, the Future Metropolis," Sturm's Statehood Magazine, Vol. 1, No. 1 (September 1905), 7, https://dc.library.okstate.edu/digital/collection/EOS/id/1366/rec/10.

${ }^{62}$ Augustus J. Veenendaal Jr., "St. Louis and San Francisco Railway," The Encyclopedia of Oklahoma History and Culture, accessed March 28, 2018, http://www.okhistory.org/publications/enc/entry.php?entry=ST009; See "Tulsa Population by Race 1900-1980" table in appendix for population citation.

${ }^{63}$ Hirsch, Riot and Remembrance, loc. 420.

64 "Slave Trade in Louisiana: Naming Practices," Whitney Plantation, accessed February 15, 2018, http://whitneyplantation.com/naming-practices.html; Hirsch, Riot and Remembrance, loc. 424.
} 
papers that designated him and his family free. His son, John the Baptist—now J.B.

Stradford — went on to earn his law degree at Indiana University and, at 39 years of age, became one of Greenwood's most prominent community leaders, boosters, and activists. ${ }^{65}$ Believing that African Americans would be stronger if they banded together, J.B. Stradford purchased large parcels of land north of the Frisco railroad tracks, which bordered Tulsa's downtown, and developed them himself or resold them to other African Americans. ${ }^{66}$

Just after the turn of the twentieth century, the discovery of oil in the Territories enticed more people to move there. In the summer of 1901, four miles west of Tulsa, the first "real gusher" of oil was discovered at Red Fork. It was called the "Sue Bland," named for the part-Creek Indian wife of Dr. J.C Bland, one of the owners of the oil well. Then, in 1905, oil was discovered at the Glenn Pools, just four miles south of town and the oil-boom was on. The oil extraction industry became the life-blood of the state and Tulsa was the seat of the oil industry. Both blacks and whites moved to Tulsa with greater frequency after the oil-boom. ${ }^{67}$ Among them was O.W. Gurley, a wealthy African American land-owner, educator, and entrepreneur. Gurley came to the Territories from Arkansas during the Oklahoma Land Run of 1889, but did not move to Tulsa until 1905. ${ }^{68}$ Gurley opened a grocery store in Deep Greenwood and, like Stradford, bought forty-acres of land north of the Frisco railroad line. ${ }^{69}$ After having his land platted,

${ }^{65}$ Steve Gerkin, "First Charged, Last Freed," This Land Press, March 20, 2014, http://thislandpress.com/2014/03/20/first-charged-last-freed/.

${ }^{66}$ Ibid; Hirsch, Riot and Remembrance, kindle location 424.

${ }^{67}$ Gates, They Came Searching, 33.

${ }^{68}$ Johnson, Black Wall Street, loc. 289.

69 Ibid. 
Gurley sold plots “to colored" people exclusively. By 1906 Stradford and Gurley's tracks of land had a name: Greenwood..$^{70}$

The following year on November 16, 1907, the Twin Territories became the State of Oklahoma-a Southern state. ${ }^{71}$ With Oklahoma statehood came the first wave of violence: segregation and Jim Crow laws. This brought an end to any illusions of the possibility of Oklahoma becoming an all-black state, as African Americans witnessed the racial climate deteriorate to familiar levels of the places many of them had left behind.

\section{Oklahoma Statehood: Jim Crow Claims the Territories}

A system of laws and racist customs enforced by the attitudes, rules, and physical violence of white people, Jim Crow laws were meant to uphold the white power structure by keeping blacks and whites physically separated through segregation in public spaces. These racist laws were named for a black character from a popular 1832 song. ${ }^{72}$

Before Oklahoma statehood, Jim Crow and segregation had not been present in the Territories. Prominent Greenwood community leader, Buck Colbert Franklin, recalled in his memoirs that "In the beginning, there was no segregation or apparently any thought of segregating the races" within the city of Tulsa. Blacks and whites "lived together and

\footnotetext{
70 “O.W. Gurley: The Visionary Builder,” Black Wall Street, USA, accessed May 11, 2018, http://www.blackwallstreet.org/owgurly.

71 “Oklahoma Statehood, November 16, 1907," National Archives, Center for Legislative Archives, Featured Congressional Documents, accessed May 11, 2018, https://www.archives.gov/legislative/features/oklahoma.

72 "Jim Crow Laws and Racial Segregation," VCU Libraries Social Welfare History Project, Virginia Commonwealth University, accessed January 3, 2018, https://socialwelfare.library.vcu.edu/eras/civil-war-reconstruction/jim-crow-lawsandracial-segregation/.
} 
were buried together." ${ }^{, 73}$ A lawyer by trade, Franklin remembered a black law office as well as a black-owned and operated barbershop, real estate office, and "a rooming house patronized by both races" on the corner of Archer and Cincinnati in Downtown Tulsa. ${ }^{74}$ Franklin attributed these relative good relations between African American and white Tulsans to the fact that in pre-statehood Oklahoma, "Indians and Freedmen owned most, if not all, of the land" and the federal government was not concerned with "the separation of the races."75 "On the surface at least," wrote Franklin, "no one thought anything about it." ${ }^{\prime 76}$ The discovery of rich veins of oil under the red-clay earth changed all of that.

Movements towards Oklahoma statehood followed closely on the heels of the discovery of oil and began in earnest around the turn of the twentieth-century. White settlers hoped to gain control of the anointed soil of the Twin Territories through statehood and, in 1907, Oklahoma became the $46^{\text {th }}$ state in the Union. ${ }^{77}$ Upon achieving statehood, the first piece of legislation passed by white lawmakers was Senate Bill Number One, which prohibited blacks in Oklahoma from traveling, living, and marrying outside of their race. ${ }^{78}$ When voters ratified the state constitution later that same year, they passed laws that legislated segregation, disallowed black voting rights, and cemented southern racist beliefs and customs into law. ${ }^{79}$ This was the first wave of violence.

${ }^{73}$ Franklin, My Life and an Era, 199.

${ }^{74}$ Ibid, 200.

${ }^{75}$ Franklin, My Life and an Era, 200.

76 Ibid.

77 David R. Morgan, Oklahoma Politics \& Policies: Governing the Sooner State (University of Nebraska Press, 1991), 4.

78 Ibid, 25.

${ }^{79}$ Ibid, 75. Hirsch, Riot and Remembrance, loc. 4022. 
African Americans living in Oklahoma and surrounding states mobilized to fight Jim Crow laws. In December of 1907 a group of "several hundred" black people from Oklahoma and Kansas held a meeting in Coffeyville, Kansas where they worked to raise funds to hire an attorney to fight the passage of discriminatory laws in Oklahoma, declaring Jim Crow as being "unjust and an imposition to the negro race." ${ }^{\prime 0}$ The Oklahoma Supreme Court upheld Jim Crow laws, saying they were "demanded by all the people of the state. ${ }^{" 11}$ Despite the better efforts of blacks from Oklahoma—who clearly did not "demand" Jim Crow laws, but also apparently did not count amongst the "people of the state"- and neighboring states, Jim Crow laws remained in effect in Oklahoma for over fifty years. ${ }^{82}$

By1910, Tulsa had annexed Greenwood, absorbing it into the city. ${ }^{83}$ The Greenwood area began at the intersection of Greenwood and Archer, spanning from the Frisco railroad tracks in the south northwards to Pine Street, and east to west from the Midland Valley railroad tracks to Detroit Avenue. The entire area encompassed about four square miles. Greenwood's population continued to grow even as the boundaries of their designated living area remained the same. By 1910, Greenwood's population was 2,754, making Tulsa's total African American population 7.87 percent and rising. ${ }^{84}$

White Tulsans resented the presence of the Greenwood community and did not like that the city had such a large and growing black population. A headlining article in

\footnotetext{
80 “JIM CROW IS UNJUST,” Muskogee Times-Democrat, December 27, 1907.

${ }^{81}$ Ibid.

${ }^{82}$ Hirsch, Riot and Remembrance, loc. 623.

${ }^{83} \mathrm{Ibid}$, loc. 582.

${ }^{84} \mathrm{Ibid}$, loc. 585.
} 
the April 12, 1912 issue of the Tulsa Democrat asked, "Shall Tulsa Be Muskogeeized?"85 A little town located about fifty-miles southeast of Tulsa, Muskogee, Oklahoma had a sizable African American population at the time and its own black-owned and operated newspaper called the Muskogee Star, the owner and editor of which was Andrus J. (A.J.) Smitherman. ${ }^{86}$ The Tulsa Democrat article concluded that "Tulsa appears now to be in danger of losing its prestige as the whitest town in Oklahoma." 87 After a Democratic win in a local election later that month, the paper published another article stating that the city would now be able to "continue to advertise to the world that it is a white man's town, where white men rule and predominate." 88 These articles illustrate how white Tulsans considered whiteness as a point of pride and sought to keep their town predominantly white through the segregation, disenfranchisement, and the exclusion of black citizens. Whites had growing anxieties about the existence of an all-black enclave within the city, as Greenwood was itself more populated than most other towns in Oklahoma by 1912. The following year in 1913, A.J. Smitherman moved to Tulsa from Muskogee. He brought his newspaper operation with him and renamed it the Tulsa Star. Along with J.B. Stradford, Smitherman would become one of Greenwood's most important community leaders and activists. ${ }^{89}$

85 “SHALL TULSA BE MUSKOGEEIZED?” Tulsa Democrat, April 12, 1912, quoted in Hirsch, Riot and Remembrance, loc. 588.

${ }^{86}$ Johnson, Black Wall Street, loc. 1048.

87 “SHALL TULSA BE MUSKOGEEIZED?" quoted in Hirsch, Riot and Remembrance, loc. 588.

${ }^{88}$ Ibid, loc. 588.

${ }^{89}$ Johnson, Black Wall Street, loc. 1046. 
After statehood Tulsa became, in essence, two towns. Whites worked and resided in South Tulsa, where downtown was situated. African Americans lived solely in North Tulsa, in the community of Greenwood. A popular saying went: "Tulsa is the oil capital of the world, but the negro had neither oil nor capital." ${ }^{90}$ However, many blacks worked in South Tulsa where they were able to capitalize on the high wages provided by white, oil-rich Tulsans. Working as cooks, maids, porters, janitors, and in a host of other professions largely in the service sector, they took the money they earned in the white part of town and spent it where they lived-in Greenwood. ${ }^{91}$ An unintended consequence of segregation in Tulsa was that the arrangement served well to fuel Greenwood's economy and contributed to the strength of the community by further fostering an already evident culture of interdependence..$^{92}$

\section{Cornerstones of Community}

Economy, religion, education, and people were the cornerstones on which Greenwood stood. The first two blocks of the neighborhood were called Deep Greenwood - a prosperous business district and the seat of the district's economic, cultural, and social center. African American churches such as Vernon AME and Mt. Zion Baptist Church served as important community gathering spaces and children in Greenwood went to school where they lived - their classmates were their neighbors. Black people in Greenwood all lived within close proximity to one another, enabling

${ }^{90}$ Hirsch, Riot and Remembrance, loc. 684.

${ }^{91}$ Ibid, loc. 686.

92 Johnson, Black Wall Street, locs. 1841-1846. 
them to band together for mutual protection and support as they had done during prestatehood days. The conditions under which most people in Greenwood lived, however, were less than ideal. Greenwood, like its bordering areas on the outer edges of Downtown Tulsa, had problems of vice including gambling, sex work, and the production and sale of illegal drugs and alcohol. ${ }^{93}$

In Greenwood, business and community were intertwined. This is because, in a town where whites forbid African Americans from patronizing their businesses in South Tulsa, the merchants in Greenwood provided services and access to goods that black Tulsan's were unable to get elsewhere. ${ }^{94}$ Much like other successful communities, Greenwood had economic diversity among its residents. Born in 1907, Wilhelmina Guess Howell grew up in Greenwood. She recalled the web of relations that composed the landscape of her youth-her father's law office and uncle's doctor's office that both existed on Greenwood Avenue alongside the work-places of other black professionals such as ministers, dentists, real estate agents, merchants, the middle class, and poor. Because of this diversified and insular-by-necessity economy, Greenwood developed a thriving, self-sustaining community and a reputation for being a place where African Americans could support one another and prosper together. It was a community vibrant. ${ }^{95}$

\footnotetext{
${ }^{93}$ For more on pre-Riot Greenwood, see: Ellsworth, Death in a Promised Land; Johnson, Black Wall Street; Gates, They Came Searching; and Walker, The Rise and Fall of Black Wall Street.

${ }^{94}$ Johnson, Black Wall Street, loc. 233.

95 Wilhelmina Guess Howell interviewed by Eddie Faye Gates in Gates, They Came Searching, 113.
} 
More and more blacks chose Greenwood as their new home. Among them was the Little family of Boley, Oklahoma who moved to Tulsa in $1913 .{ }^{96}$ Mabel B. Little was 17 years old at the time and recalled her impression that "black businesses flourished" in Deep Greenwood. ${ }^{97}$ There existed theatres with glittering marquees (one of which was named the "Dreamland"), dance halls, grocery stores, drug stores, and restaurants. Little remembers one restaurant in particular, Huff's Cafe on Archer Street, as being, "a thriving meeting place in the black community. You could go there almost anytime, and just about everybody who was anybody would be there." 98 The preponderance of shops and businesses in Deep Greenwood were owned and patronized by people who lived in North Tulsa's surrounding residential neighborhoods.

People came from their residences to Deep Greenwood for the usual goods and services - a Coca-Cola on a hot day, food, entertainment - but people also came to sit and visit, while others came for help filling out paperwork or to seek assistance in getting proper medical care. Jobie Elizabeth Holderness remembered the store she owned with her husband in Greenwood as "a place where black people in the community knew they could come to for help. It was a sort of a community social service agency." 99 The Mann brothers owned a grocery store - the largest in Tulsa employing five butchers. Wife of M.M. Mann, Augusta Mann, remembered "The grocery business was different in the old days. At that time people really cared about each other. There was especially a fondness

${ }^{96}$ Johnson, Black Wall Street, loc. 326.

${ }^{97}$ Mabel B. Little quoted in Johnson, Black Wall Street, loc. 326.

${ }^{98}$ Ibid.

99 Jobie Elizabeth Holderness interviewed by Eddie Faye Gates in Gates, They Came Searching, 106. 
for children in the community. It was like children belonged to the entire community, not just their parents. Everyone looked after the children in the neighborhood." ${ }^{\prime 100}$ The economic center of Deep Greenwood not only filled people's pockets, but also provided important gathering spaces where people could socialize and seek support within the allblack enclave.

In addition to a successful and diversified business district, education was another foundational component of the Greenwood community. With Oklahoma statehood came segregated schools and mandatory attendance for both black and white students. ${ }^{101}$ African American school children took their lessons in a two-room, wooden building that was located between Cameron and Easton streets on Hartford Avenue. Built in 1908, the schoolhouse served grades one through eight. By 1910, Tulsa county possessed the second lowest black illiteracy rate of all the counties in Oklahoma and over three-quarters of Tulsa's black, school-aged children attended school. ${ }^{102}$

In 1913, an eighteen-room brick building and a four-room, wood-frame building on the corner of Elgin Avenue and Easton Street replaced the old schoolhouse. The larger building was Dunbar Grade School while the smaller one was the first iteration of Booker

\footnotetext{
${ }^{100}$ Augusta Mann Gates interviewed by Eddie Faye Gates in Gates, They Came Searching, 149.

${ }^{101}$ Leonard B. Cayton, "A History of Black Public Education in Oklahoma," (PhD diss., University of Oklahoma, 1977), https://shareok.org/bitstream/handle/11244/4326/7732851.PDF?sequence=1; Walker, The Rise and Fall of Black Wall Street, loc. 125.

${ }^{102}$ Ibid.; Hirsch, Riot and Remembrance, loc. 747; Walker, The Rise and Fall of Black Wall Street, loc. 125.
} 
T. Washington High School, it's first class consisting of fourteen students. ${ }^{103}$ The curriculum consisted of English; arithmetic, including algebra, commercial arithmetic, geometry, trigonometry, and physics; American, ancient, medieval, and modern history; a variety of music and art classes; vocational training; science; typing; civics; and athletics. $^{104}$

The first principal of Booker T. Washington High School was E.W. Woods. Originally from Louisiana, Woods heard that Greenwood was in urgent need of black teachers. Compared to other professionals such as doctors and lawyers whose clients were typically poor, educators earned more money and were even more highly regarded in the Greenwood community. ${ }^{105}$ Woods held the position as principal for thirty-five years. During his tenure, he promoted education, leadership, and responsibility. In 1919 the high school relocated to a two-story building on Haskell Street where the Principal Woods famously told the students, "You're as good as ninety-nine percent of the people and better than the rest." Many of his students took his words to heart. ${ }^{106}$

Like many African American communities, Greenwood was church-centered with the relationship between the community and the church an intimate one. Similar to other black churches in Greenwood and throughout the United States, Mount Zion Baptist Church was a "nation within a nation" where congregants could exercise rights, such as

\footnotetext{
103 “Booker T. Washington High School (Tulsa)," World Heritage Encyclopedia, accessed February 17, 2018, http://newspaperslibrary.org/articles/eng/Booker_T. Washington_High_School_(Tulsa). ${ }^{104}$ Walker, The Rise and Fall of Black Wall Street, locs. 134-138.

105 Hirsch, Riot and Remembrance, loc. 747. 106 Ibid.
} 
voting, that they were otherwise denied. In addition to providing religious instruction, Mount Zion functioned as its own community in which its congregants could learn about their world. ${ }^{107}$

Established in 1909 in a one-room, wood framed school building, what would later become Mount Zion Baptist Church was first named Second Baptist Church as the majority of its congregation were former members of the First Baptist Church. However, not liking the association of being second to anything, the members decided to rechristen their church "Mount Zion." ${ }^{108}$ Hard times befell the congregation and, in 1914, members were forced to vacate the school on three days' notice. Church records do not say why they were evicted, but describe this time as "the first series of dark days." 109 The congregation relocated to a former dance hall on North Greenwood Avenue and, soon after, were able to build a simple wood framed, white-washed structure they called the Tabernacle on Elgin Street. The Tabernacle was meant to be temporary as they planned to build a permanent house of worship on adjacent land. ${ }^{110}$

In 1916, construction of the intended permanent home of Mount Zion Baptist Church began. Congregants raised $\$ 42,000$ towards building the church and secured a $\$ 50,000$ loan from a private lender for the rest. Five years after construction began, congregants dedicated the church on April 4, 1921. The majestic three-story brick gothic

\footnotetext{
${ }^{107}$ Michele M. SimmsParris, "What Does it Mean to See a Black Church Burning? Understanding the Significance of Constitutionalizing Hate Speech," University of Pennsylvania Journal of Constitutional Law (Spring 1998): 134.

108 Johnson, Black Wall Street, locs. 1406-1411.

${ }^{109}$ Hirsch, Riot and Remembrance, loc. 737.

${ }^{110}$ U.S. Department of the Interior, National Park Service, National Register of Historic Places Form: Mount Zion Baptist Church, Section 8 Page 7.
} 
structure of the new Mount Zion Baptist church stood as a symbol of determination and growing affluence of the congregation and the larger community of Greenwood.

Community residents were proud of this impressive structure and believed that it was as good as, if not superior to, any white church in Tulsa. ${ }^{111}$

In the climate of separation and exclusion in which African American churches were born, the sermons and fellowship experienced by congregants became rooted within the souls of their communities - a source of black empowerment. ${ }^{112}$ However, the more involved a black church's preachers and congregants became in speaking out against the racial intolerance and violence that proliferated in the early twentieth century, the more they were chastised by the white majority, the churches themselves becoming targets of racial terrorism. ${ }^{113}$

While Mount Zion was a place of religious worship and refuge from the outside world, it also battled injustice. The Reverend F.K. White, who served as pastor in 1913 and 1914, rebuked white churches during his sermons stating, "Not one in a thousand will speak out in our defense." 114 He admonished the hypocrisy of white ministers who, in speaking against imperialism and the poor treatment of immigrants, had ignored the gross mistreatment and racialized violence perpetuated against blacks. Pastor White predicted that one day, God would intervene. ${ }^{115}$

${ }^{111}$ Hirsch, Riot and Remembrance, loc. 760.

112 SimmsParris, "Black Church Burning," 137.

113 Ibid, 138.

${ }^{114}$ Hirsch, Riot and Remembrance, loc. 748.

115 Ibid. 


\section{Housing in Greenwood}

While Greenwood possessed strong cornerstones of business, education, religion, and community, this was less so the case for the residential areas that branched north from Deep Greenwood. Large brick homes and bungalows that housed Greenwood's elite existed on the two or so blocks closest to Greenwood's bustling business district, while most of the rest of the people in Greenwood lived in small cottages, shacks, structures built out of packing crates, dilapidated barns, or tents. ${ }^{116}$

The City of Tulsa was slow to provide basic infrastructure such as garbage, sewage lines, and paved roads even in white areas of town, but when it came to Greenwood they neglected to provide these services altogether. Much of the housing in Greenwood was crowded and impoverished with unsanitary conditions, as indoorplumbing — even sewage connections - were scarce. In a 1920 report, the Colored Public Health Nurse of Tulsa wrote that one outdoor toilet was shared by eight houses — and one of those houses had eleven rooms. Only six blocks of Greenwood's streets were paved and on the ditch-lined, dirt roads of the remaining twenty-nine blocks, cows, chickens, dogs, and other animals roamed freely. ${ }^{117}$ Another report written that same year by the American Association of Social Workers stated that while the report painted "a rather dismal picture, the colored community has very outstanding assets—its people." ${ }^{118}$ By 1920, Greenwood's population had reached 10,903, which meant that Tulsa's total African American population had grown from 7.87 to 10 percent, making Greenwood

\footnotetext{
116 Ibid, loc. 678.

${ }^{117}$ Hirsch, Riot and Remembrance, locs. 671-776.

118 Ibid, loc. 681.
} 
larger than most towns in Oklahoma. ${ }^{119}$ This population growth struck white Tulsans at the core of their racially motivated intolerance and anxieties. Additionally, there existed on the outer borders of Downtown Tulsa, the area surrounding the Frisco railroad, and in Greenwood rooming houses that were known places of gambling, sex work, alcohol, and illegal drugs. Eunice Cloman Jackson remembered that, "When Mama used to bring us kids up to Tulsa $[\ldots]$ we'd come by train. The conductor always announced the Greenwood stop (at the corner of Archer) with a little song:

\section{All out for Tush hog town, Greenwood Street, the battling \\ Ground! $!^{120}$}

Vice in Tulsa existed primarily on the borders - the outer edges of town and the areas between downtown and Greenwood on First Street and near the Frisco railroad depot. Rooming houses were sites around which much of the vice activity in Tulsa revolved. These existed in Greenwood as well. In a 1921 Report on Vice Conditions in Tulsa, agents reported visiting rooming houses in Greenwood as well as other areas of Tulsa, where they gambled, procured booze, and the company of women. Influential Tulsans - both black and white—owned a number of these houses. Among them were O.W. Gurley in Greenwood and Tate Brady, a white Tulsan who was instrumental in bringing the Ku Klux Klan into the city. The report noted that much of the vice activity occurred under the noses of Tulsa policemen, who turned a blind eye. The agents who wrote this report appeared less concerned with the illegal activities of those they

\footnotetext{
119 Ibid, loc. 586.

${ }^{120}$ Eunice Cloman Jackson interviewed by Eddie Faye Gates in Gates, They Came Searching, 117.
} 
encountered in their undercover work and were more focused on looking into the role of the Tulsa Police Force in the prevalence of vice within the city. ${ }^{121}$

\section{Activism in Greenwood}

In the climate of Jim Crow, Oklahoma towns_-including Tulsa and the enclave of Greenwood - were no stranger to white-vigilante justice and mob-violence. Racialized violence was a statewide phenomenon that politicians, business leaders, and law enforcement gave quiet blessing to even, at times, helping to facilitate extralegal violence such as lynchings. ${ }^{122}$ Community leaders in Greenwood worked to foster self-defense and protect not only the citizens of Greenwood, but also the lives of African Americans throughout the state. In the pages of the Tulsa Star, A.J. Smitherman promoted ideals of self-reliance and organized action as a safeguard against the undertow of racism and the ever-present threat of white-vigilante justice. ${ }^{123}$

Smitherman and J.B. Stradford travelled separately and together to help stop white-on-black violence in towns all over Oklahoma. In 1917, a white mob burned down twenty black-owned homes in Dewey, Oklahoma - a small town about 50 miles north of Tulsa. Smitherman travelled to Dewey to investigate the event and reported his findings

\footnotetext{
121 "Report on Vice Conditions in Tulsa, 1921 May 18," Box 25, Record Group 1-2, State of Oklahoma vs. John A. Gustafson, Chief of Police Tulsa (Tulsa Race Riot Investigation Vice Condition); Civil Case No. 1062, Attorney General, Oklahoma State Archives Division, Oklahoma Department of Libraries, Oklahoma City, OK.

${ }^{122}$ Scott Ellsworth calls this Tulsa's "Vigilante Tradition." Ellsworth, Death in a Promised Land, locs. 1663-1673.

${ }^{123}$ Gerkin, "First Charged, Last Freed,"; Larry O'Dell, "Andrew J. Smitherman, the Tulsa Star, and the Tulsa Race Riot of 1921," The Chronicles of Oklahoma (Fall 2002). The offices of the Tulsa Star were located at 501 North Greenwood Street.
} 
to the Governor of Oklahoma, R.L. Williams. As a result, Smitherman aided in the arrest of 36 people including the Mayor of Dewey. ${ }^{124}$ In August of 1918, Smitherman received word of the stirrings of a race riot in Bristow, Oklahoma-about 35 miles southwest of Tulsa. A mob of "several hundred white men" had united in the task of lynching a young black man, Edgar Bohanan, who had been "arrested and charged with robbing and shooting a white man" that previous Friday. Stradford and Smitherman, who was acting as a Justice of the Peace in Tulsa at the time, assembled a small group of men and travelled to Bristow. Smitherman sent word by telegram to Governor Williams that read: "I am reliably informed that a race riot is imminent at Bristow. Kindly act at once." Twohundred "colored farmers" who were "armed to the teeth" defended Bohanan from the white lynch mob in Bristow, and he escaped on a northbound train to Sapulpa. Smitherman narrowly escaped becoming the focus of the mob as he left town, but managed to return to Tulsa unscathed. ${ }^{125}$ Later that same year, Smitherman and his brother freed an elderly African American woman from the home of a prominent white man, who was holding her in peonage, and returned her to her family in Louisiana. ${ }^{126}$ Thus, in Tulsa and in towns throughout the state, Smitherman and Stradford were successful in organizing black Oklahomans to upset the actions of certain whites. During meetings he held at the Tulsa Star offices, Smitherman reportedly proclaimed, "The day a member of our group was mobbed in Tulsa, the streets would be paved with blood."127

\footnotetext{
124 "Editor Smitherman Recipient of Many Letters of Commendation," Tulsa Star, August 30, 1918; Johnson, Black Wall Street, loc. 1054.

125 "Near Lynching at Bristow, Okla.: Cowards Failed to Lynch a Colored Man," Tulsa Star, August 24, 1918; Johnson, Black Wall Street, locs. 1054-1058.

126 Johnson, Black Wall Street, loc. 1063.

${ }^{127}$ Hirsch, Riot and Remembrance, loc. 1259.
} 
After the ending of World War I in 1918, both black and white veterans returned home. Having served their country overseas where they were often treated better than in the country they were fighting for, African American veterans held the belief that they earned the right to full citizenship and to be treated with respect and equality. These ideas proliferated within Tulsa's black community as did a willingness to engage in battle for their rights where they lived as they had done abroad. black veterans as well as private citizens in Greenwood were ready to fight should mob violence happen on their streets. ${ }^{128}$ In March of 1921, Smitherman and J.B. Stradford brought W.E.B. DuBois to Greenwood where the founder of the NAACP delivered a lecture. ${ }^{129}$ During those times, DuBois often lectured on white hate towards the black race and how "When the armed lynchers come, we too must gather armed. When the mob moves, we propose to meet it with sticks and clubs and guns." 130 The following month, in April of 1921, a group of African American men in Muskogee, prevented a lynching in their town by storming the jail, shooting a white deputy sheriff, and freeing the imprisoned black man, John McShane. ${ }^{131}$ Greenwood celebrated what they viewed as a successful thwarting of white vigilante justice. The next month in late May of 1921, the people of Greenwood had their own reckoning.

${ }^{128}$ Cameron McWhirter, Red Summer: The Summer of 1919 and the Awakening of Black America (New York: Henry Holt and Company, 2011), 12-13; Walker, The Rise and Fall of Black Wall Street, locs. 113-119.

${ }^{129}$ Walker, The Rise and Fall of Black Wall Street, loc. 340.

${ }^{130}$ Gerkin, "First Charged, Last Freed."

${ }^{131}$ Brophy, Reconstructing the Dreamland, locs. 391-398 


\section{Chapter Two}

“Conspicuous Disorder”: Greenwood, May 30, 1921-September 28, 1921

\section{Introduction: The Second Wave of Violence}

On May 30, 1921, a calamitous encounter in a downtown elevator between Dick Rowland and Sarah Page sparked the Tulsa Race Riot. The following day, Rowland was arrested for allegedly assaulting Page, a young white woman. His arrest was sensationally publicized by the local Tulsa press; the inflammatory headlines acted as an instrumental force in whites gathering in front of the courthouse where Rowland was being held, intent on his lynching. Armed black Tulsans, many of whom were veterans of World War I, confronted the white lynch mob, a shot was fired and the TRR was on. It continued through the late morning of June 1, 1921. By that evening, two nights of burning, looting, and killing left Greenwood in ruins and upwards of 300 people dead. ${ }^{132}$ In the weeks and months that followed, opportunistic city officials attempted a land grab for the "ashcovered acres" of Greenwood, seeking to displace the area's former residents outside of city limits. This was the second wave of violence.

\section{The Ballad of Jimmie Jones}

In July 1972, Ruth Sigler Avery interviewed eighty-seven-year-old Damie Rowland. As a child, Avery had witnessed the horrors of the TRR from her home in South Tulsa. Damie Rowland, who owned the Beech Hotel on Greenwood Avenue,

132 Ellsworth, Death in a Promised Land, locs. 1156-1161; Loren L. Gill, "The Tulsa Race Riot," (M.A. thesis, University of Tulsa, 1946), 45. 
experienced the violence of the Riot firsthand. Her son, Dick Rowland, was a central figure. Fifty years later, Damie Rowland recounted at her hotel in Greenwood her first memories of seeing six-year-old Jimmie Jones, Dick Rowland's original name, on the streets outside of her home in Vinita, Oklahoma. ${ }^{133}$

In Vinita, Damie ran a small one-room grocery store out of her living room and, one day, the "skinny, little, barefoot, black boy," who was wearing only a large man's shirt came in looking for food. "I'm hungry," he told her. Damie gave him milk and fixed him a sandwich. They went outside and sat in rocking chairs under the trees where he brought Damie water and played on the ground near where she sat. She was getting over a bout of the flu and remembers that Jimmie "had a winsome way of catering to me." They visited for about an hour and Damie learned Jimmie was an orphan who lived on the streets of Vinita with his two sisters. The siblings slept wherever they could and survived by begging for food and money. Jimmie offered to help Damie out around the house regularly if she would feed him. Damie liked the idea and had Jimmie go fetch his sisters. Once he and his sisters returned, Damie asked them if she could take Jimmie inhe could help her out and she would, in turn, care for him "just like a mother." Jimmie's sisters agreed since it meant for them that there was "one less mouth to feed," and from then on, said Damie, "I became Jimmie's mama." ${ }^{134}$ As with other black Oklahomans in

${ }^{133}$ Damie Rowland interviewed by Ruth Sigler Avery on July 22, 1972, transcript published in Bob Hower, ed., 1921 Tulsa Race Riot and the American Red Cross, "Angels of Mercy," (Tulsa, Oklahoma: Homestead Press, 1993), 228-230. This book was compiled from the memorabilia collection of Maurice Willows, Director of Red Cross Relief, by his grandson, Bob Hower.

${ }^{134}$ Hower, Angels of Mercy, 228. 
keeping with the culture of interdependence, Damie and Jimmie forged a mutually beneficial bond. They would be stronger together.

The following year, Damie and Jimmie moved to Tulsa, which was about sixtymiles southwest of Vineta. Her parents, Dave and Ollie Rowland, also decided to leave their home in Muskogee and move to Tulsa to be with Damie and Jimmie. They all lived together and rented out rooms in their home to bring in extra income, and, like he had done in Vinita, Jimmie helped out around the house. When Jimmie enrolled in school, he registered under his favorite name: Dick. He also took the name of his adoptive family, Rowland, for his own, becoming Dick Rowland. As he grew older, he took more odd jobs outside of the home, Damie recalls, "to help make us some extra money." By the time Dick Rowland entered high school, Damie worried that he might be running with "the wrong kind of crowd" in the red-light district on First Street, just north of the Frisco railroad depot. Damie also remembers that Dick "seemed to know a lot of white girls" who lived down on First Street, one of whom was named Sarah Page. ${ }^{135}$

In the spring of 1921, Rowland attended Booker T. Washington High School where a classmate remembered him as a star football player who "had a reputation of being a good looking ladies' man."136 Dick Rowland also shined shoes in downtown Tulsa on Main Street, one of the more lucrative jobs where a person could earn up to $\$ 10$ a day. Much of that income came from rich oil men, who were reputed to be exceptional tippers. ${ }^{137}$ The shoe shine parlor had no bathroom, so the owner arranged for his

\footnotetext{
135 Hower, Angels of Mercy, 228.

${ }^{136}$ Robert Fairchild interview by Eddie Faye Gates in Gates, They Came Searching, 71.

${ }^{137}$ Hirsch, Riot and Remembrance, loc. 686.
} 
employees to use the bathroom on the top floor of the nearby Drexel building, home to the popular department store Renberg's. The Drexel building was four stories tall, but its elevator made it a quick ride to the top and back down again. On Monday morning, May 30, 1921, 17-year-old Sarah Page, a possible acquaintance of Rowland's, was the elevator operator. Rowland boarded the elevator as he had done many times before. Minutes later, the doors opened and a Renberg's employee reported witnessing Rowland running out amidst a hail of Page's screams. ${ }^{138}$

What happened in the elevator remains unclear. Page alleged that Rowland had "seized her arm while she admitted him to the car," while Rowland claimed that he "stumbled and accidentally stept [sic] on the girl's foot."139 The following day, May 31, two Police Officers found Rowland on Greenwood Avenue and arrested him on charges of attempted assault. One of the arresting policemen was officer Henry Pack—one of Tulsa's two African American policemen out of a force that numbered forty-five in total. ${ }^{140}$ The officers took Rowland to the Tulsa County Courthouse to await his trial. Later that afternoon, provocative newspaper articles contributed to the decision made by many whites to gather outside of the courthouse in a mass call of white vigilante justice for the imprisoned Rowland. ${ }^{141}$

\footnotetext{
138 Ellsworth, Death in a Promised Land, loc. 780.

139 Walter F. White, Quoted in "Mob Fury and Race Hatred as a National Danger," Literary Digest, LXIX (June 18, 1921), 8.

${ }^{140}$ F. Jones, "96-Years Later, The Greenwood Cultural Center 1921 Race Riot Massacre Facts With Video," The Oklahoma Eagle, June 1, 2017, accessed on April 2, 2018, http://www.theoklahomaeagle.net/home/2017/06/01/96-years-later-the-greenwoodcultural-center-1921-race-riot-massacre-facts-with-video/. The Oklahoma Eagle is the successor to the Tulsa Star and has been in continual operation in Greenwood since 1921. ${ }^{141}$ Johnson, Black Wall Street, loc. 675.
} 


\section{Roots of Tradition: The Tulsa Outrage, 1917}

This was not the first time that local white newspapers in Tulsa were instrumental in the cultivation of public sentiment towards meting out vigilante justice. Four years before the TRR, the event that became known as the Tulsa Outrage provides important insight into how dire the outcome could be if the press, prominent white Tulsans, members of the Klan, and local government officials colluded against a group of people-even if they were white people. The Tulsa World along with the other two white newspapers in town, the Tulsa Tribune and the Tulsa Democrat were powerful forces in the creation of public sentiment and political sway. Most of the same actors present in the Outrage reappear in the TRR, but this time the targets of the mob's hatred were not white-they were black.

In 1917, the Tulsa World advocated for the lynching of members of the Industrial Workers of the World (IWW) because of their suspected involvement in the bombing of the home of vice-president of the Carter Oil Company, J. Edgar Pew. The IWW was rumored to be behind oil field strikes in Texas and Louisiana and were painted by the World as being enemies to the "unrestricted production of petroleum."142 Through this rumored association, members of the IWW in Tulsa were regarded as seditionist, antiAmerican, and were persecuted by the press, the local government, and law enforcement for belonging to the union.

Tulsa police officers raided the IWW hall on Brady Street where they arrested twelve men and placed them under bond. On November 8, their trial began with Judge

${ }^{142}$ Ellsworth, Death in a Promised Land, locs. 558-559. 
T.D. Evans presiding. ${ }^{143}$ The following morning, the World ran an article entitled "Get Out The Hemp" which read in part:

If the I.W.W. or its twin brother, the Oil Workers Union, gets busy in your neighborhood, kindly take occasion to decrease the supply of hemp. [...] Don't scotch 'em; kill 'em. And kill 'em dead. It is no time to waste money on trials and continuances like that. All is necessary is the evidence and a firing squad. ${ }^{144}$

The following afternoon Judge Evans had five other members of the IWW-who happened to be present in the courtroom that day-arrested, charged, and immediately tried. He found all seventeen men guilty and ordered them to be imprisoned in the County Courthouse, wherein the county jail was located. ${ }^{145}$

Around midnight, while nine Tulsa police officers began to transfer the prisoners to the county jail, they were confronted by fifty armed members of the Knights of Liberty, who instructed the police to drive the prisoners west of Tulsa into a secluded ravine. ${ }^{146}$ Once there, the Knights of Liberty whipped all seventeen of the prisoners with "a double piece of new rope, five-eighths or three-quarters hemp" before tarring and feathering them. They then ordered the prisoners to head out of town towards the Osage Hills. The mob dispersed and the police went back to town where later that evening signs cropped up at the Frisco station, the IWW hall, and other locations that read: NOTICE TO I.W.W.'S. DON'T LET THE SUN SET ON YOU IN TULSA. The notices were

\footnotetext{
143 Tulsa citizens voted Judge Evans into office as mayor in 1920, a position he held during the Tulsa Race Riot in 1921.

144 "Get Out The Hemp," Tulsa World, November 9, 1917.

145 Ellsworth, Death in a Promised Land, loc. 569.

${ }^{146}$ Ellsworth, Death in a Promised Land, loc. 574.
} 
signed by the "Vigilance Committee." 147 A headline printed by the Tulsa World that day exclaimed, "Modern Ku Klux Klan Comes into Being; Seventeen First Victims."148

While the involved members of the Police Force were adamant that they had done everything within their power to protect the prisoners, one year later, an investigation conducted by the National Civil Liberties Bureau (NCLB) brought to light evidence that reveals a different story. Based on testimony of the prisoners, the investigation found that five of the nine mob leaders were Tulsa policemen and the number of lashes each man received was determined by Tulsa Police Chief E.L. Lucas. ${ }^{149}$ All seventeen of the prisoners identified Tate Brady - a noted city booster and one of a number of prominent white citizens who signed the charter in 1898 that established Tulsa as a city—as being the man who applied the tar to their bodies. ${ }^{150}$ Brady was also a member of the Ku Klux Klan and was instrumental in helping the Klan establish a firm foothold within the State of Oklahoma and the City of Tulsa. ${ }^{151}$

${ }^{147}$ Ibid, locs. 593-596.

148 "Flogged, Tarred and Feathered: Modern Ku Klux Klan Comes into Being; Seventeen First Victims," Morning Tulsa Daily World, November 10, 1917, accessed on July 1, 2016, http://hislandpress.com/wp-content/uploads/2011/09/Screen-shot-2011-09-01-at7.58.17-AM.png.

149 "The Knights of Liberty Mob and the IWW Prisoners at Tulsa, Oklahoma (November 9, 1917)," National Civil Liberties Bureau, Brochure, (New York: New York, 1918), quoted in Nigel Anthony Sellers, Oil, Wheat, and Wobblies: The Industrial Workers of the World in Oklahoma, 1905-1930 (University of Oklahoma Press, 1998), 108-109. ${ }^{150}$ L.A. Brown of Civil and Criminal Investigations, Kansas City, Missouri, to Roger Baldwin of the National Civil Liberties Bureau, New York, New York, March 25, 1918, accessed on February 7, 2018, http://thislandpress.com/wpcontent/uploads/2013/07/labrown.jpg.

${ }^{151}$ Lee Roy Chapman, "The Nightmare of Dreamland," This Land Press, last modified April 18, 2012, http://thislandpress.com/2012/04/18/tate-brady-battle-greenwood/\#f6. In 1915, Nathan Bedford Forrest, who was then the acting General Secretary of the Sons of Confederate Veterans (and later became a founding member of the Ku Klux Klan and a Grand Dragon), wrote in the Confederate Veteran, that he visited Oklahoma where he 


\section{Back in Greenwood}

Just as the Tulsa World's battle cry of "Getting Out The Hemp" played a hand in the cultivation of public sentiment in 1917, so too did the headlines that came out on May 31, 1921. ${ }^{152}$ In the early afternoon of that day, the Tulsa Tribune published the headline: "Nab Negro for Attacking Girl in Elevator," and later, the paper purportedly published another edition with an article titled "To Lynch Negro Tonight." 153 Within forty-five minutes of the Tribune's first incendiary article, the police station received phone calls from citizens who reported that talk of lynching Rowland was fomenting on the streets. By 7:00 that evening, a growing mob of approximately 300 whites-including private citizens, influential Tulsans, and members of the Ku Klux Klan-gathered outside the courthouse. ${ }^{154}$

conferred with "Comrade Tate Brady," and the two were making plans for "an active campaign throughout Oklahoma." In 1918 - a year after the Tulsa Outrage - their plans came to fruition as the Tulsa Chamber of Commerce, led by Tate Brady, hosted the $28^{\text {th }}$ Annual Reunion of the Sons of Confederate Veterans in Tulsa. More than 40,000 people attended. The totem of the reunion gathering was General Nathan Bedford Forrest, who was the grandfather of Nathan Bedford Forest. Part of the mission of the Sons of Confederate Veterans was "the emulation of [the Confederate Veteran's] virtues, and the perpetuation of those principles he loved"-principles that were rooted in white supremacy. The Klan recruited many of their members from the Sons of Confederate Veterans.

152 Ellsworth, Death in a Promised Land, locs. 574-576.

153 "Nab Negro for Attacking Girl in an Elevator," and "To Lynch Negro Tonight," Tulsa Tribune, May 31, 1921. This headline has since disappeared and persists only in memory. The source, "To Lynch Negro Tonight," is problematic because the later edition of the archived May 31st, 1921 Tulsa Tribune is missing pages, one of which is the cover. I choose to include it because the existence of the article is mentioned in oral histories of survivors, one of which is a 1978 interview with W.D. Williams cited in Ellsworth, Death in a Promised Land. The article "To Lynch Negro Tonight" is also mentioned by riot survivor “A.H." in Mary E. Jones Parish's 1922 book, Events of the Tulsa Disaster (the earliest known study of the riots). In addition to these sources, this article is widely believed to exist among scholars of the Tulsa Race Riot.

${ }^{154}$ Ellsworth, Death in a Promised Land, loc. 845. 
In an oral history interview conducted by Eddie Faye Gates during the 1990s, Rosa Davis Skinner recalled that on the evening of May 31, 1921, she and her husband Thomas attended a Baptist Training Union (BTU) meeting at the Paradise Baptist Church in Greenwood. ${ }^{155}$ BTU meetings were intended to serve the needs of the church community by fostering 'better Baptists' through inspirational teaching on Baptist doctrine, church history, and ministry. ${ }^{156}$ During the meeting, Thomas stood and told the congregation about a vision that had recently come to him. "I don't know what it's going to be," he said, "but it's going to be some kind of destruction." 157 More likely than divine inspiration, Thomas's vision was quite probably influenced by reading headlines in the various newspapers that had come out earlier that day.

In Greenwood, people were going about the ordinary business of their daily lives that evening. The Mann brothers worked in their grocery store in Deep Greenwood. ${ }^{158}$ Eunice Jackson and her family sat out in the yard enjoying the cool late-spring Oklahoma evening. ${ }^{159}$ Opal Long Dargan, who would grow up to become a North Tulsa activist, was home sick with the measles, unhappy to be missing the end of the school year festivities at Booker T. Washington High School. ${ }^{160}$ Ernestine Gibbs attended the same

${ }^{155}$ Rosa Davis Skinner interviewed by Eddie Faye Gates in Gates, They Came Searching, 165.

${ }^{156}$ Merrill Jean Bailey, "Redefining the Baptist Training Union in African American Churches" The Journal of the Interdenominational Theological Center, Vol.40, No. 1 (Fall 2014), accessed on December 20, 2018, http://www.tabernacle-burlington.org/wp-content/uploads/2015/07/Tuesday-BaileyFinal.pdf.

${ }^{157}$ Skinner interview in Gates, They Came Searching, 167.

${ }^{158}$ Augusta Mann interviewed by Eddie Faye Gates in Gates, They Came Searching, 151.

${ }^{159}$ Eunice Cloman Jackson interviewed by Eddie Faye Gates in Gates, They Came Searching, 115-117.

${ }^{160}$ Opal Long Dargan quoted in Gates, They Came Searching, 193. 
school and was home that night studying for finals. ${ }^{161}$ Robert Fairchild was with his fellow classmates at the Dixie Theater on Greenwood Avenue where they were rehearsing for the impending high school graduation. ${ }^{162}$ The Skinners returned to their home after the BTU meeting that night where Rosa recalled that "Thomas didn't say no more about his vision." 163

Once news of the lynch mob reached the community in Greenwood, neighborhood residents congregated in different groups to discuss how best to handle the situation at the courthouse. Older, more prosperous residents, like O.W. Gurley, worried that they would suffer economic losses if things got out of hand. Hoping to diffuse the escalating violence, Gurley — who owned several properties and one of the best hotels in Greenwood-walked to the courthouse and spoke with Sheriff Willard M. McCullough, who assured him everything was under control. Gurley returned to Greenwood where he let others know that he believed there would be no lynching. ${ }^{164}$

Others in Greenwood were not so convinced that local law enforcement would be able — or willing — to hold out against the mob, and with good reason. ${ }^{165}$ Recent history demonstrated that the police force tended to acquiesce to lynch mobs, if not conspire with them. A little less than a year prior, a white mob lynched Roy Belton - a white man charged with committing murder. In that case, police handed their prisoner over to the lynch mob who then hung him from a large Federal Tire Company signboard on the

${ }^{161}$ Ernestine Gibbs interviewed by Eddie Faye Gates in Gates, They Came Searching, 85.

162 Fairchild interview in Gates, They Came Searching, 71.

163 Skinner interview in Gates, They Came Searching, 167.

${ }^{164}$ Hirsch, Riot and Remembrance, locs.1236-1240

165 Ibid.; F. Jones, "96-Years Later." 
outskirts of town. ${ }^{166}$ If law enforcement had not protected a white man from vigilante justice, how could black Tulsans expect that a young African American man would not be similarly handed over? ${ }^{167}$

Among those who doubted the willingness and capabilities of the police force to protect Rowland were J.B. Stradford and A.J. Smitherman. Around 9pm the two called a meeting in Greenwood at the Tulsa Star offices where they organized a group of approximately 30 armed black men, many of whom were veterans of WWI. ${ }^{168}$ Stradford declared, "If I can't get anyone to go with me, I will go single-handed and empty my automatic into the mob and, then, resign myself to my fate." ${ }^{169}$ However, it did not take much convincing and, armed with guns, the men set off for the courthouse. When they arrived, Barney Cleaver, the other black police officer on Tulsa's police force, assured them that everything was under control. Not satisfied with the situation, but seeing that they were greatly outnumbered, Stradford, Smitherman, and the others returned to Greenwood to regroup and organize. ${ }^{170}$ As the group of men started back north, many were part of a larger number of African American returning veterans who found they faced extreme violence on the home front.

166 Ellsworth, Death in a Promised Land, locs. 687-747.

167 Ibid, loc. 747.

${ }^{168}$ Hirsch, Riot and Remembrance, locs. 1253-1263.

${ }^{169}$ Ibid, locs. 1263-1268.

${ }^{170}$ Ibid. 


\section{Red Summer and Black Veterans of WWI}

Like many black veterans in Greenwood, African American veterans from WWI all over the country returned home after their stints fighting overseas emboldened to continue the fight for their own equality on American soil. In just $8 \frac{1}{2}$ months, between January 1 and September 14 of 1919, race riots erupted in 37 American cities. ${ }^{171}$ The crescendo of violence reached its peak during the summer of that same year, which historians refer to as the "Red Summer." In all, forty-three African Americans and four whites were lynched. White vigilantes targeted black veterans, and some were lynched in their military uniforms. White rioters sometimes burned their victims at the stake, while they hung or dismembered others - their bodies undergoing painful and humiliating acts of degradation before they died. Sometimes, local newspapers advertised lynchings beforehand. Some white citizens memorialized the process of killing with pictures, making them into postcards which they sold as mementos. Attempts at prosecuting members of lynch mobs were rare and no one was ever convicted for the Red Summer lynchings. ${ }^{172}$ After the summer of 1919, returning black veterans and other African American citizens realized with pronounced clarity that protection against racialized violence would not come from law enforcement or the government, but from within their own communities.

171 "For Action on Race Riot Peril: Radical Propaganda Among Negroes Growing, and Increase of Mob Violence Set Out in Senate Brief for Federal Inquiry," New York Times, October 5, 1919.

${ }^{172}$ McWhirter, Red Summer; Hirsch, Riot and Remembrance; Chad L. Williams, Torchbearers of Democracy: African American Soldiers in the World War I Era (University of North Carolina Press, 2010); "Lynching in America: Targeting Black Veterans," Equal Justice Initiative, accessed March 16, 2018, https://eji.org/reports/online/lynching-in-america-targeting-black-veterans. 
The racial violence of 1919 came at a time of growing American insecurity, as the nation strained under the pressure of hundreds of thousands of returning WWI veterans in search of jobs, the spread of Jim Crow, and the subsequent migration of large numbers of African Americans leaving the South in search of better living conditions in the North. ${ }^{173}$ The pages of the black press advocated for continuing to fight for racial equality. In the May 1919 edition of The Crisis—a black magazine established by the NAACP in 1910editor W.E.B. DuBois told returning African American veterans that they had fought during the war "For the America that represents and gloats in lynching, disfranchisement, caste, brutality and devilish insult," urging that "for this, in the hateful upturning and mixing of things, we were forced by vindictive fate to fight also," for, he concluded, "we are cowards and jackasses if now that that war is over, we do not marshal every ounce of our brain and brawn to fight a sterner, longer, more unbending battle against the forces of hell in our own land." 174 The racial violence they encountered on their own home front made it eminently clear to many black veterans, as it did with Stradford, Smitherman, and the other men in Greenwood, that they needed to actively defend their communities. Black soldiers returned home to Greenwood and other cities in America not to peacetime, but to wartime.

For many whites living in Oklahoma and other places throughout America, black soldiers during World War I were less a source of patriotic pride than they were a source of anxiety. Southern politicians feared that after undergoing military training and fighting for their country, returning black veterans would be empowered to fight for racial

173 Ibid.

174 W.E.B Du Bois, "Returning Soldiers,” The Crisis, XVIII (May, 1919), 13. 
equality back on the home front. During the war, in August of 1917, Mississippi Senator James K. Vardaman said that from this, it would be a forgone conclusion for the "untutored souls" of returning black soldiers "that his political rights must be

respected." ${ }^{175}$ Returning African American veterans were a threat to the entrenched social order of white supremacy, embodying the fear that many whites held that once back home, the veterans would have forgotten their place or would choose to fight against the established racial hierarchy. ${ }^{176}$ They were right. Returning black veterans rightfully felt they had earned the rights of full citizenship, and they were prepared to fight for those rights. Black success, empowerment, and heightened white fears in response to a shifting social order were central factors in the explosion of violence that was the TRR.

\section{The TRR: Violence in Four Acts}

\section{Act I: The Riot}

After the initial confrontation at the courthouse, groups of white men dispersed, equipping themselves with weapons from the Tulsa Armory, area hardware stores, and their own homes before returning to the growing lynch mob at the courthouse. By 10:00pm, the crowd of whites had reached upwards of 2,000 people. A group of about 75 African American veterans and citizens of Greenwood arrived, bearing arms but still greatly outnumbered. ${ }^{177}$

175 Williams, Torchbearers of Democracy, 31-32.

176 Williams, Torchbearers of Democracy, 226.

177 Ellsworth, Death in a Promised Land, locs. 885-890. 
Having full knowledge of the powder-keg outside of the courthouse, at about 10:00pm Tulsa's Chief of Police John A. Gustafson informed the Governor of Oklahoma, James Robertson, that the authorities in Tulsa had everything under control. ${ }^{178}$ Chief Gustafson was likely very aware that the situation outside the courthouse would escalate. By not asking Governor Robertson for help, Chief Gustafson positioned himself and other powerful white Tulsans, like Tate Brady, in the familiar stance of acting with impunity. ${ }^{179}$ Gustafson and Brady ran in the same local governmental circles. This is important to note because it is indicative of the probability of larger factors at work, such as the desire of Gustafson, Brady, and others to retain control in the city — and they were not above using violence to hang on to that power.

Different versions of the events surrounding the first gunshot that set sixteen hours of violence in motion are similar in the essentials, but vary in the particulars. No record exists of the names of the people directly involved although the majority of reports and eyewitness accounts concur that one man was wrestling a gun from another man when the weapon went off. According to one version heard by Robert Fairchild, at about 10:15pm on May 31, a member of the white mob outside of the courthouse where Rowland was being held confronted a tall black WWI veteran who was carrying an Army

\footnotetext{
${ }^{178}$ Hirsch, Riot and Remembrance, locs. 1393-1398. Gustafson was also the Chief of Police at the time of the Roy Belton lynching.

${ }^{179}$ In the months preceding the Riot, Chief Gustafson was under investigation for his involvement in vice rings within the city of Tulsa-involvement which he was later found guilty of and removed from office. Many of the vice activities Gustafson was under suspicion for, such as involvement in bootlegging, sex work, and stolen car rings, had their nexus of operations in and around Greenwood. One of the hotels implicated was the Brady Hotel, owned by Tate Brady who, by 1921, had risen even higher in the ranks of the Tulsa gentry.
} 
issue 45-caliber and said, "Nigger, what are you doing with that pistol?" To which the man responded, "I'm going to use it if I need to." "No," retorted the member of the lynch mob, "you give it to me." The black veteran responded, "Like hell I will." 180 The white man attempted to disarm the veteran, a scuffle ensued, and a shot was fired. Present at the courthouse that day was Sheriff Willard McCullough, who stated that from the moment of the first gunshot "the race war was on and I was powerless to stop it."

Accounts and memories of the violence of the Riot for both African Americans and whites coincide at points and diverge at others. In an oral history taken years after the TRR, W.R. Holway, a white Tulsan who was then the Water Commissioner for Tulsa County, recalled being in the Rialto movie theatre when a man burst in in the middle of the movie and shouted, "Nigger fight! Nigger fight!"182 "Everybody left that theatre on high" after that, spilling out into the street where they witnessed the shooting of an armed African American by an unidentified member of the mob. Holway claims that this was the first casualty of the TRR. An African American man named "A.H.", concurred with Holway's memory. A.H. recalled that "The first one was shot on Main Street right in front of the biggest picture house. [...] Three or four ambulances clanged down to the place, but the crowd turned on them and showed their guns. ${ }^{" 183}$ Holway, described the crowd gathering around the man and "wouldn't let anybody touch him or pick him up.

\footnotetext{
${ }^{180}$ Ellsworth, Death in a Promised Land, loc. 900.

${ }^{181}$ Ibid.

182 W.R. Holoway interview, Tulsa Historical Society Oral History Collection, accessed on April 3, 2018, https://soundcloud.com/user-604183945/wr-holway-interview. 183 A.H. quoted in Parrish, Events of the Tulsa Disaster (1922), University of Tulsa McFarlin Library, Department of Special Collections, 62, accessed February 15, 2015. http://cdm15887.contentdm.oclc.org/cdm/ref/collection/p15887coll1/id/129.
} 
Wouldn't let an ambulance pick him up." 184 The police did not show up for "quite a while," even though they were three short blocks away from the incident. Holway recalled how the violence escalated quickly with "cars of negros" driving up and down Main Street firing guns and whites fighting to "[drive] them back across the tracks" into Greenwood. It was "an armed conflict, the Frisco railroad tracks being the dividing line." 185 The railroad tracks were also, not inconsequentially, the dividing line between North and South Tulsa.

Twelve people died during the riot at the courthouse and, almost immediately, black Tulsans began a fighting retreat northward, fending off the mob at their heels and inadvertently drawing the violence into Greenwood. ${ }^{186}$ Even as African Americans sought to protect one of their own, they put their larger community and property at risk by providing white Tulsans with enough of a reason to engage in all-out battle and rain down terror upon Greenwood.

In Greenwood, people responded to the news of the riot approaching their community in different ways. Some decided to lie low while others prepared to fight. Augusta Mann, wife of one of the owners of the Mann Grocery store, remembers that when they heard that a riot was breaking out "they quickly closed up and went home."187 Augusta's husband stayed home with the family while his brother, Obie - a veteran of WWI-joined the other men out on the streets. ${ }^{188}$ As they sat in the yard in front of their

\footnotetext{
184 Holoway, interview.

185 Ibid.

${ }^{186}$ Walter F. White, "The Eruption of Tulsa," The Nation, June 29, 1921.

${ }^{187}$ Mann interview in Gates, They Came Searching, 151.

188 Jackson interview in Gates, They Came Searching, 117.
} 
home, Eunice Jackson recalled that "people were running toward us and hollering $[\ldots]$

'There's a riot over on Brickyard Hill (Greenwood Avenue area). They're just shooting everybody they can!" "189 She recalled waves of more and more black people running past their house and she and her family joined the crowd of "men, women, and children - all just running, running for our lives!”190

When Opal Long Dargan's mother heard about the Riot breaking out, she thought they could wait it out, but soon realized that would not be possible. ${ }^{191}$ Opal's classmate, Ernestine Gibbs, recalled that that night "A man knocked on our porch and said, 'Put out the lights. There is fighting and burning on Greenwood." ${ }^{192}$ Another member of their class, Robert Fairchild, remembered that "someone came in and told the instructor to let us go because there was going to be trouble on Greenwood." ${ }^{193}$ The instructor let them go around 8:30pm and Fairchild recalls that as they left the theater Greenwood was "packed with people." Fairchild made his way home, but "things kept getting worse. All you could see and smell was smoke and fire; and you could hear those gunshots going off. I was so scared." 194 That night Thomas Skinner woke his wife, Rosa, saying, "I told you something was goin' to happen; well it's happenin' now. A man just run by the house and he said 'Brothers, get your guns, get your guns, a riot has broke out."'195

\footnotetext{
189 Ibid.

${ }^{190}$ Ibid

${ }^{191}$ Dargan interview in Gates, They Came Searching, 193.

192 Gibbs interview in Gates, They Came Searching, 85.

${ }^{193}$ Fairchild interview in Gates, They Came Searching, 71.

194 Ibid.

195 Skinner interview in Gates, They Came Searching, 167.
} 
In South Tulsa, whites were also figuring out how to respond to the outbreak of violence. South Tulsa resident, Fannie Misch, later recalled during her oral history interview that, "Just at suppertime on a pleasant evening, the race riot was started. I won't tell much of it. I lived through it pretty close." 196 When pressed by her interviewer who said, "Well, it ought to be recorded," Misch reluctantly went into a bit more detail. She told of how "a disastrous race war" was started when "two carloads of negro men $[\ldots]$ all armed with shotguns," came into South Tulsa to "release a prisoner on the top floor of the courthouse." Misch claimed that at the time of their arrival, many of the stores were closing for the day and that it was generally "very quiet over town." Misch recalled how "of course the citizens - white citizens — quickly armed," elaborating that many of these "citizens" began breaking into the stores in order to secure weapons. ${ }^{197}$ To Misch, this seemed a natural reaction — a forgone conclusion — that in response to carloads of armed African Americans, white citizens would immediately seek to arm themselves and prepare for a fight — even though the blacks were not looking for a fight initially, but to protect Dick Rowland from an almost certain fate of lynching. "The real battle," recalled Misch, did not start in front of the courthouse or even on the streets of South Tulsa where the riot began. It started at the Frisco railroad station where whites, some of whom were members of the Klan, were engaged in battle with African Americans, many of whom were veterans. ${ }^{198}$

\footnotetext{
${ }^{196}$ Fannie Misch interview, Tulsa Historical Society, accessed on April 3, 2018, https://soundcloud.com/user-604183945/fannie-misch-interview.

${ }^{197}$ Ibid.

${ }^{198}$ Ibid.
} 
After the initial riot at the courthouse W.R. Holway made his way back home to check on his family. He remembered his next door neighbor calling him later that night urging, "Get your guns! Get your guns! The niggers are coming!" Holway recalled that people "were doing that all over town."199 The person interviewing Holway asked "Did they?," meaning did African Americans invade South Tulsa. Holway responded, "No. No, it was the other way around. The whites went over there. [...] Mostly it was Klansman who took that opportunity to do something definite.” The Klan, asserted Holway, "ran the whole country and state," in the years that followed WWI. ${ }^{200}$ Tony Pringer recalled in a 1996 oral history interview that his grandfather, Herbert Johnson was a firefighter in Tulsa. He was also a Klansmen. Tony Pringer explained, "It was just a common thing, a common practice, for white men in business and in government in Oklahoma during the early 1900 s to belong to the Klan."201

Indeed, many white Oklahomans had strong allegiances with the culture and ideals that the Klan embodied, including the preservation of Protestant Christianity and upholding the racial order of white supremacy. The Klan sought out members who were not only sympathetic to their system of beliefs, but also were men of a certain position of power. They recruited members from local law enforcement, civic leaders, prominent businessmen, and government officials, as well as the Protestant Church. ${ }^{202}$ Klan activity in Oklahoma peaked in the early 1920s, with membership in Oklahoma City at twenty-

\footnotetext{
199 Holoway, interview.

200 Ibid.

201 Tony Pringer interviewed by Eddie Faye Gates in Gates, They Came Searching, 253. ${ }^{202}$ Linda Gordon, The Second Coming of the KKK: The Ku Klux Klan of the 1920s and the American Political Tradition (Liveright Publishing, 2017, Kindle edition), chapter 4.
} 
five-hundred and Tulsa Klan membership at two-thousand in $1921 .{ }^{203}$ However, not every white Tulsan was a member of the Klan. Neither did all agree with their tactics. In later years, many shared the belief that the TRR was orchestrated by the Klan who used the elevator incident, as white Tulsan John Bullock put it during his 1995 oral history interview, "as an excuse to do what they wanted all along." Bullock recalled that the TRR "had been brewing for a long time. There was so much [race] hatred in Tulsa at that time." 204

\section{Act II: The Battle}

As the mob fought black Tulsans into the north, the fighting moved away from the courthouse and into Greenwood. With movement into North Tulsa, the Tulsa Police force made the tactical decision to trap people in Greenwood. To accomplish this, they increased their manpower by deputizing whites, many of whom were members of the initial lynch mob. They now operated under the auspices of the law as legally appointed "special deputies." 205 At 11pm, the Home Guard Company, a special militia headed by Tulsa Police Commissioner J.M. Adkinson and Police Inspector C.W. Daley, organized 300 white Tulsans into six companies of 50 men each. Adkinson and Daley then armed, drilled, and coached the men before marching them into "advantageous positions" where

${ }^{203}$ Gordon, The Second Coming of the KKK, locs. 1589-1594; Larry O'Dell, "Ku Klux Klan," The Encyclopedia of Oklahoma History and Culture, accessed April 8, 2018, http://www.okhistory.org/publications/enc/entry.php?entry=ku001. ${ }^{204}$ John Bullock interviewed by Eddie Faye Gates in Gates, They Came Searching, 244. ${ }^{205}$ Ellsworth, Death in a Promised Land, loc. 924. 
they could prevent area residents from escaping Greenwood. ${ }^{206}$ Around the same time, Captain John W. McCuen of the "B" Company, $3^{\text {rd }}$ Infantry, Oklahoma National Guard reported for duty along with his men at the Tulsa Armory. Tate Brady volunteered for guard duty that night. ${ }^{207}$

Shortly after midnight on June 1, the battle approached Greenwood where white rioters began setting fire to some of the buildings. Armed blacks organized and held the line at the Frisco railroad station, Santa Fe Depot, where they engaged in gunfire with whites who were gathered to the south of the depot. After about an hour-and-a-half of shooting, the whites rushed the line, breaking through. African American fighters retreated a block north to the railroad tracks where they continued to hold the line. ${ }^{208}$

McCuen and the "B" Company moved in, setting up a skirmish line a block to the west on Detroit Avenue, where they awaited the reinforcements Police Chief Gustafson had requested from Governor Robertson by telegram around 12:30am. While they waited, McCuen and his men moved back and forth between Cameron and Archer streets in Greenwood where they rounded up prisoners and turned them over to the police. ${ }^{209}$

Whites feared a black "counterattack," coming at them from Tulsa's outlying areas and rumors of impending black violence abounded. The first of these rumors were of a train full of militant black Muskogeans headed for Tulsa. Police Inspector Daley gave Lieutenant Colonel L.T.C. Rooney of the National Guard a truck-mounted machine

${ }^{206}$ I. Marc Carlson, "Timeline of the Tulsa Race Riot," The Tulsa Race Riot of 1921, last modified July 18, 2012, http://www.personal.utulsa.edu/ marccarlson/riot/tulsatime.html.

${ }^{207}$ Chapman, "The Nightmare of Dreamland."

${ }^{208}$ Carlson, "Timeline of the Tulsa Race Riot."

${ }^{209}$ Ibid. 
gun from the Armory to meet the train. A number of African American populations in Eastern Oklahoma were rumored to be organizing retaliatory efforts as well and the Tulsa police sent an airplane to surveil the area. The pilot, Captain Blaine, saw no evidence of any such uprising. ${ }^{210}$ Over a hundred "car squads" were deployed to guard the roads leading into town. ${ }^{211}$ Fannie Misch recalled that because of these reports, "Trains didn't go through [Tulsa] for three days." ${ }^{212}$ The rumors proved to be false, but are indicative of the anxieties of white Tulsans.

Back in Tulsa, Captain McCuen deployed about 60 troops to form a skirmish line on Standpipe Hill, overlooking the western edge of Greenwood which was alight with burning buildings. McCuen and his troops were fired upon from the east and he sent some of his men down into the northern section of Greenwood where they encountered a group of barricaded black fighters, two of which they killed for refusing to surrender. ${ }^{213}$ African Americans continued to engage in active and strategic battle by decentralizing and firing into white neighborhoods that surrounded Greenwood. They held the line along the railroad tracks as whites increased the intensity of their fighting, trying to push their way into Greenwood. More armed blacks joined the railroad defensive line to protect their district from invasion by the white rioters. Lieutenant Rooney, who was under Captain McCuen, recounted in a later testimony that these men "fought like tigers." ${ }^{214}$ Fighting continued in this manner until approximately 2am, when African

${ }^{210}$ Ellsworth, Death in a Promised Land, locs. 1298-1307.

${ }^{211}$ Carlson, "Timeline of the Tulsa Race Riot."

${ }^{212}$ Misch, interview.

${ }^{213}$ Carlson, "Timeline of the Tulsa Race Riot."

${ }^{214}$ Hirsch, Riot and Remembrance, locs. 1444-1449. 
Americans at the railroad defensive line succeeded in pushing back the white vigilantes and things fell relatively quiet in Greenwood. ${ }^{215}$

The citizens of Greenwood won the battle, but, as the saying goes, they did not win the war. That blacks were successful in this second act of the TRR is not something that is often focused on in secondary sources about the Riot. However, A.J. Smitherman memorialized their success in battle in a poem he wrote in early 1922 entitled, "A Descriptive Poem of The Tulsa Race Riot and Massacre":

Nine p.m. the trouble started,

Two a.m. the thing was done.

And the victory for the black men

Counted almost four to one.

In the next stanza, Smitherman describes how whites, defeated by the black defensive line, organized and began planning the wholesale burning, looting, and killing of Greenwood in earnest. ${ }^{216}$

Then the whites went into council, Hoping to reprise their loss, Planned the massacre that followed, Dared to win at any cost. ${ }^{217}$

What followed can indeed best be described as a massacre.

${ }^{215}$ Carlson, "Timeline of the Tulsa Race Riot." ${ }^{216}$ Carlson, "Timeline of the Tulsa Race Riot."

217 A.J. Smitherman, "A Descriptive Poem of the Tulsa Race Riot," 1922, accessed on April 8, 2018, http://www.personal.utulsa.edu/ marc-carlson/riot/smithermanpoem.html. 


\section{Act III: The Massacre}

In the pre-dawn twilight, a loosely assembled army of white rioters broke into Greenwood in two movements, first through the black defensive line where they were covered by snipers, and second down Standpipe Hill where they had established a skirmish line and were covered by a machine gun on the hilltop. At this point, the trajectory of the organized violence moved from the poorer neighborhoods at the edges of Greenwood, into "Deep Greenwood" — the heart of black Tulsa—where gunfire raged throughout. $^{218}$

Planes piloted by white civilians circled overhead, locating and targeting African American snipers and groups of barricaded black fighters. They also fired down on black citizens, many of whom were unarmed, had surrendered, or were fleeing the battlefield. Several witnesses reported that this second stage of the battle started after a loud whistle blew. ${ }^{219}$ An excerpt from Smitherman's descriptive poem reads:

June the First, at five a.m. Three long whistle blasts were heard, Giving sign for concert action To that cold blood-thirsty herd.

At the signal from the whistle Aeroplanes were seen to fly, Dropping bombs and high explosives, Hell was falling from the sky.

On all sides the mob had gathered

Talking in excited tones

218 Ellsworth, Death in a Promised Land, loc. 981.

219 Carlson, "Timeline of the Tulsa Race Riot." 
With machine guns, ready, mounted, Trained upon a thousand homes. ${ }^{220}$

White rioters claimed that they were fired upon by snipers holed up in the belfry tower of the "new brick Negro church." 221 In front of Mount Zion Baptist Church blacks and whites engaged in an all-out battle as blacks fought to defend the newly constructed church. Riot survivor Binkley Wright recalled that Len and Clark Holderness, both in their twenties, joined the "protective brigade" in fighting off the white mobs that were entering Greenwood. "The Holderness boys," recounted Wright, "went high up into the church, into an attic room [where] they killed many white mobsters."222 Wright goes on to tell that, while the Holderness boys survived, many of the black men "who were defending Greenwood [at] Mt. Zion Church were killed when heavily armed white mobs broke through, and when airplanes flew over, dropping bombs or something that exploded and burned everything they touched." ${ }^{223}$ By 7:30 am, nearly all of Greenwood was burning and upwards of two-thousand African American citizens were fleeing the area into the north. At the base of Sunset hill, which was slightly to the north and east of Standpipe hill, Captain McCuen's men and black fighters engaged in nearly twentyminutes of "fire at will” before the black fighters retreated and McCuen's company moved forward. ${ }^{224}$

${ }^{220}$ Smitherman, "A Descriptive Poem of the Tulsa Race Riot."

${ }^{221}$ Carlson, "Timeline of the Tulsa Race Riot."

${ }^{222}$ Gates, Riot on Greenwood, 110.

${ }^{223}$ Ibid.

${ }^{224}$ Carlson, "Timeline of the Tulsa Race Riot." 
At 8:30am, Sheriff McCullough managed to sneak Dick Rowland out of town. The National Guard arrived in Tulsa at 9:15am, with their first order of business being to disarm the white vigilantes. Instead of immediately taking to the streets, the guardsmen settled in, ate breakfast, and prepared for what lay ahead. Witnessing the chaotic state of Tulsa upon the arrival of his troops, Adjutant General Chas F. Barrett called Governor Robertson and requested that he declare martial law. ${ }^{225}$

At this point, the fires in Greenwood were uncontrollable. Having stood for only a short time, white vigilantes looted and burned Mount Zion to its concrete foundation. It is estimated that 8 African Americans were killed during the battle at the church. ${ }^{226}$ The 57 day-old church, like much of its surrounding area, succumbed to the white rioters - the landscape of Greenwood reduced to scorched earth and piles of rubble. All told, 35blocks on which were situated 1,256 homes along with virtually every other building in Greenwood were deliberately destroyed between the hours of 6:00 and 11:00 on the morning of June 1.227 Upwards of three-hundred people died. Alice Andrews remembered of the massacre, "It looked like the world was on fire." 228

\section{Interlude: Martial Law and Internment}

At 11:00am on June 1, Governor Robertson put martial law into effect. After this, violence for the most part ceased. The National Guardsmen concentrated on assisting the fire department in subduing the flames of the burning city, rounding-up and imprisoning

225 Ellsworth, Death in a Promised Land, locs. 1035-1040.

${ }^{226}$ Hirsch, Riot and Remembrance, loc. 1611.

227 Don Ross, et al., Tulsa Race Riot.

228 Alice Andrews interviewed by Eddie Fay Gates in Gates, They Came Searching, 43. 
any black citizen who had not already been interned, while removing any others from the hands of the "special deputies" and other whites who were their initial captors. ${ }^{229}$ The guardsmen disarmed whites and sent them home, while African Americans were taken to internment camps at the convention hall, the baseball field, or the fairgrounds, whether they were armed or not. On the night of June 1 over 6,000 blacks were taken into custody and interned by National Guardsmen. ${ }^{230}$

After the TRR, blacks became both prisoners and refugees. Eunice Jackson recalled that as they were fleeing north, the mass of people were stopped at "The Section Line," which was the intersection of Greenwood and Pine. "It was a big crowd of us black people by then," remembered Jackson. Armed whites marched them to the Convention Hall on Brady Street where she recalled that they "stayed all afternoon."231 Opal Long Dargan remembered that "The second day, June, 1, 1921, things got so bad that it became obvious that black people could no longer remain in their homes and businesses on Greenwood Avenue or in the Greenwood area."232 Opal and her mother joined the other people walking down the Frisco Railroad tracks trying to get out of town. "I remember that we all walked parallel to the Frisco Railroad tracks heading south and east. What a sight we were - black mothers with babies in arms, and children of all ages by their sides, all of them walking down dusty paths trying to get to safety." ${ }^{233}$ When day

${ }^{229}$ Ellsworth, Death in a Promised Land, loc. 1043; Carlson, "Timeline of the Tulsa Race Riot." The Oxford English Dictionary defines internment as "the state of being confined as a prisoner, especially for political or military reasons."

${ }^{230}$ Ellsworth, Death in a Promised Land, loc. 1076.

231 Jackson interview in Gates, They Came Searching, 117.

${ }^{232}$ Dargan quoted in Gates, They Came Searching, 193.

233 Ibid. 
broke Ernestine Gibbs and her family joined the others who were trying to get out of Tulsa, "moving down the train tracks like ants." They came to a house owned by a white man who invited them into his home. Soon after, Ernestine remembered that "Men came by in cars and took us to the fairgrounds. There we were given food, water, and pop."234 Among the interned was Dick Rowland's acquaintance Robert Fairchild, who left his home that morning and fled north up the Midland Valley Railroad tracks. He was stopped by the National Guard who took him to the fairgrounds where he was given pork and beans to eat for supper. That night he slept in an animal display barn. "They gave me a blanket so, I went on in and piled up on some hay. Went to sleep. I woke up the next morning and asked the [National Guardsman] if I could go to work." ${ }^{235}$ The National Guardsman allowed Fairchild to go to South Tulsa where he worked at the "Indian Store." After work, he returned to Greenwood. Walking through the burnt rubble of his neighborhood, Fairchild found the house where he lived with his mother and siblings still standing. "Of course all that area back south of us was burned. The church. The school. Hospital. Everything."${ }^{236}$

The following day, on June 2, Adjutant General Charles Barrett issued Field Order Numbers 4 and 5. Field Order Number 4 directed that "all able bodied negro men remaining in the detention camp at the fairgrounds and other places in the city of Tulsa" will be "required to render such service and perform such labor as is required by the

234 Gibbs interview in Gates, They Came Searching, 86.

235 Robert L. Fairchild, interview by Scott Ellsworth, June 8, 1978, Duke University Oral History Program, box 2, Rubenstein Library and University Archives, Durham, North Carolina.

236 Ibid. 
military commission and the Red Cross in making the proper sanitary provisions for the care of refugees." ${ }^{237}$ Field Order Number 5 closed the internment centers and ordered the removal of all prisoners - more than 4,000 people - to the fairgrounds. ${ }^{238}$ Both during and immediately following the Riot the movements of African Americans were highly policed and restricted. They were not allowed on the streets unless they possessed an identification tag or, if employed on the south side of town, a green job tag countersigned by their employer and with the words "Police Protection" printed on one side. black employees working on the white side of town had to stay indoors once they reached their place of employment until it was time for them to return home again. ${ }^{239}$

\section{Interlude: Bodies}

The atrocities of the TRR were not limited to property loss and wrongful imprisonment; they included a staggering loss of lives as well. Newspaper estimates in the days that followed the Riot ranged from an early estimate of 175 in the Tulsa Tribune on June 1, 1921, to a report the next day that only 36 people had died. Eyewitness accounts of survivors are peppered with accounts of truckloads of bodies, "stacked like cord wood," being driven through the streets of downtown Tulsa. ${ }^{240}$ Estimates in Red

\footnotetext{
${ }^{237}$ Ellsworth, Death in a Promised Land, 1244-1265.

${ }^{238}$ Ibid.

${ }^{239}$ Ed Wheeler, "It Happened in Tulsa" Impact Magazine, June-July edition, 1971; Margarett Zulpo, "Remembering when the Sky Rained Death: 95-Year-Old-Women Recalls Race Riot," Tulsa World, May 18, 1994.

${ }^{240}$ Gates, Riot on Greenwood, 161; Bullock interview in Gates, They Came Searching, 244; Viola Clowes interviewed by Eddie Faye Gates in Gates, They Came Searching, 245; H.A. Johnson interviewed by Eddie Faye Gates in Gates, They Came Searching, 247.
} 
Cross records are as high as 300 with Maurice Willows, Director of the American Red Cross, writing in his 1921 end of the year report, "The number of dead was and still is a matter of conjecture. [...] Many bodies were hurriedly rushed to burial without records being made." 241

TRR survivor testimony further complicates the number of the dead. H.A. Johnson, a white Tulsan who was 15-years old at the time of the Riot, recalled that he "saw bodies lying in the streets, stacked up beside buildings, and piled upon flatbed trucks." ${ }^{242}$ Early TRR historian, Ruth Sigler Avery attributed her interest in the Riot to witnessing the bodies of black victims being deposited in the Oaklawn Cemetery at $11^{\text {th }}$ and Peoria, which was close to her childhood home. ${ }^{243}$ Another white Tulsan, Maxine Carnahan, remembered hearing that "bodies of some of the colored dead" were dumped into the muddy waters of the nearby Arkansas river. ${ }^{244}$ New to Tulsa and house hunting on the West Side of town, Viola Clowes's father's truck was commandeered by the Tulsa police who "forced him to pick up and dispose of the bodies of dead colored people. He didn't want to do it, but he had no choice. He was appalled by what he saw." Viola stated that this police ordered act affected her father's mental condition for the rest of his life. ${ }^{245}$ Russell King, who lived in Sand Springs, Oklahoma at the time, drove to Tulsa to see the smoldering ruins of Greenwood. He most vividly remembered, "the smell of burning

241 Gill, "The Tulsa Race Riot," 45; Gates, They Came Searching, 267.

242 Johnson interview in Gates, They Came Searching, 247.

243 "Ruth Avery-Parker, Race Riot Historian, Dies," Tulsa World, November 6, 2001.

${ }^{244}$ Maxine Carnahan interviewed by Eddie Faye Gates in Gates, They Came Searching, 244.

${ }^{245}$ Clowes interview in Gates, They Came Searching, 245. 
flesh. I can shut my eyes and still smell that flesh."246 Mary Jo Taylor, shares King's memory stating, "The smell of burning flesh is what left such a deep impression on my mind. [...] There was so much race hatred then." ${ }^{247}$ Phillip Rhees shares this memory stating that in Tulsa, "There was just an attitude at that time that any time was 'open season' on black people. [...] There was just an attitude that black people didn't count for much." ${ }^{248}$ The violence of the Riot did little to improve that attitude. If anything, it enabled it to become more firmly entrenched, enduring for decades after the physical violence was finished and manifesting in subtler, more diffuse waves of violence over the course of the years and decades that followed.

As for black bodies, Mr. Jackson of Greenwood's Jackson's Funeral Parlor attended to those. Among the dead Mr. Jackson embalmed was the body of Dr. Jackson, a member of his own family. Mr. Jackson's wife, Eunice Cloman Jackson, recalled that even before the TRR "When a black person died, [...] white funeral home owners wouldn't pick up the body. [...] They just wouldn't touch a black body." ${ }^{249}$ As the white mob destroyed Jackson's funeral home during the Riot and white funeral directors would not touch a black body, the white-owned Stanley-McCune Funeral Home hired Mr. Jackson to tend to the black dead. They paid him $\$ 25.00$ per body and he worked for five-days straight embalming the dead and staying in the Stanley-McCune servant's quarters. ${ }^{250}$ Mr. Jackson relayed to his wife the conditions of some of the black bodies he

\footnotetext{
${ }^{246}$ Russell King interviewed by Eddie Faye Gates in Gates, They Came Searching, 249. ${ }^{247}$ Mary Jo Taylor interviewed by Eddie Faye Gates in Gates, They Came Searching, 261.

248 Phillip Rhees interviewed by Eddie Faye Gates in Gates, They Came Searching, 259. 249 Jackson interview in Gates, They Came Searching, 115.

${ }^{250}$ Gates, They Came Searching, 267.
} 
embalmed, telling her of the bullet holes, stab wounds, and blunt-force trauma that betrayed their method of death. Dr. A.C. Jackson's body — who the Mayo brothers referred to as "the most able negro surgeon in America,"-was "just full of gunshot wounds." 251

Interlude: Things we lost in the fire

After their release from internment at Tulsa's Convention Hall, Eunice Jackson and her family returned to Greenwood. Her mother carried a purse that held a gun belonging to her son, Eunice's brother. As they traversed the scorched and unrecognizable landscape, not knowing if there was a home to return to, they were stopped by a policeman who questioned them saying, "What you got in the bag, Auntie?" The policeman confiscated the gun and let them pass. When they arrived at the corner of Marshall and Elgin Streets they were relieved to find that their house was still standing. ${ }^{252}$ They were unlike many other Greenwood residents who, like Otis Clark, lost their homes in the fire. Clark recalled of his homecoming after the Riot, "There was nothing there but ashes." ${ }^{253}$ Among those left homeless were Greenwood's founding fathers: A.J. Smitherman, J.B. Stradford, and O.W. Gurley.

Like lives and property, the loss of leadership within the community of Greenwood was another casualty of the TRR. For Smitherman, having his home as well as the Tulsa Star building destroyed by white rioters was enough cause for him to leave

251 Ibid.

252 Jackson interview in Gates, They Came Searching, 117.

${ }^{253}$ Otis Clark interviewed by Eddie Faye Gates in Gates, Riot on Greenwood, 64. 
Tulsa. He relocated with his family to Springfield, Massachusetts where he eventually started another newspaper. J.B. Stradford also left after everything he had built and worked for was lost in the fire, relocating to Chicago. With his fears of losing his wealth and property realized, O.W. Gurley left Tulsa and headed west to California. ${ }^{254}$ Buck Colbert Franklin recalled that in post-Riot Tulsa, "there was a great letdown in faith, ambition, hope, and trust. The immediate future was blank.[...] Many followed [Stradford and Gurley's] example, in the belief, no doubt, that if men like them were afraid to remain and face the future, then the weaker could not hope to survive. $" 255$ The loss of civic leaders in Tulsa's African American community is often cited as one of the most harmful outcomes of the violence of the Riot, but some like Buck Colbert Franklin did not leave. Those who stayed helped rebuild.

B.C. Franklin was released from the detention camp on June 2 and returned to his law office to find "a smoldering ruin." 256 The rooming house where he lived was in ashes. Among the ashes was money he had saved to move his wife and children from Rentiesville to Tulsa. In light of the TRR, Franklin expressed that he held "nothing but mistrust and misgivings for the future," and, after discussing it with his wife, they came to an agreement that "it was better for her to hold on till we could see our way more

${ }^{254}$ Larry O'Dell, "Smitherman, Andrew J.," The Encyclopedia of Oklahoma History and Culture, accessed February 23, 2018, http://www.okhistory.org/publications/enc/entry.php?entry=SM008; Alimcar Shabazz, "Smitherman, A.J. (1883-1961)," Blackpast.org, accessed May 14, 2018, http://www.blackpast.org/aaw/smitherman-andrew-j-1883-1961; Hirsch, Riot and Remembrance, loc. 2360.

${ }^{255}$ Franklin, My Life and an Era, 201.

256 Ibid, 197. 
clearly."257

Interlude: The Trial

Dick Rowland was indicted on June 6, 1921 with "unlawfully, willfully, wrongfully, forcibly, violently, and feloniously" assaulting and attempting to "ravish, rape, and carnally know" Sarah Page, a woman of "previous chaste and virtuous character." 258 Sarah Page refused to press assault charges and, in September of 1921, all charges against Rowland were dismissed. ${ }^{259}$ Both left Tulsa and, according to Damie Rowland, moved to Kansas City, Kansas where they lived together for a while. Damie lost her home in the fires of the TRR and, although she occasionally received letters from her son, she never saw him again. Dick Rowland eventually moved to Oregon to work in the shipyards during World War II. ${ }^{260}$

Police Chief Gustafson was found guilty of failing to take proper precautions for the protection of life and property during the Riots. Although the grand jury indicted him for negligence and for his participation in a stolen car ring, Gustafson never served jail time; however, he was removed from office. ${ }^{261}$ On June 6, J.B. Stradford was the first person formally charged with inciting a riot, but by the time he was charged he had escaped to Chicago. The Tulsa authorities never managed to extradite him. ${ }^{262}$ In the end,

257 Ibid, 201.

${ }^{258}$ State of Oklahoma vs. Dick Rowland, Case No. 2239, Tulsa County District Court, filed June 18, 1921.

259 Ibid.

${ }^{260}$ Hower, Angels of Mercy, 230.

${ }^{261}$ Ellsworth, Death in a Promised Land, loc. 1630; Hirsch, Riot and Remembrance, locs. 1905-1914.

${ }^{262}$ Chapman, "The Nightmare of Dreamland." 
Garfield Thompson, a black man who was arrested during the Riot for carrying a concealed weapon was sentenced to thirty days in the county jail. No one else served any jail time for crimes perpetrated during the TRR as Tulsa city officials dropped all charges against the rioters. It was their hope that this act of admonition would help alleviate the "humiliation of the citizenry."263 A grand jury later placed the blame for the Riot squarely on the shoulders of black Tulsans, clearing the city of any and all responsibility. This ruling made it so that no one who had suffered damages during the Riot would be able to collect on their insurance claims, which meant that residents would have to rebuild Greenwood on their own dime.

The process of rebuilding presented its own set of disheartening obstacles beginning with the attempted passage by influential white Tulsans of a new zoning ordinance. "While the ashes were still hot from the holocaust," recalled B.C. Franklin, "certain questionable real estate men influenced the mayor and city commissioners to enact an ordinance with an emergency clause prohibiting owners of lots in the burned area from rebuilding unless they erected fireproof buildings." ${ }^{264}$ After burning Greenwood down and displacing its residents, Tulsa city officials and prominent white citizens made their first efforts at permanently displacing neighborhood residents with a land grab which B.C. Franklin and his law office worked successfully to strike down.

\footnotetext{
${ }^{263}$ Grand Jury Report, Final Report of the Tulsa Grand Jury, Oklahoma State University Tulsa Special Collections and Archives, Ruth Sigler Avery Tulsa Race Riot Archive, Series 2, Research Box 6. ${ }^{264}$ Franklin, My Life and an Era, 198-201.
} 


\section{Act IV: The Land Grab}

On June 7, just six days after the Riot, Tulsa's Mayor T.D. Evans formed a Reconstruction Committee to which he appointed Tate Brady and other influential white Tulsans. They worked to pass a fire zoning ordinance that would make it impossible to rebuild residences in Greenwood and proposed converting the valuable land into an industrial warehouse district. Blacks, the committee reasoned, could rebuild further into the north. The stated intent was to further segregate Tulsa. "We believe," explained members of the committee, "that the two races being divided by an industrial section will draw more distinctive lines between them and thereby eliminate the intermingling of the lower elements of the two races." 265 Displacing the community further into the north of the city would have the added outcome of removing the citizens of Greenwood from Tulsa entirely. The razing of Greenwood and repurposing the land into an industrial district, claimed the Reconstruction Committee, would also improve the views enjoyed by passengers aboard the Frisco Railroad as it approached the city from the Northwest. This would prevent Tulsa visitors from being subjected to what many whites in South Tulsa considered the blighted image presented by Greenwood. ${ }^{266}$

The ordinance outraged black Tulsans and even some whites, prompting speculation that the Riot had not been a spontaneous act of white vigilante violence, but a planned attack to facilitate the clearance of Greenwood. In a letter to the Tulsa World, one citizen wrote: "Some plot is it not? Could it be possible that such a scheme could be

${ }^{265}$ Chapman, "The Nightmare of Dreamland."; Ellsworth, Death in a Promised Land, locs. 1619, 1402-1411.

${ }^{266}$ Hirsch, Riot and Remembrance, loc. 2052. 
pre-meditated and pre-arranged? We have read of such means being used to acquire the Indian lands in the early days of this great country of ours. Could it be possible? Very likely it could." ${ }^{267}$ Director of the Red Cross, Maurice Willows, echoed this suspicion, expressing with conviction that, "This was NOT a RIOT, as some of the town papers called it in their screaming headlines of the next day. It was a well-planned, diabolical ouster of the innocent negroes from their stamping grounds." ${ }^{268}$

As with the Riot itself, the white Tulsa press cultivated public opinion in favor of the land grab. According to Willow's December 31, 1921, Red Cross report summary, "[press] activities revolve around the creation of a public sentiment which would force the negros to rebuild in a section somewhere outside the city limits." ${ }^{.269}$ Indeed, just three days after the Riot, the editor of the Tulsa Tribune, Timothy Titcomb, wrote an editorial in which he proclaimed:

The Tulsa Tribune makes no apology to the Police Commissioner or to the Mayor of this city for having pled with them to clean up the cesspools in this city. Such a district as the old "Niggertown" must never be allowed in Tulsa again. It was a cesspool of iniquity and corruption. ${ }^{270}$

Less than a month later, Titcomb's personal secretary, Amy Comstock, reiterated her boss's opinion in an article she wrote for the nationally distributed magazine, The Survey.

In the article, Comstock wrote about Tulsa's "newness" and how its relative inexperience at being a city "excuses it to some modified extent for its failures," the 'failure' being the TRR for which Tulsa was receiving much unfavorable press.

\footnotetext{
267 Ibid.

${ }^{268}$ Maurice Willows, “Willows' Personal Account," in Hower, Angels of Mercy, 115. ${ }^{269}$ Maurice Willows, "Disaster Relief Report," in Hower, Angels of Mercy, 145.

270 Timothy Titcomb, "It Must Not be Again," Tulsa Tribune, June 4, 1921.
} 
Comstock explained that "In the hurried construction of Tulsa that section which was known as "Niggertown" was pretty much neglected" and before it was burned to the ground, visitors to Tulsa who rolled into town on the Frisco railroad would have encountered an "offensive sight."271 Greenwood was the first thing people saw when coming into Tulsa on the Santa Fe Railroad.

Comstock described Greenwood as being comprised of "improvised shanties [that] abounded with out-houses standing on stilts, and yards in conspicuous disorder." Rationalizing the destruction she witnessed a month earlier as the Riot raged outside her downtown office in the Tribune Building, Comstock explained why it was in Tulsa's benefit that Greenwood be destroyed: "It was the sordid and neglected 'Niggertown' that the crooks found their best hiding place. It was a cesspool of crime $[\ldots]$ a constant menace to the health of the city."272 Comstock argued that converting the "ash-covered acres" of Greenwood into a "warehouse district" would be a better use of the land. According to Comstock and Tulsa city officials, this was preferable to African Americans rebuilding and repopulating their former neighborhood. Instead, suggested Comstock, they could use the money they made from selling their decimated land to move elsewhere and rebuild. ${ }^{273}$

The community of Greenwood believed otherwise and, even though the city would not sanction them doing so while the proposed restrictive zoning ordinance loomed, began rebuilding efforts in Greenwood. B.C. Franklin later recalled in his

271 Amy Comstock, “Another View of the Tulsa Riots," Survey, July 2, 1921, 460.

272 Ibid.

${ }^{273}$ Ibid. 
memoirs that some were "arrested a dozen times" while trying to rebuild. ${ }^{274}$ Residents prepared to fight once again for their homes, businesses, and lives. They persisted in rebuilding not only because they needed rooves over their heads, but also as an act of resistance.

Spearheaded by B.C. Franklin's law firm - the offices of which were destroyed in the fires of the Riot - the Greenwood community galvanized to oppose the land grab. Franklin and two other African American attorneys, I.H. Spears and T.O. Chappelle, reopened their law office in a tent in Greenwood where they worked to strike down the prohibitive zoning ordinance. One week after the Riot, Franklin, Spears, and Chappelle filed an injunction against the city to "enjoin and prohibit it from enforcing the ordinance." 275 They argued that "to enforce such an ordinance would be equivalent to confiscation of property without due process," which would make the city "a party to a conspiracy against [the people of Greenwood] to despoil them of their property." On September 1, 1921, they won the lawsuit. The Oklahoma Supreme Court struck down the ordinance, ruling that it "constituted an invalid taking of property without due process of law." 276 This was a significant win, albeit a bittersweet one. While African Americans were now legally permitted to rebuild within their neighborhood, it was unclear where the money would come from to pay for construction costs. Insurance companies presented another, more persistent barrier to rebuilding.

${ }^{274}$ Franklin, My Life and an Era, 199.

275 Ibid, 200.

276 Ibid. 


\section{Conclusion: "They Fought Like Tigers."}

It is important to distinguish between the four acts of violence that comprise the TRR because a close inspection reveals that these were not spontaneous acts - although they may have begun that way. Tulsa city officials, white lawmen, members of the Ku Klux Klan and private citizens took what began as a riot and used it as an opportunity organize and engage in war with black Tulsans, who-although they "fought like tigers,"-were outnumbered, outmaneuvered, and outgunned. ${ }^{277}$ It was not the riot at the courthouse or the battle at the railroad tracks that destroyed Greenwood, which is what later insurance claim denials (and, decades later, denial of reparations for TRR survivors and their descendants) were predicated upon, but instead it was the massacre and the land grab — which were orchestrated by city leaders in the weeks following the Riot — that caused Greenwood to fall. Taken altogether, these four acts amounted to the second wave of violence: the Tulsa Race Riot of 1921.

Many blacks left Greenwood after the TRR and in the face of the attempted land grab. Mozella Franklin Jones, who was the daughter of Buck Colbert Franklin, recalled that this was because "many were just disgusted, you know just disgusted, didn't see how they could start over again and they just left." 278 Those who stayed spoke of the Greenwood rebuilt in the wake of the Riot as possessing a "Phoenix-like" quality, its

277 Hirsch, Riot and Remembrance, locs. 1444-1449.

${ }^{278}$ Mozella Franklin Jones, interview by Carol Minshall, January 16, 1980, Junior League of Tulsa Oral History Interviews, Tulsa City-County Library, Tulsa, Oklahoma, accessed January 12, 2017, http://cdm15020.contentdm.oclc.org/cdm/ref/collection/p15020coll10/id/569/. 
construction an act of defiance towards those living in South Tulsa. ${ }^{279}$

279 Juanita Alexander Lewis Hopkins quoted in Hannibal B, Johnson, Black Wall Street: From Riot to Renaissance in Tulsa's Historic Greenwood District (Eakin Press, 1998), loc. 1589. 


\section{Chapter Three}

“Equally Strange and Hostile Places": From Rebuilding to Relocation, 1921-1980s

\section{Introduction: The Third and Fourth Waves of Violence}

After earlier waves of violence — segregation at statehood and the TRR - the landscape and community of Greenwood weathered ensuing waves of violence. The third wave came in the form of economic disinvestment facilitated by local and national governmental authorities. The fourth wave took the form of urban renewal-slum clearance, expressway building, and remote housing projects. These waves of violence are not the last black Tulsans faced, but they are the last that this thesis will cover. Working in tandem, they achieved the goal of displacing Tulsa's African American citizens from their close-in historic neighborhood and economic business center, splintering the residents into less visible and more remote pockets of community further into the city's north.

\section{Denial of Insurance Claims: "We had to save our own."}

After the Riot, Greenwood residents became refugees in their own community. B.C. Franklin remembered that there was "not a negro dwelling-house or place of business" where once there had been many. ${ }^{280}$ "Negros who yesterday were wealthy, living in beautiful homes and in ease and comfort, were now beggars, public charges,

${ }^{280}$ Franklin, My Life and an Era, 197. 
living off alms." ${ }^{281}$ One reporter wrote that it "resembled a soldier's camp in war." ${ }^{282}$ The Red Cross, which was active in relief efforts from June 1, 1921 through December 31 of that same year, erected tents to house some of the refugees in the former residential section of Greenwood. Other residents improvised, building shanties and structures on the tamped down ashes where their homes once stood. The Red Cross also offered to pay for the train tickets of those who wanted to leave Tulsa. ${ }^{283}$ Many made that choice, while those who stayed were eager to rebuild.

During 1921, Tulsans suffering losses because of the Riot filed 1,400 lawsuits for over $\$ 4$ million in property loss. ${ }^{284}$ However, because most of the insurance policies held a clause that protected against "'riots, civil commotion' and the like," and the grand jury cleared the city of Tulsa of all responsibility for the Riot, insurance companies refused to pay out on the claims of people who lost property in Greenwood. ${ }^{285}$ This meant that private citizens who incurred property loss would bear the entire cost of rebuilding. Franklin, Spears, and Chappelle filed dozens of lawsuits against insurance companies, but no recovery was possible in "fully 95 percent of the cases." ${ }^{286}$ This affected whites, many of whom owned properties in Greenwood, as well as African Americans.

Even though both whites and blacks incurred economic losses during the TRR, since property damages were concentrated in North Tulsa, area residents experienced a

\footnotetext{
281 Ibid.

${ }^{282}$ George W. Buckner, "Second View of City of Ruins," St. Louis Argus, April 21, 1922. Buckner was a representative of the National Urban League.

${ }^{283}$ Ellsworth, Death in a Promised Land, locs. 1233-1238

284 Ibid, locs. 1172-1178.

${ }^{285}$ Franklin, My Life and an Era, 249.

${ }^{286}$ Ibid.
} 
disproportionate strain on their economy. This is because, while whites were able to secure loans from banks and traditional lending institutions, most blacks could not and, consequently, much of the money for rebuilding was on credit with exorbitant interest rates. New buildings, many of which were erected in the footprints of their burned-out predecessors, were "going up 'on paper." 287 During a time when top wages earned by Greenwood residents ranged from $\$ 5$ to $\$ 10$ per week, building contractors charged price-gouging construction rates of $\$ 12.00$ a day. ${ }^{288}$ Greenwood residents seeking to rebuild had to take out credit with these builders, who often charged exorbitant interest rates. First burned out during the Riot, the lack of monetary accessibility extended to Tulsa's African American residents meant that they then underwent an economic freezing out. The economic devastation of the community in Greenwood following the destruction of the TRR is something that reverberated within Tulsa's black community for generations to come. This was the third wave of violence.

Greenwood residents and some white Tulsans blamed the city for letting the extreme violence and destruction of the Riot happen. Some, like Charles Wickham—an African American doctor from Greenwood—filed claims against the city of Tulsa for negligence during the TRR. A committee consisting of a Tulsa city attorney, a local private attorney, and a lawyer from East St. Louis reported that unless they could find specific negligence, the city of Tulsa was not liable for "an unlawful uprising of Negroes," stripping whites of any culpability and placing the blame for the Riot and its

${ }^{287}$ Buckner, "Second View of City of Ruins."

${ }^{288}$ Buckner, "Second View of City of Ruins." 
destruction entirely on Tulsa's black citizens. ${ }^{289}$ In August of 1921, the committee concluded that—even though Police Chief Gustafson was convicted of negligence during the TRR — the city had not been negligent. These suits continued through the mid 1930s; however, no Riot victim ever successfully sued the city or received any insurance claim money. ${ }^{290}$ Greenwood resident and Riot survivor Mabel Little recalled of that time, "We had to save our own, use what small means we had, and cooperate together $[\ldots]$ there was no other choice. ${ }^{, 291}$ Without help from the city of Tulsa and without receiving any insurance claim money, brick by brick, building by building, the citizens of Greenwood rebuilt their neighborhood.

\section{Rebuilding After the Riot: "Proof in wood and brick and stone"}

Within a year of the Riot, over eighty businesses reopened in Deep Greenwood with over half of the neighborhood's churches holding worship services. ${ }^{292}$ For the community, the destruction of their churches was tantamount to the desecration of a vital and sacred space. As they worked to recover from the TRR, the ruins of their churches stood as a persistent and glaring tribute to the racial discord that was still pervasive in Tulsa, and the unfathomable violence perpetrated upon their community during the Riot. ${ }^{293}$ The remains of Mount Zion and other churches in Greenwood symbolized not

\footnotetext{
${ }^{289}$ Hirsch, Riot and Remembrance, locs. 2099-2018.

290 Ibid.

${ }^{291}$ Little interview in Gates, They Came Searching, 171.

292 Johnson, Black Wall Street, locs. 1589-1594.

${ }^{293}$ Hirsch, Riot and Remembrance, loc. 2732.
} 
only the Riot, but perhaps more importantly, they stood for the defiance, resiliency and determination of the congregation and community.

The successful efforts of citizens to reclaim their land and rebuild gave the neighborhood new notoriety and the residents a restored pride of place. Rebuilding became "the subject of most favorable comment all over the country," in particular by the black press and other African American organizations such as Tulsa's Colored Citizens Relief Committee and East End Welfare Board (EEWB), an activist organization formed by black Tulsans in response to the needs of their community in the wake of the Riot. ${ }^{294}$ In her book Events of the Tulsa Disaster, Mary E. Jones Parish wrote of the EEWB "They looked after the needs of the people both physically and legally $[\ldots]$ These men worked faithfully and have fought many battles for their fellowman." ${ }^{295}$ In a letter to the Red Cross the EEWB extoled the courage of Greenwood's residents as they "withstood repeated attempts of the city administration to deliver the 'burned area' over to certain land grafters." They lauded the swiftness with which citizens were rebuilding their neighborhood "in most instances, better than before," as "proof in wood and brick and in stone of the black man's ability to make progress against the most cunningly planned and powerfully organized opposition. ${ }^{{ }^{296}}$ George W. Buckner of the National Urban League

\footnotetext{
294 Ellsworth, Death in a Promised Land, locs. 1320-1325.

295 Parrish, Events of the Tulsa Disaster, 20.

296 Buckner, "Second View of City of Ruins."

In Greenwood, the Red Cross cared for the wounded, set up tents to house the refugees, paid people's train fare if they wanted to leave Tulsa, and advocated for the residents of Greenwood that the Riot was not a spontaneous act of violence, but a planned attack in order to facilitate the land grab. Maurice Willows, the director of the Red Cross, was thought so highly of by the residents of Greenwood that they later named a hospital after him. Today, a statue of Willows stands in John Hope Franklin park in historic Greenwood as part of the Tulsa Race Riot memorial, which was erected in 2010.
} 
wrote in the St. Louis Arugus, a black-owned and operated newspaper, that Greenwood residents felt "bound to their home." He attributed their rebuilding success to "the spirit exhibited from the beginning by the Tulsa Negroes," which he said "should be the pride of the whole race. ${ }^{297}$ The rapidity with which the people of Greenwood were able to rebuild was due in part to the culture of interdependence that was also instrumental in the settling of Greenwood. The community's defiance in the face of the destruction of the Riot and the attempted land grab by Tulsa city planners earned Tulsa's all-black district a nationwide reputation of being a place and a people that were not to be conquered.

\section{Commerce and Community: "A net of intertwined, loving arms"}

In 1925, Greenwood hosted a meeting of the National Negro Business League (NNBL) - an organization that worked to promote the economic development of African American businesses and communities nationwide. ${ }^{298}$ Many Greenwood residents saw this event as an indication of the resurgence of their community and their economy. B.C. Franklin took the NNBL event as a sign that things had finally settled down enough to bring his family to join him in Greenwood. ${ }^{299}$

Originally intending to move his family to Tulsa in 1921, Franklin—having put the move on hold indefinitely after the TRR — relocated his wife and children to Tulsa from Rentiesville in $1925 .{ }^{300}$ His son, John Hope Franklin, was ten years old when he

${ }^{297}$ Ibid.

298 Gates, They Came Searching, 273.

${ }^{299}$ Also of note for 1925, that summer Tate Brady — despondent over his son's death and hounded by legal investigations into his vice activity - committed suicide by shooting himself at the dining room table of the family's home in Tulsa.

${ }^{300}$ Franklin, My Life and an Era, 367. 
arrived. ${ }^{301}$ The ruins of Mount Zion and several other African American churches left an enduring impression on young Franklin, who later recalled, "They would go up to a certain point — and then flat. No superstructure, no arches, no towers, no belfries. ${ }^{.302}$ In John Hope Franklin's mind, the salvaged ruins of Mount Zion and other black churches were a testament to "Man's inhumanity to man," and, growing up in post-Riot Greenwood, he learned much about the country's racial divide as it was embodied in the landscape. ${ }^{303}$ Moving through Greenwood's streets, interacting with its buildings, drove home the disparity between North and South Tulsa, highlighting the city's racial divide. John Hope Franklin cites the most pronounced difference as being evident in the towering and imposing white churches of South Tulsa, such as Boston Avenue Methodist, and the wrecked houses of worship of Greenwood in North Tulsa. ${ }^{304}$ By the 1930s, residents had rebuilt most of the businesses in Deep Greenwood. B.C. Franklin's daughter, Mozella Franklin Jones, recalled that by this time Greenwood was "more alive" than ever. "The economy," she remembered, "was just booming in north Tulsa." ${ }^{305}$ This she attributed not only to the tenacity and resilience of black

${ }^{301}$ John Hope Franklin grew up to be a historian, his scholarship helping to redefine the black American experience.

${ }^{302}$ Hirsch, Riot and Remembrance, loc. 2746.

${ }^{303}$ Ibid.

${ }^{304}$ Hirsch, Riot and Remembrance, loc. 2741. The rebuilding of Mount Zion was a glacial process that spanned 31 years. Efforts to rebuild were first stalled by the debt remaining from the 1921 construction, as the insurance on the church had a riot clause which rendered their claim on the destroyed building worthless. The debt became a divisive issue among the congregants - some believed they should pay it while others did not and nearly led to the dissolution of the church. On Sunday, October 21, 1952, after years of sustained rebuilding and fundraising efforts (total rebuilding costs amounted to $\$ 300,000$ ) dedication services were held for the newly reconstructed Mount Zion Baptist Church.

${ }^{305}$ Jones, interview. 
Tulsans, but also, to an unintended consequence of segregation. Like in pre-Riot Greenwood, African Americans could earn money anywhere in town, but they could only spend it where they lived in North Tulsa. "We had everything that was needed [and our] needs were met in [our] own community," recalled Mozella. ${ }^{306}$ Remaining in their neighborhood enabled Greenwood residents to maintain the culture of interdependence which helped them not only to rebuild but also to sustain their economy. Even as they were disinvested from mainstream lending and banking organizations by the practice of redlining, the continuity of place made it possible for the community to uphold traditions and practices that had long buttressed both their social fabric and their economy, as the two were intertwined.

Businesses in Deep Greenwood carried on the tradition of pre-Riot Greenwood's mixture of commerce and community. Located in Deep Greenwood, the Williams Drug Store was known by people in the neighborhood as "a Social Center." 307 It offered something for everyone with a soda fountain for teenagers, beauty products, home goods, and "medicine on credit for the elderly." 308 Owner Dr. Lloyd Hume Williams Jr. recalled that Sundays were the store's busiest day: "All generations of North Tulsans converged on the drugstore on Sundays after church. They came from Mt. Zion, Vernon AME, Morning Star, Paradise Baptist, and other churches in the area. [...] Oh it was a lively, hectic, wonderful sight to see!" ${ }^{309}$ Oklahoma State Representative Don Ross frequented

\footnotetext{
306 Ibid.

307 Gates, They Came Searching, 228.

308 Ibid.

${ }^{309}$ Dr. Lloyd Hume Williams Jr. interviewed by Eddie Faye Gates in Gates, They Came Searching, 230.
} 
the Williams Drug Store as a teenager. Ross recalled how the proprietors provided Greenwood's youth with "somewhere to go and something worthwhile to do." ${ }^{310}$ Ross attributes much of his success as an adult to people like Dr. Williams keeping him and his friends out of trouble. The Williams Drug Store was one of three on the same block during the 1940s, a time period that is often touted as the heyday of Greenwood. ${ }^{311}$

Like pre-Riot businesses in Deep Greenwood, the Williams Drug Store served as both a community gathering space and "a sort of a community social service agency," continuing the tradition of mixing business with community that was integral to the economic success of pre-Riot Greenwood. ${ }^{312}$ Jeanne Goodwin, wife of E.L. Goodwin who founded the Oklahoma Eagle newspaper-a black Tulsa newspaper which has its roots in the Tulsa Star - called the community that existed in post-Riot Greenwood "a net of intertwined, loving arms." ${ }^{\prime 313}$ The proximity to friends and relatives enabled a culture of interdependence to continue to strengthen the interwoven fabric of community and economy in Greenwood.

By remaining in place, the continuity that residents were able to maintain after the near total destruction of the TRR allowed them to preserve community ties, look out for one another, and support their own economy. By 1942, the 35 blocks of Greenwood contained 242 black-owned and operated businesses and, up until the late 1950s rivaled, its pre-Riot heyday. ${ }^{314}$ Residents often refer to this as a period of renaissance for those

${ }^{310}$ Don Ross interviewed by Eddie Faye Gates in Gates, They Came Searching, 232-233.

311 Dan Rutherford, "The Glory of Greenwood," Tulsa World, March 10, 1997.

312 Gates, They Came Searching, 228.

313 Jeanne Goodwin interviewed by Eddie Faye Gates in Gates, They Came Searching, 90. 
who lived there as the economic and cultural center abounded with shops and businesses owned and patronized by people who lived in the surrounding neighborhood. However, much like before the TRR, this was less so the case for Greenwood's residential areas.

\section{Slum Clearance in Greenwood}

While businesses in Deep Greenwood were doing well, many of the residential areas that radiated north from there suffered from poverty, dilapidation, and a lack of taxfunded infrastructure. In 1940, Dr. Charles Bate moved to Tulsa and began practicing medicine. He recalled in an oral history interview that during the 1940s:

There were about 20,000 blacks in an area about less than four square miles. I had never seen living conditions in a city like they were in Tulsa. [There were] 25 foot lots with 3 houses on one lot. And you'd have to go through the first two houses to get into the last house. There were outdoor privies everywhere. And none of the streets were paved in the Negro area of Tulsa. ${ }^{315}$

Just as in pre-Riot Greenwood, the city of Tulsa was slow to provide basic infrastructure such as garbage, sewage lines, and paved roads. In certain areas— such as North Tulsa— the city neglected to provide these services altogether. ${ }^{316}$

For residents, the lack of infrastructure and access to capital made it next to impossible for people to maintain their properties. Federal discriminatory housing legislation, policies, and practices - in particular the Home Owner's Loan Corporation (HOLC) beginning in 1933 and the Federal Housing Administration (FHA) the following

\footnotetext{
${ }^{315}$ Dr. Charles Bate interviewed by Cherie Poyas for the Junior League of Tulsa, May 6, 1980, Tulsa City-County Library, accessed August 15, 2016, http://cdm15020.contentdm.oclc.org/cdm/ref/collection/p15020coll10/id/140.

${ }^{316}$ Hirsch, Riot and Remembrance, locs. 670-674.
} 
year-reinforced local customs. ${ }^{317}$ The purpose of HOLC was to refinance the mortgages of homeowners facing default or foreclosure during the Great Depression and to make a recommendation for or against the granting of loans in specific areas. The recommendation depended on the HOLC's appraisal of neighborhoods and properties. HOLC appraisers considered the age, construction quality, and type of homes in each neighborhood as well as their proximity to positive and adverse influences - the closeness of churches and schools as opposed to factories and vice districts. They also took into account the kinds of people who lived there, surveying residents as to their income, occupation, and ethnicity. If a neighborhood was newer, had good construction quality, was close to schools and churches, had restrictive covenants and all-white residents, HOLC appraisers gave it a high rating, approving the granting of loans for home improvements and new-builds within the area. If the neighborhood was aging, its homes constructed of shoddy materials or falling into disrepair, located close to adverse influences, had expired, close to expiring, or no restrictive covenants at all—or if even a

317 See Richard Rothstein, The Color of Law: A Forgotten History of How Our Government Segregated America (New York, London: Liveright Publishing Corporation, 2017); Kevin Fox Gotham, "Urban Space, Restrictive Covenants and the Origins of Racial Residential Segregation in a US City, 1900-50," International Journal of Urban and Regional Research, 24:3 (September 2000); Mindy Thompson Fullilove and Rodrick Wallace, "Serial Forced Displacement in American Cities, 1916-2010," Journal of Urban Health: Bulletin of the New York Academy of Medicine, 88:3 (2011); Douglas Massey and Nancy Denton, American Apartheid: Segregation and the Making of the Underclass, (Boston: Harvard University Press, 1993); Roger Biles, From Tenements to the Taylor Homes: In Search of an Urban Housing Policy in Twentieth-Century America, (Penn State Press, 2010); and Kenneth T. Jackson, Crabgrass Frontier: The Suburbanization of the United States, (Oxford University Press, 1987, Kindle edition). 
single black family lived within the boundaries of the neighborhood-HOLC appraisers gave it a low rating and no loans would be approved in that area. ${ }^{318}$

From information gleaned in these surveys, HOLC appraisers created Residential Security Maps, which is where the process of redlining originated. ${ }^{319}$ Redlining was intended to delineate areas that were too high risk for real estate investment, which were unfailingly older neighborhoods where non-white residents lived—neighborhoods like Greenwood. As was the case nationwide, Tulsa's HOLC assessor applied their colored pencil decisively to the city's neighborhoods. In so doing they recommended some areas for investment while disinvesting others. The assessor decided that neighborhoods like Riverside Drive and Florence Park in South Tulsa were among the city's "Best" areas, so colored them green. Other South Tulsa neighborhoods, Swan Lake and the University of Tulsa, decided the assessor, were "Still Desirable," so colored those a deep shade of blue. Bordering neighborhoods, such as Cherokee Heights and Fairmont were, according to the assessment rubric, "Definitely Declining," and so the assessor colored them yellow. This is likely because they abutted Tulsa's "Hazardous" neighborhoods, Greenwood and all of North Tulsa, to which the assessor applied a saturated red. Tulsa's HOLC assessor colored everything from the Frisco Railroad tracks that divided the north side of the city from the south, up through Greenwood, past Pine Street, and all the way to Apache Street in a swath of red. In so doing they disinvested the entire area. ${ }^{320}$

\footnotetext{
318 Ibid.

319 Jackson, Crabgrass Frontier, locs. 3177-3791.

${ }^{320}$ Home Owners Loan Corporation, Tulsa Security Map, exact date unknown, map held in possession of author. I was able to find the HOLC Security Map for Tulsa by emailing the people at Mapping Inequalities (https://dsl.richmond.edu/panorama/redlining/\#loc=4/36.71/-96.93\&opacity $=0.8$ ) and
} 
Greenwood was not alone in this predicament as the story is a familiar one for communities of color across America. The HOLC appraisal system and maps, which were accessible to banking and lending institutions, were eventually adopted and absorbed by the Federal Housing Administration, which has its inception in the Housing Act of 1934. This ensured that the HOLC's standards of "racial worth in real estate" were bureaucratized and applied on a national scale with the full weight of government sanctioned racial discrimination in housing behind them. ${ }^{321}$ This influenced how neighborhoods developed over time by affecting the ability of people of color to qualify for home loans. Additionally, with the U.S. Supreme Court ruling segregation unconstitutional in 1954, Tulsa saw desegregation, while a critical gain for civil rights, contribute to the erosion of Greenwood's economy. As desegregation served to broaden opportunities for African Americans nationally, in Greenwood and elsewhere it also ushered in a period of blight in the houses and buildings around them. One former resident remembers this as a time when city government officials began "removing and relocating people and condemning buildings" in the name of "renewal." 322

With the economy hobbled by disinvestment, Greenwood began to enter into a period of slow decline. In answer to this, Tulsa aimed to clean up the neighborhood by tearing much of it down, using the provisions of Title I of the Housing Act. Title I allotted federal funds for the seizing and clearance of large parcels of land where slum

asking if they happened to have it laying around. Luckily, they did and were kind enough to send me a digital scan. They let me know that they will be uploading it this summer, but until then, I have added it to the appendix here. The exact date of the map is unknown, but they said that it was most likely created between 1933 and 1940.

${ }^{321}$ Massey and Denton, American Apartheid, 52.

322 Jones, interview. 
properties existed, slating them for redevelopment. While Title I was intended to help rid cities like Tulsa of their inner city slums, the federal urban renewal program, which fell under the umbrella of Title I, was vague in its goals and definitions; consequently, there was perpetual debate and argument over how the program should be applied. ${ }^{323}$ That it was meant to promote the betterment of the city was clear, but the devil was in the details with what exactly 'renewal' meant. ${ }^{324}$

Greenwood resident and Riot survivor Jobie Elizabeth Holderness described what urban renewal meant for North Tulsa: "The black community lost some valuable things in the process. Urban renewal not only took away our property, but something else more important - our black unity, our pride, our sense of achievement, and history." ${ }^{325}$ Slum clearance enacted under Title I meant that large swaths of land were cleared, the landscape of the neighborhood was reduced to rubble, and people were displaced further into the north of the city. For many African Americans who lived through the 1921 Riot, or for those who grew up hearing about it, slum clearance and urban renewal evoked remembrances of the first time Greenwood was destroyed at the hands of white Tulsans. While the prohibitive zoning ordinance city officials attempted to pass after the Riot failed, midcentury processes of urban renewal successfully solidified segregation in Tulsa's public spaces by destroying much of the physical characteristics of the neighborhood - a government assisted and sanctioned act that made it impossible for most people to remain in place. In displacing black Tulsans the city of Tulsa also

\footnotetext{
323 Ibid.

${ }^{324}$ Ibid, 444.

${ }^{325}$ Gates, They Came Searching, 106-107.
} 
disrupted their continuity — their history, shared identity, and the culture of interdependence that they had for so long maintained. In an interview, Juanita Hopkins explained, “There's a saying in the neighborhoods, 'It's not urban renewal, it's urban removal." ${ }^{326}$ The saying in Greenwood was one repeated by African Americans nationwide with many calling it "negro removal." The widespread demolition of neighborhoods like Greenwood and the relocation of area residents substantiates their claim. $^{327}$

\section{Interstate Highways: The Crosstown Expressway}

While urban renewal and slum clearance chipped away at the fabric of community and the landscape in Greenwood, Mozella Franklin Jones remembered that it "really began to erode when the freeway came through. ${ }^{.328}$ With the passage of the U.S. FederalAid Highway Act in 1956, government officials, city planners, downtown developers, highway promoters, and builders employed the new interstate highway system as an agent of destruction for blighted urban areas. The Federal-Aid Highway Act propelled massive efforts of demolition as they routed highways through cities. ${ }^{329}$ While the federal government provided the majority of funding for the construction of interstate highways, local Tulsa officials and the Oklahoma State Highway Department selected the path of their piece of the interstate, which meant that they could specifically design their local

\footnotetext{
326 Juanita Alexander Lewis Hopkins quoted in Johnson, Black Wall Street, loc. 1589.

${ }^{327}$ Massey and Denton, American Apartheid, 56

328 Jones, interview.

${ }^{329}$ Francesca Russello Ammon, Bulldozer: Demolition and Clearance of the Postwar Landscape (New Haven: Yale University Press, 2016, Kindle edition), 8.
} 
highways to carry out regional "race, housing, and residential segregation agendas." ${ }^{330} \mathrm{In}$ this way, the Interstate Highway System functioned in Tulsa and nationwide to reclaim and repurpose prime urban real estate. ${ }^{331}$

Planning began in 1957 with Tulsa city planners electing to have the Crosstown Expressway—the northern section of the city's Inner Dispersal Loop—run straight through the core of Deep Greenwood. ${ }^{332}$ In building this section of the expressway, local government officials in Tulsa were able to use interstate highway construction to carry out the longstanding agenda of removing their African American citizenry from the close in area next to downtown to less visible areas further into the city's north. ${ }^{333}$ Once completed, the expressway unfurled through the core of Deep Greenwood, effectively creating a bulwark between North and South Tulsa while bisecting and eviscerating Greenwood's economic and cultural center in the process. ${ }^{334}$

\section{Urban Renewal Housing Projects}

As the Crosstown Expressway shot through the heart of their business district, many Greenwood residents relocated north of Pine Street, the northernmost boundary of Greenwood. In 1921, this was the area the zoning ordinance would have displaced black Tulsans to. In 1961, it was this same area that Tulsa city planners were eying for the location of the Seminole Hills Demonstration Housing Project, Oklahoma's first urban

330 Biles, From Tenements to the Taylor Homes, 299.

${ }^{331}$ Hirsch, Riot and Remembrance, loc. 2960.

332 "Wooton Lists Most Needed City Projects: Expressways, Streets, Sewers, City Hall Are Among 24 Priority Jobs,” Tulsa Tribune, July 26, 1957.

333 Biles, From Tenements to the Taylor Homes, 299.

334 Hirsch, Riot and Remembrance, loc. 2934. 
renewal housing project. ${ }^{335}$ In early February, 1961, Leemon Nix, the chairman of the Tulsa Urban Renewal Authority (TURA), met with a group of city planners in South Tulsa to discuss the survey of an area in the far north side of town for the future site of the Seminole Hills housing project. ${ }^{336}$ Bound by Utica and Peoria Avenues to the east and west and Virgin and Reading Streets to the north and south, Tulsa's Seminole Hills urban renewal area encompassed ninety-one acres of the city's north side on which some 167 inhabited residential properties already stood. The proposed site was in one of Tulsa's slum clearance areas, the existing homes were identified by TURA as being substandard, lacking in structural integrity and cleanliness. The planners proposed razing eight city blocks to make way for the new housing project, part of the federal housing program initiative overseen by the U.S. Department of Housing and Urban Development (HUD). ${ }^{337}$

In 1962, residents of the Seminole Hills urban renewal area, many of whom had relocated there from Greenwood after being displaced by slum clearance and expressway building, caught wind of the proposed housing project and began working to protect their community from once again being displaced. They protested the plan during a four-hourlong public hearing where around seventy residents "delivered emotional protests" to the plan. ${ }^{338}$ The question of why city planners wanted to displace people from their homes

335 "Urban Renewal Unit Picks Tulsa Firm for Seminole Hills Survey," Tulsa Tribune, February 2, 1961, 39.

336 “Urban Renewal Unit Picks Tulsa Firm for Seminole Hills Survey," Tulsa Tribune, February 2, 1961, 39; and "TURA Gets First Check For Buying," Tulsa World, February 28, 1963, 1.

337 Ibid.

338 "Seminole Families Protest: Tulsa OK's Urban Renewal," Tulsa World, October 20, $1962,1$. 
only to build new ones was at the root of the community's protest. "Why," asked one area resident, "do they want to take us from our homes, put us out and put other people in them?" 339 The Tulsa Metropolitan Area Planning (TMAP) Commission explained that their reasoning lay in problems of blight.

TMAP's General Development Plan determined that blighted conditions in the Seminole Hills urban renewal area stemmed from "Inadequate original construction and overcrowding of land due to additions to original structures." ${ }^{340}$ It stated further that "the lack of any systematic and objective enforcement of basic health and sanitation codes, until the last few years, compounds these problems." ${ }^{341}$ They found that the majority of existing homes in the area were of a "frame-type construction [...] built prior to World War II," with "a large percentage of the older housing in the community [being] substandard as a result of inadequate original construction, dilapidation, overcrowding, and poor urban design." Their goal was "to give every citizen the opportunity to live and work in an atmosphere conducive to conscientious and responsible citizenship." This, states the report, could be accomplished by "the elimination of large areas of blight and a general improvement of the land use pattern." ${ }^{342}$ One area resident challenged the relevance of TMAP's proposal, arguing during the meeting that "I don't know where you get this blight. Here you're going to uproot 120 families to put in 120 more families [...]

\footnotetext{
339 Ibid

340 Tulsa Metropolitan Area Planning Commission, "Metropolitan Tulsa Program For Community Renewal: General Development Plan," Tulsa City-County Library Archives, Tulsa, Oklahoma, 1963, 139.

${ }^{341}$ Ibid.

342 Tulsa Metropolitan Area Planning Commission, "Metropolitan Tulsa Program For Community Renewal: General Development Plan," 140.
} 
in a neighborhood where they don't know anyone." ${ }^{\prime 43}$ The blighted conditions Tulsa city planners detailed in this report—and sought to mitigate with the new housing projectwas the outcome of decades of economic disinvestment and infrastructural neglect in North Tulsa on the part of the city, which was supported by discriminatory federal housing policies, banking, and real estate practices. The plan to displace families and move in new ones would, as area residents asserted, serve to further fracture and destabilize the community.

Despite community protest, in the fall of 1962, the Tulsa City Commission unanimously approved the Seminole Hills urban renewal plan and the city pledged $\$ 316,406$ in funds to put towards the Seminole Hills project. TURA officials presented homeowners in Seminole Hills - many of whom had bought their homes "on contract"with the proposal of erasing any remaining mortgage debt if they walked away from their homes, claiming they would also help displaced residents relocate and pay for costs of moving. ${ }^{344}$ Early the following year the city completed negotiations to acquire 45

343 "Seminole Families Protest."
344 "Look to Future with Confidence: Renewal Group Gratified with First Year's Results," Tulsa World, 1964. Contract selling is a predatory lending practice where real estate speculators buy up houses and sell them on contract at inflated mortgage rates to people who are unable to secure a mortgage loan from traditional banks. These people are usually minorities. Terms of these often exploitative contracts made it such that if a homeowner missed a payment they incurred service charges, which put them further behind and further in debt. In order to not fall behind on payments and risk losing their homes, many North Tulsa residents picked up extra shifts at the expense of spending time with their children and families while basic home improvements and repairs were delayed in favor of keeping up with the mortgage. Homeowners built ramshackle additions to accommodate boarders and bring in extra income. All of this coupled with a lack of services on the part of the city of Tulsa, such as bus lines and basic road maintenance, led to further conditions of dilapidation and overcrowding in the area which contributed to decades of physical and economic decline and blight in North Tulsa and other American cities. For an excellent study on contract selling and community resistance, see Beryl 
properties with a total combined value of $\$ 221,625 .{ }^{345}$ Where the displaced residents were relocated, or whether TURA made good on their promise, is unclear. President of the Tulsa Property Owners Association, Robert Shelton, alleged that people who were displaced from the Seminole Hills project "had not been found proper housing as required by law." ${ }^{346}$ A vehement opponent of urban renewal in Tulsa, Shelton called for "a full and impartial investigation," into relocation efforts in Seminole Hills. It is not clear whether the investigation ever took place. ${ }^{347}$

By late March of 1964 TURA completed the purchase of all properties, clearing 100 lots of their homes. ${ }^{348}$ These lots were then sold to three Tulsa area home builders who formed a company named Seminole Hills Associates (SHA). Once they completed construction on a home, the SHA then sold it to the Home Builders Demonstration Inc. (HBD), a non-profit corporation formed and funded through a federal grant. HBD was run by a seven-member board with three of the board members appointed by city government, three by the Tulsa Home Builders Association, and one, LeRoy Thomas, chosen by the first 25 residents of the Seminole Hills project. ${ }^{349}$

Satter, Family Properties: Race, Real Estate, and the Exploitation of Black Urban America, (New York: Henry Holt and Company, 2010).

345 "City Earmarks \$316,406 For Urban Renewal Cost," Tulsa World, December 19, $1962,1$.

346 "City Okays Westbank Renewal Plan," Tulsa World, c. 1960s. This source is a newspaper clipping and whoever clipped it did not record the exact date. Instead they wrote "ca. 1961-1969."

${ }^{347}$ Ibid.

348 "Renewal Group Gratified With First Year's Results," Tulsa World, March 8, 1964, 1. "Abuses in Public Housing Expensive for Taxpayers," Tulsa World, March 20, 1964; Tom Birmingham, "Urban Renewal Has Human Side," Tulsa World, July 30, 1966, 13. ${ }^{349}$ Ibid. 
Working with Tulsa's Family and Children's Service and the University of Tulsa, the HBD selected prospective residents to live in the new Seminole Hills housing project. Those who qualified could have a combined household income of up to $\$ 7,500$ per year. Houses in Seminole Hills could be purchased on a rent-to-own basis where base payments, or rent, was $\$ 49.87$ per month. Any money the resident payed above that amount would go toward the down payment. Once the aspiring home owners amassed $\$ 300$ in their down payment funds, they were required to apply for a Federal Housing Association (FHA) insured loan. If approved, they could take out a mortgage on the home. The Seminole Hills residents were allowed five years to accrue the $\$ 300$ down payment. The HBD was to provide a project manager to help residents navigate the program, provide aid to families, and keep an eye on the properties to ensure that blight did not creep its way back in. ${ }^{350}$

In the summer of 1966 the Seminole Hills housing project was considered nearly complete with 72 of the 75 "demonstration houses" thus far built occupied by hopeful new residents. Three were empty and 10 had seen their residents evicted, one for running a whisky still out of his garage and another for "sloppy housekeeping." ${ }^{551}$ In 1967, the Tulsa Housing Authority (THA) took over the Seminole Hills housing project where there was a list of 2,200 people waiting to move into the approximately 150 units. Fearing there was too large of a gap between people's income and the amount they were paying to live in the Seminole Hills homes, the THA lowered the cap on the allowed combined household income of residents from $\$ 7,500$ to $\$ 3,900$ annually. Under this

${ }^{350}$ Ibid.; "TURA Still Supporting Housing Plan," Tulsa Tribune, 1967.

351 Birmingham, "Urban Renewal Has Human Side." 
revised plan, amenities such as air conditioning, which the previous plan had allowed for, were no longer included. TURA criticized the shoddy construction and high-density of housing in the project. Dr. Charles E. Christopher, vice chairman of TURA, expressed particular concern about future maintenance costs which, he pointed out, would be exacerbated by the low-income residents of Seminole Hills. ${ }^{352}$ North Tulsa community leaders urged TURA to consider cultivating economic diversity in the urban renewal area. Willard Vann, executive Secretary of the local chapter of the National Association for the Advancement of Colored People (NAACP), stated unequivocally that "We do not want to see a concentration of low-cost housing in one area. We do not want to perpetuate a ghetto. We do not wish to build a ghetto." ${ }^{353}$ Instead, Vann argued that unless low cost housing was dispersed more widely over the city, the area from north of the Cherokee Expressway's Inner Dispersal Loop-the historic African American community of Greenwood - all the way beyond Pine and past Apache Street to the Gilcrease Expressway would become a ghetto in fifteen to twenty years. Despite these reservations, TURA approved the project. ${ }^{354}$

Vann was right. By 1967, slum clearance, expressway building, and urban renewal programs had left Greenwood in a state of serious decline. The Seminole Hills housing project ultimately shifted the blight that Tulsa city planners sought to remove from the area abutting downtown deeper into the already blighted and overcrowded north. With the lowered income requirement necessitating scaled-back construction plans

\footnotetext{
352 "TURA Still Supporting Housing Plan."

${ }^{353}$ Ibid.

${ }^{354}$ Ibid.
} 
that utilized sub-par materials and a lack of economic diversity among residents, by 1970 , cost-cutting measures in the Seminole Hills housing project were beginning to manifest in the early stages of dilapidation. During that same year, the Model Cities Program built the first of what would eventually be 20 housing complexes within the Seminole Hills urban renewal area: the Seminole Hills Apartments. Consisting of two units-Seminole Hills I and the Seminole Hills II Annex - the apartment complex was an island in a sea of residential houses with little to no economic diversity. The 145 garden-style apartments were separated by two city blocks across the street from Booker T. Washington High School, which Tulsa city planners had relocated in 1959 to make way for the Crosstown Expressway. ${ }^{355}$

At the same time, without cultivating the economic diversity that Vann and other African American leaders in Greenwood called for, city planners destroyed the community's long-term foundation for economic sustainability by displacing them from their historic neighborhood. This decentralized and destabilized the community, contributing to social isolation and a concentration of poverty. Moreover, much of the landscape was eradicated by lumbering State Highway Department equipment—-their bulldozers and front-end loaders chewing-up mouthfuls of brick, lathe, and plaster. ${ }^{356}$

355 "Construction Criticized: Seminole Hills Project Given TURA Approval," Tulsa Tribune, 1967; Tulsa, Oklahoma Police Department, "Drug-Related Crime Problems in Public Housing," The Problem-Oriented Approach to Drug Enforcement, Bureau of Justice, Police Executive Research Forum, June 1, 1989, page 1, http://www.popcenter.org/library/unpublished/CaseStudies/131_Problem_Oriented_Appr oach_to_Drug_Enforcement_Four_Case_pdf.

356 Tom Omstead, "Money Scramble Set Off As 'Dozer Reveals Cache," Tulsa World, c. 1960s; “"Inheritance' Still Eludes Widow," Tulsa World, c. 1960s; “There's Just No Accounting Of Cash Cache," Tulsa World, c. 1960s. This series of newspaper articles reveals the story of a large cache of money that was found stashed in the walls of "the old 
With the buildings in varying states of destruction, many of the people left too, moving further into the city's north. The businesses that remained had a dwindling customer base and struggled to remain open.

One newspaper article from this period described Greenwood as "languishing," stating that many of the neighborhood's businesses were now boarded up: "Bar-B-Que signs dot the streets but the gaudy glow of restaurant signs seen in South Tulsa don't exist. Those with money, the ones who made it in the white man's world have moved out and the ones remaining, the low-income families are not big spenders. ${ }^{\circ 357}$ The entire area reportedly contained 6,175 units of substandard housing, "nine per cent of which would collapse with a well-aimed shove." ${ }^{358}$ The racial demographics of Tulsa's north side was 70 percent black with the remaining being "Indians, Mexican Americans, and disadvantaged whites." Of the people living there, 30 percent of those under the age of 21 were on welfare, over half of those over 65 were receiving "old-age assistance," and 25 percent of people over the age of 25 possessed less than an eighth-grade education. Of 13,065 arrests that took place in Tulsa, a little under half were in Greenwood and greater North Tulsa, where over 35,000 people lived. 359

Miller Hotel" in Greenwood, which the reporter described as a transient hotel. The money, amounted to around $\$ 20,000$ and was uncovered by the unsympathetic claw of a bulldozer during demolition for the Crosstown Expressway. As quickly as the money was discovered, it disappeared into the pockets of workmen and area residents. It turned out that the money was the life savings of Joe "Baggage Man" Miller who, like many Greenwood residents, did not trust banks so elected to hide his savings instead. Miller passed away without letting his wife know where he had hidden their money and she never saw a dime. Again, this is a clipping from the Tulsa World and whoever did the cutting only wrote "(1961-69)" for the date range.

357 "Model Cities," Tulsa World, December 8, 1967, 54.

${ }^{358}$ Ibid.

${ }^{359}$ Ibid. 
North Tulsa residents believed that reclaiming the cleared, close-in property that was the historic Greenwood district was their best bet for securing financial resources towards bolstering their economy. With the completion of the Crosstown Expressway in April 1973, black Tulsans became increasingly concerned that urban renewal would push them even further north. ${ }^{360}$ Ray Freeman, Project Director of the North Tulsa Business Development Center, spoke to these concerns, stating that, "no one has been really sincere in developing North Tulsa," in particular, the area stretching from the central business district to Pine Street. Freeman believed this lack of development was indicative of the city's plan to push African Americans further to the North away from the city center. Greenwood Chamber of Commerce President, Wilbert Collins echoed this belief, explaining that one of the most significant problems facing North Tulsa was the redlining that made it next to impossible to get financing in the area. ${ }^{361}$ Former Director of the Seminole Hills Demonstration Housing Project, Leroy Thomas, explained that while he wanted a home in North Tulsa, banks would not give loans on properties north of Admiral. "So," he said, "I literally built it myself." Thomas added, "I don't shop in South Tulsa. I've never bought as much as a handkerchief or shoestring in Southland." ${ }^{\prime 362}$ Most black Tulsans stayed in the North which, coupled with many of them being displaced by processes of urban renewal, led to an increase in demand for public housing.

By 1978, the city built four other low-income housing projects within a two-mile radius of the Seminole Hills Apartments: Morning Star, Vernon Manor, Comanche Park,

\footnotetext{
${ }^{360}$ Hall, "North Tulsa," 13-14, Ruth Sigler Avery Tulsa Race Riot Archive, Oklahoma State University Tulsa Special Collections and Archives, Series 2, Research Box 6. ${ }^{361}$ Ibid, 15.

${ }^{362}$ Ibid.
} 
and Osage Hills. All were north of Pine Street, with Vernon Manor, Comanche Park, and Osage Hills located north of the Gilcrease Expressway. The housing projects were all situated between two and four miles away from Deep Greenwood. ${ }^{363}$ This separation of space hampered the ability of the formerly tight-knit community to maintain the culture of interdependence that was a mainstay of life when most of them lived within Greenwood - an area of four-square miles. ${ }^{364}$ By decentralizing the community, Tulsa city planners destroyed one of the core components of the community's previous success with building and then rebuilding Greenwood after the TRR. The proximity to neighbors, friends, and relatives that had enabled the community to maintain continuity through interconnectedness and a culture of interdependence. By removing black Tulsans from their historic home and displacing them into satellited housing projects, the city of Tulsa engineered an invisible barrier of distance. This made it difficult to maintain the relationships that were central to the survival and vibrancy of the community. The destruction of their neighborhood with processes of urban renewal also erased much of their history, as those physical landmarks were the touchstones of their memories.

In 1978, Riot survivor and acquaintance of Dick Rowland, Robert Fairchild, retired from thirty years of working in the Parks Department as a city health worker. He lived about a half a mile away from the Seminole Hills Apartments. As he reflected on the legacy of the Riot during an oral history interview, he said that whites in Tulsa "always had some misgivings about letting the riot develop" because they had not

${ }^{363}$ See appendix for map of housing projects in relation to historic Greenwood neighborhood.

${ }^{364}$ Hirsch, Riot and Remembrance, 583. 
foreseen "the scars that would evolve as a result of the riot." ${ }^{365}$ One of the "basic breakdowns of the community" in Greenwood and North Tulsa in the decades that followed the Riot, according to Fairchild, was that “we've had leadership, but we've never been able to exercise it." Of blacks in Tulsa both before and after the Riot, Fairchild said "We've always been as the crabs in the bucket."

By 1980, the Tulsa Housing Authority had constructed or purchased a total of 2,434 units of public housing mostly located in North Tulsa to meet the increasing demand. Close to a decade later, the rate of crime in the Seminole Hills Apartments exceeded that of the occupancy rate. Putting this statistic into context, a person living in one of the apartments had over a 100-percent chance of becoming the victim of a crimeas the apartment complex alone possessed the highest incidence of crime in all of Tulsa. ${ }^{367}$ By the end of the decade, in 1988, just shy of Willard Vann's twenty-year cautionary deadline, North Tulsa—which now spread north into the area beyond the Gilcrease Expressway — had a higher rate of crime than any other area in Tulsa. As Vann and other North Tulsa community leaders had predicted, by building the housing projects without incorporating economic diversity, Tulsa city planners had constructed a ghetto.

\section{Conclusion}

North Tulsa housing projects were, and still are, isolated from many of the jobs and services that people need to live happy, healthy lives. Today, the area is a food desert

\footnotetext{
${ }^{365}$ Fairchild, interview.

${ }^{366}$ Ibid.

367 Tulsa, Oklahoma Police Department, "Drug-Related Crime Problems in Public Housing."
} 
where the most accessible place for residents to buy groceries are dollar stores—of which there are six in the area. There is also a lack of jobs and adequate bus lines to get people to and from work reliably in other areas of town where there are more opportunities for employment. ${ }^{368}$ In April 2018, Tulsa planning commissioner John Dix spoke to city planners about the reason why there are not more grocery stores in North Tulsa. Dix said that it is because the high rates of crime and low employment rates in the area "make people not want to put stores over there." Dix explained, "There have been grocery stores in North Tulsa [...] most recently Las Americas [which] was open three weeks, and got robbed for $\$ 18,000$.” Dix concluded by saying that fixing problems of poverty and crime in North Tulsa is up to North Tulsans: "As soon as the community solves that one problem, you will have grocery stores in North Tulsa." ${ }^{369}$ A catch twenty-two if ever there was one. The current conditions of North Tulsa are inseparable from the waves of violences covered in this thesis - segregation at statehood, the 1921 Tulsa Race Riot, disinvestment and mid-century processes of urban renewal. In fact, they are the embodiment of the continuation of relentless violences that have eroded North Tulsa physically, economically, socially, and historically. This is a history that is not exceptional to Tulsa, but one that is instead replicated in slightly divergent forms in cities nationwide.

${ }^{368}$ Kevin Canfield, "Planning commissioner says inability to make money, attract workers keeping grocery stores out of north Tulsa: Planner cites theft, hiring issues for lack of north Tulsa grocery stores," Tulsa World, April 2, 2018. ${ }^{369}$ Ibid. 
Communities like Greenwood threatened the status quo of the established racial hierarchy in America, and local and national governments used different methods over the years to maintain the color line. Sometimes, they used overt forms of violence and racist language, while other times they employed more subtle—but no less effectiveforms. In Oklahoma and Tulsa, the white supremacist motivations behind urban renewal processes beginning in the late 1950s were much the same as those that began at the turn of the century with segregation at statehood, persisted through the TRR, and proceeded into the decades that followed with disinvestment. Processes of urban renewal—slum clearance, expressway building, and housing projects—-were part of a national program that helped facilitate Tulsa and other American cities in carrying out their own local racial agendas. In North Tulsa, they made it next to impossible for the community to maintain the culture of interdependence that had been an essential component to their success since settlement in pre-Oklahoma statehood days — something that was fundamental to the settling of Greenwood, enabled them to thrive after segregation, and rebuild after the Riot.

While segregation at statehood and the TRR were overt enactments of white supremacy, ensuing waves of violence — disinvestment, and midcentury processes of urban renewal were of a subtler, more palatable kind. With the last wave of violence, Tulsa city planners capitalized on the ravages of disinvestment by utilizing slum clearance, expressway building, and remote housing projects to control the placement and visibility of African American people in Tulsa through the sanctioned destruction of homes, the disruption, and the displacement of North Tulsa's black community further to the north of the city. This displacement is a kind of erasure - a process that combines 
omissions with historical revisionism or "mythmaking" in order to promote the narrative of those who hold the most power. ${ }^{370}$ In so doing, the city of Tulsa was able to reclaim the prime urban real estate they had long been after, but black Tulsans did not forget where they were from or what had happened there. While whites could erase and ignore the past, North Tulsa, as Michael Bates asserts "bears the mark of an officially planned and methodically executed purge," as violence is written onto the landscape. ${ }^{371}$

On June 1, 1994, a commemoration service took place at Mt. Zion Baptist Church, the culminating event for a series of activities that flanked the $75^{\text {th }}$ anniversary of the Tulsa Race Riot. In the church that day, over 1,200 Tulsans of different races and religions gathered in the hopes of beginning a healing process after the " 75 -year conspiracy of silence" that had long surrounded the TRR. Riot survivor Robert Fairchild, among others, was in attendance, and watched as Reverend Benjamin Hooks, former director of the national office of the NAACP, gave a keynote speech. He was followed by others, including such luminaries of local government as former Oklahoma Senator David Boren. Oklahoma State Representative Don Ross, who spent his youth in Greenwood, was tasked by state government officials with delivering an official apology for the Riot. ${ }^{372}$

\footnotetext{
${ }^{370}$ David Rotenstein, "Farm Road: Rural Gentrification and the Erasure of History | National Council on Public History," History @ Work, July 13, 2005, accessed May 2, 2018, http://ncph.org/history-at-work/farm-road-rural-gentrification-and-the-erasure-ofhistory/.

${ }^{371}$ Bates, "Steps to Nowhere."

${ }^{372}$ Gates, They Came Searching, 275. In 1997, Don Ross formed the Tulsa Race Riot Commission and began advocating for reparations for Riot survivors and their descendants. This was because, he explained, there is "no money in apologies." The commission was not successful in getting reparations for the survivors and their
} 
Afterwards, the crowd marched the short distance to the site of a newly erected permanent memorial in remembrance of the Tulsa Race Riot and in commemoration of Black Wall Street. There they dedicated the memorial with a flame-lighting ceremony. Eighty-eight-year-old Riot survivor and long-time member of Mt. Zion Baptist Church, Julius Williams, spoke at the event, saying "I have no hatred in my heart about what happened long ago in the riot. But I want people to take a good, hard look at that," pointing to the granite memorial, "a good hard look. I want people to realize that we have achieved so much the last seventy-five years." ${ }^{\prime 373}$ Historian and North Tulsa community member Eddie Faye Gates explained that what Mr. Williams said during the ceremony connects to something "ordinary people, especially minorities, feel in their hearts - that is that all people have a deep yearning to be listened to [...]. They need to have others respect their experiences in history and to use the cause-effect relationships of the past to explain and clarify their positions in the present, and help them sort out their expectations for the future." ${ }^{374}$ This is something, Gates asserted, that white Tulsans had long denied Tulsa's African American community "because of the conspiracy of silence regarding the race riot." ${ }^{\prime 375}$ I believe that this conspiracy of silence extends beyond the violence of the Riot into the historical omissions and vacuous silence that envelopes the other waves of violence that this thesis details.

descendants. As of 2011, Ross retired and was no longer speaking with Riot survivors. "I cut that connection," Ross said, giving the reason that "it was too heartbreaking."

${ }^{373}$ Ibid, 275-276.

${ }^{374}$ Ibid, 276.

${ }^{375}$ Ibid. 
By tracing the history of waves of violence perpetrated by white Tulsa upon Tulsa's black community, we can present an important counternarrative to myths like the ones I was told about North Tulsa as an inquisitive teenager. African Americans settled Greenwood during Jim Crow-a point at which the frequency of violence in Tulsa was at a high vibrato. They fought to save Dick Rowland, their own community, and then their land during the fever pitch of the Tulsa Race Riot of 1921. They rebuilt after the Riot, some say better than before, and weathered economic disinvestment by relying on their culture of interdependence — the community vibrant — that had long buoyed their community. Though these first three waves of violence wore away at their landscape and economy, they were able to remain in place which helped them to maintain their social ties, public memory, shared identity, and their history. The third and fourth waves, disinvestment and processes of urban renewal, were a low-hum of discordant violence that eroded and then destroyed much of the physical structures of Greenwood, breaking apart the community and displacing residents across North Tulsa. After these last waves, there was not much left to hold on to.

Displacement creates a kind of fissure in time. People are tied to place and place is the root of history, memory, and collective identity. Place and time are important in shaping memories, identity, and history and the built environment provides a scaffold for maintaining psychological and emotional heath. ${ }^{376}$ Familiar buildings and streets trigger memories, inspire curiosity, and foster a sense of community tied to a shared identity

${ }^{376}$ Dolores Hayden, The Power of Place: Urban Landscapes as Public History (Cambridge, Massachusetts: The MIT Press, 1995), 9-11. 
experienced in place. ${ }^{377}$ This relationship between person and place can serve to break down historical myths and connect people to the stories where they live. When this relationship is disrupted, so too are people's lives. ${ }^{378}$

But Tulsa's past casts a long shadow, even, perhaps especially when it is not fully acknowledged. Eddie Faye Gates explains what she refers to as the "umbilical connection to the past" shared by black Tulsans that stretches back to "a painful wrenching from their [ancestral] homeland in Africa and a no-return voyage across the deep waters of the Atlantic Ocean on a slave ship." ${ }^{\prime 379}$ Gates asserts that this legacy of trauma gave early black Pioneers the strength to survive in decades past and is embedded in the hearts of future generations, helping them to survive in "equally strange and hostile places." 380 Even though much of the landscape of Greenwood has been destroyed by the violence recounted in this thesis, black Tulsans hold close to the legacies embodied in their community. Moreover, some buildings do remain —including Mount Zion Baptist Church.

The church exists today not only as a landmark - a symbol - of the community of Greenwood's persistence to survive, but also as a vigorous cultural and religious institution. As a place, Mount Zion embodies the memory of the riot, the perseverance of the people of Greenwood, and the cultural continuity that has persisted within the

\footnotetext{
377 National Trust for Historic Preservation, "Why Do Old Places Matter?” April 24, 2015, accessed September 30, 2016, https://preservationnation.exposure.co/why-do-oldplaces-matter.

378 David E. Kyvig and Myron A. Marty, Nearby History Exploring the Past Around You, 3rd ed (Lanham, MD: Rowman \& Littlefield Publishers, 2010).

379 Gates, They Came Searching, 5.

${ }^{380}$ Gates, They Came Searching, 11.
} 
community from pre-Riot times into the present. The church building and its surrounding landscape relay the story of the people of Greenwood and of the Tulsa Race Riot. An abiding cultural and religious institution, the church offers a sense of an uninterrupted stream of time within the historically disrupted community of Greenwood. Within its now much-altered and nearly unrecognizable neighborhood, the church persists as a visual reminder of waves of violence and resistance in Greenwood. 


\section{Bibliography}

\section{Primary Sources}

\section{$\underline{\text { Newspapers }}$}

“Abuses in Public Housing Expensive for Taxpayers.” Tulsa World. March 20, 1964.

Birmingham, Tom. "Urban Renewal Has Human Side.” Tulsa World. July 30, 1966.

Buckner, George W. "Second View of City of Ruins.” St. Louis Argus. April 21, 1922.

“City Earmarks \$316,406 For Urban Renewal Cost.” Tulsa World. December 19, 1962.

“City Okays Westbank Renewal Plan.” Tulsa World. c. 1960s.

"Construction Criticized: Seminole Hills Project Given TURA Approval." Tulsa Tribune. 1967.

"Editor Smitherman Recipient of Many Letters of Commendation." Tulsa Star. August $30,1918$.

"Flogged, Tarred and Feathered: Modern Ku Klux Klan Comes into Being; Seventeen First Victims.” Morning Tulsa Daily World. November 10, 1917.

"For Action on Race Riot Peril: Radical Propaganda Among Negroes Growing, and Increase of Mob Violence Set Out in Senate Brief for Federal Inquiry." New York Times. October 5, 1919.

“Get Out The Hemp.” Tulsa World. November 9, 1917.

"HOME, SWEET HOME: Home for you and your Children. MILLIONS! Of Acres in the Cherokee Strip Soon to be Given to the People for Homes." Langston City Herald. November 17, 1892.

““Inheritance' Still Eludes Widow.” Tulsa World. C. 1960s.

“JIM CROW IS UNJUST.” Muskogee Times-Democrat. December 27, 1907.

"Look to Future with Confidence: Renewal Group Gratified with First Year's Results." Tulsa World. 1964.

"Model Cities." Tulsa World. December 8, 1967. 
"Nab Negro for Attacking Girl in an Elevator." Tulsa Tribune. May 31, 1921.

"Near Lynching at Bristow, Okla.: Cowards Failed to Lynch a Colored Man." Tulsa Star. August 24, 1918.

“Oklahoma and Indian Territory.” Langston City Herald. October 5, 1895.

Omstead, Tom. "Money Scramble Set Off As ‘Dozer Reveals Cache.” Tulsa World. c. 1960s.

"Renewal Group Gratified With First Year’s Results.” Tulsa World. March 8, 1964.

“Seminole Families Protest: Tulsa OK's Urban Renewal." Tulsa World. October 20, 1962.

“The Blacks in Oklahoma.” New York Times. April 9, 1891.

“There's Just No Accounting Of Cash Cache.” Tulsa World. c. 1960s.

Titcomb, Timothy. "It Must Not be Again.” Tulsa Tribune. June 4, 1921.

“To Lynch Negro Tonight.” Tulsa Tribune. May 31, 1921.

“TURA Gets First Check For Buying.” Tulsa World. February 28, 1963.

“TURA Still Supporting Housing Plan.” Tulsa Tribune. 1967.

"Urban Renewal Unit Picks Tulsa Firm for Seminole Hills Survey." Tulsa Tribune. February 2, 1961.

"Wooton Lists Most Needed City Projects: Expressways, Streets, Sewers, City Hall Are Among 24 Priority Jobs." Tulsa Tribune. July 26, 1957.

\section{$\underline{\text { Magazines }}$}

Comstock, Amy. “Another View of the Tulsa Riots." Survey. July 2, 1921.

Du Bois, W.E.B. “Returning Soldiers.” The Crisis. XVIII. May 1919.

“Mob Fury and Race Hatred as a National Danger." The Literary Digest. June 18, 1921.

“Tulsa, the Future Metropolis.” Sturm's Statehood Magazine. Vol.1, No. 1. September 1905. 
Wheeler, Ed. "It Happened in Tulsa." Impact Magazine. June-July edition, 1971.

White, Walter F. "The Eruption of Tulsa." The Nation, June 29, 1921.

\section{$\underline{\text { Government Documents }}$}

Grand Jury Report. Final Report of the Tulsa Grand Jury. Oklahoma State University Tulsa Special Collections and Archives. Ruth Sigler Avery Tulsa Race Riot Archive. Series 2, Research Box 6.

L.A. Brown of Civil and Criminal Investigations, Kansas City, Missouri, to Roger Baldwin of the National Civil Liberties Bureau. New York, New York. March 25, 1918. http://thislandpress.com/wp-content/uploads/2013/07/labrown.jpg.

"Report on Vice Conditions in Tulsa, 1921 May 18." Box 25, Record Group 1-2. State of Oklahoma vs. John A. Gustafson, Chief of Police Tulsa. Tulsa Race Riot Investigation Vice Condition, Civil Case No. 1062. Attorney General. Oklahoma State Archives Division, Oklahoma Department of Libraries. Oklahoma City, OK.

State of Oklahoma vs. Dick Rowland. Case No. 2239. Tulsa County District Court. June $18,1921$.

Tulsa Metropolitan Area Planning Commission. "Metropolitan Tulsa Program For Community Renewal: General Development Plan.” Tulsa City-County Library Archives. Tulsa, Oklahoma, 1963.

Tulsa, Oklahoma Police Department. "Drug-Related Crime Problems in Public Housing." The Problem-Oriented Approach to Drug Enforcement. Bureau of Justice. Police Executive Research Forum. June 1, 1989. http://www.popcenter.org/library/unpublished/CaseStudies/131_Problem_Oriente d_Approach to_Drug_Enforcement_Four_Case_pdf.

$\underline{\text { Interviews }}$

Bate, Dr. Charles. Interviewed by Cherie Poyas. May 6, 1980. Junior League of Tulsa. Tulsa City-County Library. http://cdm15020.contentdm.oclc.org/cdm/ref/collection/p15020coll10/id/140

Fairchild, Robert L. Interviewed by Scott Ellsworth. June 8, 1978. Duke University Oral History Program, box 2. Rubenstein Library and University Archives, Durham, North Carolina. 
Jones, Mozella Franklin. Interviewed by Carol Minshall. January 16, 1980. Junior League of Tulsa Oral History Interviews. Tulsa City-County Library, Tulsa, Oklahoma. http://cdm15020.contentdm.oclc.org/cdm/ref/collection/p15020coll10/id/569/.

Holoway, W.R. Interviewed by Tulsa Historical Society Oral History Program. Tulsa Historical Society Oral History Collection. https://soundcloud.com/user-604183945/wr-holway-interview.

Misch, Fannie. Interviewed by Tulsa Historical Society Oral History Program. Tulsa Historical Society Oral History Collection. https://soundcloud.com/user-604183945/fannie-misch-interview.

$\underline{\text { Books }}$

Franklin, Buck Colbert. My Life and an Era: The Autobiography of Buck Colbert Franklin. Louisiana State University Press, 1997.

Parrish, Mary E. Jones. Events of the Tulsa Disaster. Tulsa, Oklahoma: University of Tulsa. McFarlin Library, Department of Special Collections, 1922. http://cdm15887.contentdm.oclc.org/cdm/ref/collection/p15887coll1/id/129.

Thompson, Don. Hush, Somebody's Callin' My Name: A Photographic Essay of Survival, Resilience and Perseverance. Tulsa, Oklahoma: Holbrook Printing Company, 2008.

$\underline{\text { Archives }}$

Carlson, I. Marc, “Tulsa Race Riot of 1921 archive, 1920 - 2007," University of Tulsa McFarlin Library Catalog, available online at http://library.utulsa.edu/record=b1258210 (accessed on October 23, 2015).

"Ruth Sigler Avery Tulsa Race Riot Archive." Oklahoma State University Tulsa Special Collections and Archives.

Tulsa City-County Library Archives, Tulsa, Oklahoma.

“Tulsa Race Riot, 1921 Oral History Collection," Rubenstein Library and University Archives, Duke University, Durham, North Carolina.

Poetry

Smitherman, A.J. “A Descriptive Poem of the Tulsa Race Riot.” 1922. Accessed on April 
8, 2018.

http://www.personal.utulsa.edu/ marc-carlson/riot/smithermanpoem.html.

Map

Home Owners Loan Corporation. Tulsa Security Map. Exact date unknown. Map held in possession of author.

$\underline{\text { Unpublished work }}$

Hall, Ina. "North Tulsa." Ruth Sigler Avery Tulsa Race Riot Archive. Oklahoma State University Tulsa Special Collections and Archives. Series 2, Research Box 6.

\section{Secondary Sources}

Books

Amato, Joseph. Rethinking Home: A Case for Writing Local History. University of California Press, 2002. Kindle edition.

Ammon, Francesca Russello. Bulldozer: Demolition and Clearance of the Postwar Landscape. New Haven: Yale University Press, 2016. Kindle edition.

Anthony Sellers, Nigel. Oil, Wheat, and Wobblies: The Industrial Workers of the World in Oklahoma, 1905-1930. University of Oklahoma Press, 1998.

Biles, Roger. From Tenements to the Taylor Homes: In Search of an Urban Housing Policy in Twentieth-Century America. Penn State Press, 2010.

Brophy, Alfred L. Reconstructing the Dreamland: The Tulsa Riot of 1921: Race, Reparations, and Reconciliation. Oxford University Press, 2002. Kindle edition.

Ellsworth, Scott. Death in a Promised Land: The Tulsa Race Riot of 1921. Baton Rouge: Louisiana State University Press, 1982. Kindle edition.

Franklin, Jimmie Lewis. The Blacks in Oklahoma. Norman, Oklahoma: University of Oklahoma Press, 1980.

Gates, Eddie Faye. They Came Searching: How Blacks Sought the Promised Land in Tulsa. Austin, Texas: Eakin Press, 1997. 
------. Riot on Greenwood: The Total Destruction of black Wall Street, 1921. Fort Worth, TX: Eakin Press, 2003.

Gordon, Linda. The Second Coming of the KKK: The Ku Klux Klan of the 1920s and the American Political Tradition. Liveright Publishing, 2017. Kindle edition.

Hayden, Dolores. The Power of Place: Urban Landscapes as Public History. Cambridge, Massachusetts: The MIT Press, 1995.

Hirsch, James. Riot and Remembrance: The Tulsa Race War and Its Legacy. Houghton Mifflin Company, 2002. Kindle edition.

Hower, Bob. Ed. 1921 Tulsa Race Riot and the American Red Cross, "Angels of Mercy." Tulsa, Oklahoma: Homestead Press, 1993.

Jackson, Kenneth T. Crabgrass Frontier: The Suburbanization of the United States. Oxford University Press, 1987. Kindle edition.

Jacoby, Karl. Shadows at Dawn: An Apache Massacre and the Violence of History. New York, New York: Penguin Books, 2008.

Johnson, Hannibal. black Wall Street: From Riot to Renaissance in Tulsa's Historic Greenwood District. Austin, Texas: Eakin Press, 1998. Kindle edition.

Kyvig, David E. and Myron A. Marty. Nearby History Exploring the Past Around You. 3rd ed. Lanham, Maryland: Rowman \& Littlefield Publishers, 2010.

Massey, Douglas and Nancy Denton. American Apartheid: Segregation and the Making of the Underclass. Boston: Harvard University Press, 1993.

McWhirter, Cameron. Red Summer: The Summer of 1919 and the Awakening of black America. New York: Henry Holt and Company, 2011.

Morgan, David R. Oklahoma Politics \& Policies: Governing the Sooner State. University of Nebraska Press, 1991.

Portelli, Alessandro. The Order Has Been Carried Out: History, Memory, and Meaning of a Nazi Massacre in Rome. New York: Palgrave Macmillan, 2003.

Rothstein, Richard. The Color of Law: A Forgotten History of How Our Government Segregated America. New York, London: Liveright Publishing Corporation, 2017.

Satter, Beryl. Family Properties: Race, Real Estate, and the Exploitation of black Urban America. New York: Henry Holt and Company, 2010. 
Walker, Robin. The Rise and Fall of black Wall Street. Reklaw Education, 2010. Kindle edition.

Williams, Chad L. Torchbearers of Democracy: African American Soldiers in the World War I Era. University of North Carolina Press, 2010.

Journal articles

Bailey, Merrill Jean. "Redefining the Baptist Training Union in African American Churches." The Journal of the Interdenominational Theological Center. Vol. 40. No. 1 (Fall 2014).

Dann, Martin. "From Sodom to the Promised Land: E.P. McCabe and the Movement for Oklahoma Colonizaton." Kansas Historical Quarterly, Vol. XL, No. 3 (Autumn 1974). http://www.kancoll.org/khq/1974/74_3 dann.htm.

Farrar, Margaret E. "Amnesia, Nostalgia, and the Politics of Place Memory." Political Research Quarterly 64 (2011).

Fullilove, Mindy Thompson and Rodrick Wallace. "Serial Forced Displacement in American Cities, 1916-2010." Journal of Urban Health: Bulletin of the New York Academy of Medicine, 88:3 (2011).

Gotham, Kevin Fox. "Urban Space, Restrictive Covenants and the Origins of Racial Residential Segregation in a US City, 1900-50." International Journal of Urban and Regional Research, 24:3 (September 2000).

O'Dell, Larry. "Andrew J. Smitherman, the Tulsa Star, and the Tulsa Race Riot of 1921." The Chronicles of Oklahoma. Oklahoma Historical Society, 2002.

Robertson, Jere W. "Edward P. McCabe And The Langston Experiment." The Chronicles of Oklahoma. Oklahoma Historical Society, 1973.

SimmsParris, Michele M. "What Does it Mean to See a black Church Burning? Understanding the Significance of Constitutionalizing Hate Speech." University of Pennsylvania Journal of Constitutional Law (Spring 1998).

\section{Newspapers}

Canfield, Kevin. "Planning commissioner says inability to make money, attract workers keeping grocery stores out of north Tulsa: Planner cites theft, hiring issues for lack of north Tulsa grocery stores.” Tulsa World. April 2, 2018. 
Jones, F. “96-Years Later, The Greenwood Cultural Center 1921 Race Riot Massacre Facts With Video.” The Oklahoma Eagle. June 1, 2017.

"Remembering when the Sky Rained Death: 95-Year-Old-Women Recalls Race Riot." Tulsa World. May 18, 1994.

“Ruth Avery-Parker, Race Riot Historian, Dies.” Tulsa World. November 6, 2001.

Rutherford, Dan. "The Glory of Greenwood.” Tulsa World. March 10, 1997.

Magazines:

Bates, Michael D. "Steps to Nowhere.” This Land Press. June 18, 2014.

Chapman, Lee Roy. "The Nightmare of Dreamland." This Land Press. April 18, 2012.

Gerkin, Steve. "First Charged, Last Freed." This Land Press. March 20, 2014.

\section{$\underline{\text { Online sources }}$}

Black Wall Street, USA. “O.W. Gurley: The Visionary Builder.” Accessed May 11, 2018. http://www.blackwallstreet.org/owgurly.

Carlson, I. Marc. "Timeline of the Tulsa Race Riot." The Tulsa Race Riot of 1921. Last modified July 18, 2012.

http://www.personal.utulsa.edu/ marc-carlson/riot/tulsatime.html.

Equal Justice Initiative. "Lynching in America: Targeting black Veterans." Accessed March 16, 2018. https://eji.org/reports/online/lynching-in-america-targeting-black-veterans.

Franklin, Jimmie Lewis. "African Americans." The Encyclopedia of Oklahoma History and Culture. Accessed February 12, 2018.

http://www.okhistory.org/publications/enc/entry.php?entry=AF003.

Gregory, Carl E. "Tulsa.” The Encyclopedia of Oklahoma History and Culture. Accessed February 12, 2018.

http://www.okhistory.org/publications/enc/entry.php?entry=TU003.

Hoig, Stan. "Land Run of 1889." The Encyclopedia of Oklahoma History and Culture. Accessed January 2, 2018.

http://www.okhistory.org/publications/enc/entry.php?entry=LA014. 
Library of Congress. "About the Langston City Herald (Langston City, O.T. [Okla]), 1891-1902." Chronicling America: Historic American Newspapers. Accessed March 21, 2018. http://chroniclingamerica.loc.gov/lccn/sn83025050/.

National Trust for Historic Preservation. "Why Do Old Places Matter?" April 24, 2015. https://preservationnation.exposure.co/why-do-old-places-matter.

O'Dell, Larry. "Ku Klux Klan." The Encyclopedia of Oklahoma History and Culture. Accessed April 8, 2018. http://www.okhistory.org/publications/enc/entry.php?entry=ku001.

-------. "Smitherman, Andrew J." The Encyclopedia of Oklahoma History and Culture. Accessed February 23, 2018. http://www.okhistory.org/publications/enc/entry.php?entry=SM008.

Rotenstein, David. "Farm Road: Rural Gentrification and the Erasure of History | National Council on Public History." History @ Work. July 13, 2005. http://ncph.org/history-at-work/farm-road-rural-gentrification-and-the-erasure-ofhistory/.

Shabazz, Alimcar. "Smitherman, A.J. (1883-1961)." Blackpast.org. Accessed May 14, 2018.

http://www.blackpast.org/aaw/smitherman-andrew-j-1883-1961.

Tulsa County Library. "What is the meaning of the name 'Tulsa'?" Local/Municipal Government: Tulsa Area FAQs. Accessed January 5, 2018. http://guides.tulsalibrary.org/c.php?g=695427\&p=4931218\#9395804.

Tulsa County Library. "Tulsa and Oklahoma History in the Research Center: Tulsa Timeline.” Accessed January 5, 2018. http://guides.tulsalibrary.org/c.php?g=695416\&p=4931569.

Veenendaal Jr., Augustus J. "St. Louis and San Francisco Railway." The Encyclopedia of Oklahoma History and Culture. Accessed March 28, 2018. http://www.okhistory.org/publications/enc/entry.php?entry=ST009.

Virginia Commonwealth University. "Jim Crow Laws and Racial Segregation." VCU Libraries Social Welfare History Project. Accessed January 3, 2018. https://socialwelfare.library.vcu.edu/eras/civil-war-reconstruction/jim-crow-lawsandracial-segregation/.

Whitney Plantation. "Slave Trade in Louisiana: Naming Practices." Accessed February 15, 2018. http://whitneyplantation.com/naming-practices.html.

World Heritage Encyclopedia. "Booker T. Washington High School (Tulsa).” Accessed 
February 17, 2018.

http://newspaperslibrary.org/articles/eng/Booker_T. Washington_High_School_(

$\underline{\text { Tulsa). }}$.

Government documents

National Archives. “Oklahoma Statehood, November 16, 1907.” Center for Legislative Archives. Featured Congressional Documents. Accessed May 11, 2018. https://www.archives.gov/legislative/features/oklahoma.

Ross, Don, et al. Tulsa Race Riot: A Report by the Oklahoma Commission to Study the Tulsa Race Riot of 1921. Oklahoma Commission to Study the Tulsa Race Riot of 1921. Oklahoma: 2001. Accessed May 5, 2018.

http://www.okhistory.org/research/forms/freport.pdf.

U.S. Department of Agriculture (USDA). "Economic Research Service.” Updated May 18, 2017. Accessed May 3, 2018. https://www.ers.usda.gov/data-products/food-access-research-atlas/go-to-theatlas/.

U.S. Department of the Interior. National Park Service. Final 1921 Tulsa Race Riot Reconnaissance Survey. November 2005.

U.S. Department of the Interior. National Park Service. National Register of Historic Places Form: Mount Zion Baptist Church. By Cathy Ambler, PhD. NPS 10-900. Tulsa, OK. April 2005.

Theses and dissertations

Carlson, I. Marc. “The Tulsa Race Riot of 1921.” Bachelor's Thesis, Oklahoma State University, 1989.

Cayton, Leonard B. "A History of black Public Education in Oklahoma." PhD diss., University of Oklahoma, 1977.

Gill, Loren L. “The Tulsa Race Riot.” M.A. thesis, University of Tulsa, 1946.

\section{$\underline{\text { Lecture }}$}

Portelli, Alessandro. "Myth, Memory, and Trauma: Intergenerational Transmission of Stories of the Fosse Ardeatine Massacre in Rome." Filmed lecture for Columbia 
University's Oral History Master of Arts Program, June 12, 2017.

https://www.youtube.com/watch? $v=\mathrm{cmK} 3$ ScrE5eI\&t=1022s. 


\section{Appendix}

Tulsa Population by Race 1900-1980

\begin{tabular}{|c|c|c|c|c|c|c|c|c|c|}
\hline Race & 1900 & 1910 & 1920 & 1930 & 1940 & 1950 & 1960 & 1970 & 1980 \\
\hline $\begin{array}{c}\text { Whit } \\
\text { e }\end{array}$ & NA & $\begin{array}{c}30,860 \\
(88.184 \\
\%)\end{array}$ & $\begin{array}{c}97,072 \\
(89.038 \\
\%)\end{array}$ & $\begin{array}{c}166,056 \\
(88.528 \\
\%) \\
\end{array}$ & NA & NA & $\begin{array}{c}314,170 \\
(90.791 \\
\%) \\
\end{array}$ & $\begin{array}{c}354,915 \\
(88.361 \\
\%) \\
\end{array}$ & $\begin{array}{c}400,000 \\
(85.11 \\
\%)\end{array}$ \\
\hline $\begin{array}{c}\text { blac } \\
\mathbf{k}\end{array}$ & NA & $\begin{array}{c}2,754 \\
(7.87 \%)\end{array}$ & $\begin{array}{c}10,903 \\
(10.001 \\
\%) \\
\end{array}$ & $\begin{array}{c}17,817 \\
(9.499 \%)\end{array}$ & NA & NA & $\begin{array}{c}26,819 \\
(7.75 \%)\end{array}$ & $\begin{array}{c}35,244 \\
(8.775 \%)\end{array}$ & $\begin{array}{c}43,647 \\
(9.275 \\
\%) \\
\end{array}$ \\
\hline $\begin{array}{c}\text { Othe } \\
\mathbf{r}\end{array}$ & NA & $\begin{array}{c}1,381 \\
(3.946 \%)\end{array}$ & $\begin{array}{c}1,048 \\
(0.961 \%)\end{array}$ & $\begin{array}{c}3,701 \\
(1.973 \%) \\
\end{array}$ & NA & NA & 5,049 & $\begin{array}{c}11,504 \\
(2.864 \%) \\
\end{array}$ & 26,423 \\
\hline Total & $\frac{1,39}{\underline{0}}$ & 34,995 & 109,023 & 187,574 & $\frac{193,69}{\underline{3}}$ & $\frac{251,68}{\underline{6}}$ & 346,038 & 401,663 & 470,593 \\
\hline
\end{tabular}

381 "Oklahoma Counties and Places: Decennial Populations, 1890-2010," Oklahoma Department of Commerce, accessed April 27, 2018, https://www.google.com/url? sa $=$ t\&rct=j\&q=\&esrc $=$ s\&source $=$ web \&cd $=23 \& v e d=0$ ahUK EwjOn4jzxq7ZAhUG9mMKHcIcCsgQFgixATAW\&url=http\%3A\%2F\%2Fokcommerce .gov $\% 2$ Fassets $\% 2$ Ffiles $\% 2$ Fdata-and-research $\% 2$ Fdecennialcensus\%2F1890_2010_Decennial_Census_Population_by_Place_by_County.xlsx\&usg= AOvVaw1Eq3b-Do93J4WD554WZF04

I was unable to find racial breakdowns for years 1900, 1940, and 1950. 
Tulsa Home Owners Loan Corporation Residential Security Map

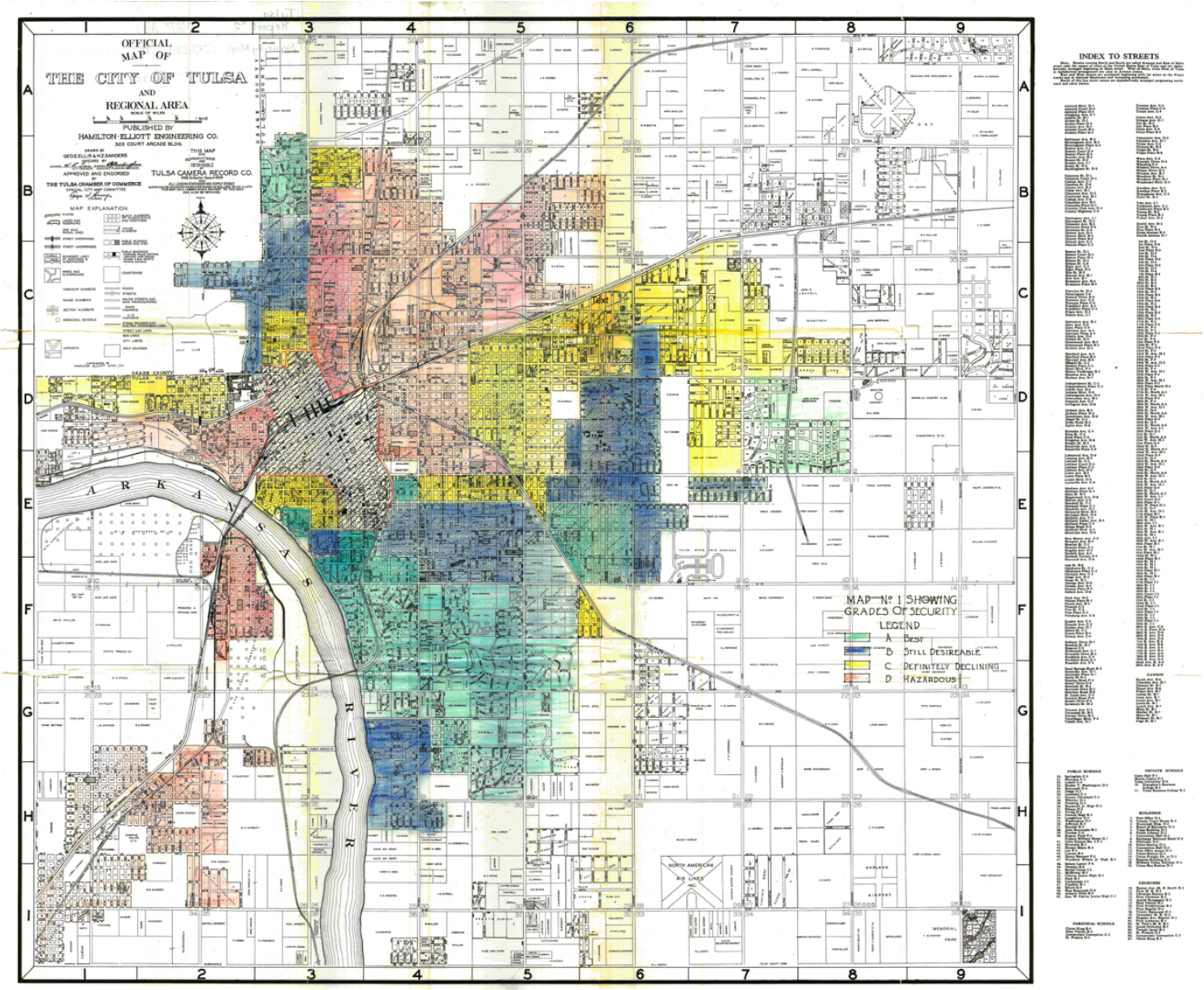




\section{Housing Projects in Relation to Historic Greenwood}

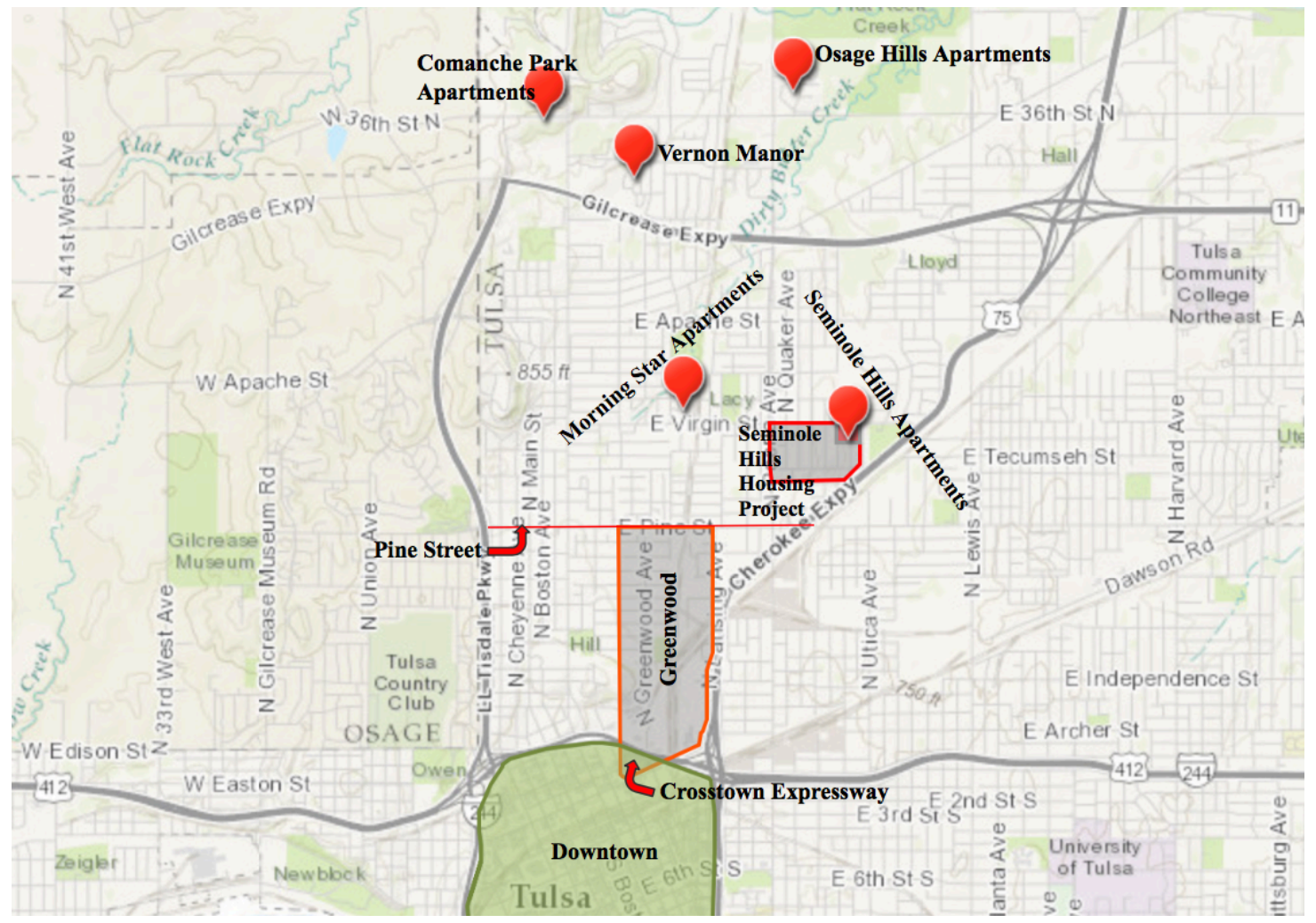

